\title{
Shackled to the Soil: The Long-Term Effects of Inherited Land on Labor Mobility and Consumption
}

\author{
A. Nilesh Fernando *
}

December 8, 2015

\begin{abstract}
Productive assets promote the economic well-being of the rural poor in the developing world. However, in a context where market frictions limit their exchange and such assets come bundled with cultural obligations, they may instead restrict access to high-return economic opportunities and cause a microeconomic parallel to the 'resource curse'. Using an instrumental variables strategy and variation arising from sibling sex composition and Hindu inheritance customs that favor sons, I test this hypothesis by estimating the long-term causal effect of inheriting agricultural land in rural India. Consistent with standard models, inheriting land facilitates borrowing and increases household consumption. Yet, where the ability to fully utilize land through markets is constrained by cultural obligations or land market transaction costs, the effect on consumption is entirely attenuated and negative for those who inherit at an early age. Those who inherit land are significantly less likely to migrate to urban areas and enter non-agricultural work in rural areas. These findings suggest that inheriting land greatly influences occupational trajectories and can suppress household consumption to an extent that may overwhelm its direct benefit.
\end{abstract}

JEL Classification Numbers: O12, J24, C26, J62.

Keywords: Structural Transformation, Agriculture, Factor Market Frictions, Inherited Assets, Culture

*Postdoctoral Fellow, Department of Economics, Harvard University, Cambridge, MA (afernando@fas.harvard.edu). I am indebted to my advisors: Asim Khwaja, Shawn Cole, Lawrence Katz and Richard Hornbeck for their guidance on this project. I would also like to thank Josh Angrist, Zac Apte, James Boyce, Raj Chetty, Bill Clark, Raissa Fabregas, Rema Hanna, Lakshmi Iyer, Supreet Kaur, Michael Kremer, John Marshall, Janhavi Nilekani, Nathan Nunn, Rohini Pande, Daria Pelech, Tarun Pokiya, Niharika Singh, Anitha Sivasankaran, Jeremy Tobacman and participants of the Harvard Development Lunch Public Finance/Labor Lunch, Political Economy Lunch and HKS Sustainabilty Science Seminar for numerous helpful comments. I thank Andrew Foster and the National Council for Applied Economic Research (NCAER) for sharing data. Finally, I thank Alexander Gorzewski and Tarun Pokiya for outstanding research assistance. I acknowledge support from the Sustainability Science Program at the Harvard Kennedy School. All errors are my own. 


\section{Introduction}

"I see young men, my townsmen, whose misfortune it is to have inherited farms ... ; for these are more easily acquired than got rid of. Who made them serfs of the soil?"

- Henry David Thoreau, Chapter 1, Walden, 1854

Asset endowments expand access to economic opportunity. Conventional models of poverty traps predict that initial endowments may ease borrowing constraints and allow the rural poor to take advantage of high-return opportunities outside agriculture (Banerjee and Newman, 1993; Galor and Zeira, 1993). ${ }^{1}$ In so doing, assets may facilitate the process of 'structural transformation' predicted by influential theories of economic development (Lewis, 1954; Harris and Todaro, 1970) that is borne out by the recent empirical literature. ${ }^{2}$ However, in a context with multiple market imperfections, individuals maybe unable to sell, rent or leave behind such assets resulting in restrictions on their spatial and occupational mobility. As a consequence, assets may have no effect or even reduce the level of household consumption: a microeconomic parallel to the 'resource curse' hypothesis (Auty, 1993). ${ }^{3}$

I test the latter hypothesis in the context of inheriting agricultural land in rural India. Agricultural land is among the most important assets to the rural poor in the developing world. While comparative data on the means of land acquisition in developing countries is sparse, a wide range of research suggests that much agricultural land among small holders continues to be inherited rather bought. ${ }^{4}$ In this context, inherited land may come bundled or interact with cultural obligations that together with limited markets may greatly restrict how it is utilized. Using a dataset spanning 16 Indian states, I estimate the long-term causal

\footnotetext{
${ }^{1}$ Recent evidence suggests that value-added in the agricultural sector is less than half of that in the nonagricultural sector across 100 developing countries, leading the authors to conclude that labor is 'greatly misallocated' in these countries (Gollin et al., 2014)

${ }^{2}$ Experimental and non-experimental evidence shows that asset transfers allow the poor to attain a higher level of consumption and may in addition support entry into the non-agricultural sector (Besley and Burgess, 2000 ;Bandiera et al., 2011; Blattman et al., 2013)

${ }^{3}$ Auty (1993) argues that countries reliant on natural resource wealth are less able to diversify industrial production, restricting production in sectors in which they may development a comparative advantage and limiting growth relative to countries with less resource wealth.

${ }^{4}$ For example, in Africa, see: Lambert et al. (2014);Fors et al. (2015), in South Asia, see Agarwal (1994), and for states governed by Islamic inheritance law Kuran (2012). In the sample being considered, $82 \%$ of land owners inherited land.
} 
effect of inheriting agricultural land on the occupational and spatial mobility of labor and on household consumption. My identification strategy leverages a custom among Hindu families that results in sons inheriting equal shares of their parents' land. Conditional on the number of siblings an individual has and their parents' landholdings, sibling sex composition serves as an instrument for inherited land. I find that an additional brother reduces the amount of land inherited by more than an acre, or one-third of median landholdings in rural India.

In contrast to theories emphasizing the importance of initial endowments in the context of credit constraints, I find that 14 years later (median) inheriting land both restricts migration to urban areas (-0.02\% per acre) and reduces the likelihood of entering non-agricultural work in rural areas (-1.8\% per acre), even though it eases borrowing constraints. ${ }^{5}$ However, these estimates mask substantial non-linearities: the point estimates are more than ten times as large (-3.4\% per acre for migration; -21\% per acre for non-agricultural occupation) for smaller inheritances that are below the median of the land distribution (3 acres). Inheriting land increases household consumption on average (2.7\% per acre) but where a cultural obligation and land market frictions limit the ability to fully utilize land through markets, it has no effect on consumption and, among those inheriting at an early age, the effect is negative.

The cultural obligation in question requires that the eldest son in a Hindu family support his parents in their old age, often resulting in the expectation of occupational succession. In contrast to their latter-born counterparts, inheriting land is even more likely to restrict urban migration and entry into non-agricultural work for first-born sons. ${ }^{6}$ While the household consumption of later-borns increases by $3 \%$ for each acre inherited, for first-borns the effect of inheriting land is indistinguishable from zero. The implied loss in consumption resulting from this friction is almost $9 \%$ for a median inheritance. ${ }^{7}$ Furthermore, the importance of this cultural obligation persists across generations: I find that the probability of a first-born child migrating is decreasing in their parents' landholdings.

Transaction costs are another important friction limiting participation in land markets

\footnotetext{
${ }^{5}$ Specifically, inheriting an additional acre increases the probability of taking out a loan in the last five years by $1.5 \%$ and the value of loans by $15.2 \%$.

${ }^{6}$ I use 'first-born' to refer to respondents who are the first-born son in their family and 'latter-born' to refer to all other sons.

${ }^{7}$ This consumption loss also allows me to bound the size of any non-pecuniary benefit a first-born would need to experience from complying with this obligation to leave their welfare comparable to that of latter borns.
} 
across rural India. Across multiple measures of village-level transaction costs in the market for land, I find that inheriting land in villages with higher transaction costs leads to a significantly larger effect on persisting in agriculture and attenuates the consumption benefits of inheriting land.

Collectively, these results highlight the competing effects of inherited land on consumption and the mechanisms through which they operate. Inheriting land has the expected wealth effect that leads to an increase in consumption. However, where cultural obligations and frictions are salient, inheriting land limits the occupational and spatial mobility of inheritors thereby restricting access to high-return opportunities. This 'shackling' effect of land is also dynamic in nature: first-borns inheriting at an earlier age are even more likely to remain in agriculture, and their level of consumption is decreasing in the extent of inherited landholdings. The balance of these effects determine the overall effect of inheriting land on consumption.

I conduct a series of robustness tests to address identification concerns. A selection issue arises from unobserved family migration to urban areas. While this form of migration is considered very rare in rural India, I perform simulations which show that the reduced form results are robust to selective migration. In support of the conditional independence assumption of the instrument, I show that outcomes which precede the inheritance of land - including individual and parent characteristics - are not correlated with the instrument. Additionally, I show that the main estimates are robust to a number of controls intended to account for son-preferring fertility behavior including sex selective abortion, differential care and differential stopping rules.

The independent effects of sibling sex composition on human capital acquisition and dowry payments present another threat to identification. Areas with historically matrilineal inheritance customs serve as a placebo test as they should have a weaker first stage but any other effects of sibling sex composition should still influence the outcomes under consideration. Reassuringly, the reduced form effects in these areas are significantly different from areas with patrilineal inheritance customs. Similarly, I find no reduced form effects of sibling sex composition on the main outcomes of interest for individuals whose parents were landless - individuals who cannot, by definition, inherit land. In each of these cases, I also show that 
the first stage for alternative causal channels - human capital and dowry payments - does not vary significantly across these contexts.

This paper primarily contributes to a literature seeking to understand the frictions and barriers that restrict the movement of labor across sectors in the developing world. A recent essay on the contributions of the Lewis model notes that such frictions, particularly as they relate to other factor markets, are poorly understood (Gollin, 2014). Other contributions in this literature focus on barriers in credit, insurance, information and transportation that restrict the allocative efficiency of labor markets (Blattman et al., 2013 ; Bianchi and Bobba, 2012 ; Bryan et al., 2011 ; Gollin and Rogerson, 2010). This paper complements these findings by looking at frictions in land and labor markets and providing evidence of long-term effects by examining occupational transitions over more than a decade.

Second, this paper highlights the importance of asset specificity in anti-poverty programs and informs the debate on land reform. ${ }^{8}$ Relatively illiquid assets such as cattle or land are often the focus of anti-poverty programs and some, such as large-scale targeted 'ultra poor' programs in Bangladesh, may even require that beneficiaries do not liquidate their assets (Das et al., 2013). These assets may still serve as collateral in the presence of credit constraints, but the inability to easily sell the asset may constrain rather than support occupational transitions thereby harming household consumption. To this point, Das et al. (2013) find that transfers of cattle to women in 'ultra-poor' households in Bangladesh constrain their ability to work outside the household. Using the same dataset, Gulesci (2012) finds that this program has general equilibrium effects on the wage rates of non-beneficiary households.

Third, these findings are consistent with a literature estimating how changes in land markets influence labor supply. In particular, Chernina et al. (2013) find that titling reforms in Russia that enabled the sale of previously communally owned land supported internal migration by easing credit constraints, while ? find that land market restrictions influence the spatial pattern of wages. These findings are also consistent with the literature on titling

\footnotetext{
${ }^{8} \mathrm{~A}$ survey of research on land markets concludes that estimates of their welfare effects are inhibited by identification challenges resulting from the non-random assignment of land and a lack of longitudinal data (Deininger and Feder, 2001).

Recent work uses 19th century land lotteries in the US state of Georgia to estimate the causal effect of land, but the authors are unable to evaluate the impact on measures of household consumption for lack of data (Bleakley and Ferrie, 2010;Bleakley and Ferrie, 2013).
} 
in land markets, where reductions in transaction costs allow for the efficient reallocation of labor across space (Field, 2007; De Janvry et al., 2012). Similarly, Wang (2012) finds that property reform in China allowing state employees to purchase homes at a subsidized price lead to increased job mobility through entrepreneurship.

Finally, this paper contributes to an understanding of the connection between the allocative efficiency of labor markets and inherited assets. Lambert et al. (2014) finds that land bequests have important effects on sector of activity in Senegal but are not as important as parent's education. While the context and the part of the distribution of wealth under consideration differ greatly to Piketty (2014), the findings are a corollary of his examination of the intergenerational transmission of advantage. In this case, as a consequence of the fact that the assets bequeathed by parents are illiquid rather than liquid, inheritors may be inadvertently made worse off in the future. However, in both cases, the implication is that inherited assets may influence the allocative efficiency of labor markets.

The next section provides context on the inheritance of land and land markets in rural India. Section 3 motivates the empirical strategy with a conceptual framework. Section 4 describes the data sources used in the empirical analysis. Section 5 describes the empir-

ical strategy, while Section 6 presents the results from this analysis. Section 7 discusses heterogeneity in the results and the mechanisms underlying the observed effects. Section 8 describes robustness checks that test the validity of the identifying assumptions of the empirical strategy. Section 9 concludes.

\section{Context: Agricultural Land in Rural India}

\subsection{Customs and Laws Governing the Inheritance of Agricultural Land}

The majority of Hindu communities throughout rural India are characterized by patrilineal land inheritance customs. The ethnographic literature suggests that such customs largely hold sway over recent progressive reforms - in many cases agricultural land is exempt from such reforms - and continue to restrict the ability of women to inherit agricultural land. 
To this point, in her exhaustive study of gender and land rights in India, Agarwal (1994) concludes that women seldom inherit land. ${ }^{9}$ However, the north eastern states of India and the southern state of Kerala are an exception where matrilineal inheritance customs continue to be more prevalent. ${ }^{10}$

In patrilineal areas, agricultural land is typically inherited after the death of the father, with sons inheriting equal shares of their father's land. ${ }^{11}$ While recent reforms to the Hindu Succession Act have sought to give women equal claims to land, data I collected from 1,037 landed households engaged in agriculture in the western Indian state of Gujarat supports equal division and continued primacy of custom over law. ${ }^{12}$ Among these respondents, $82 \%$ described standard practice as equal division among male sons while $15 \%$ claimed all siblings inherited equal amounts (See Appendix A2.1).

\subsection{Land Markets in Rural India}

Deininger et al. (2009) suggest that both micro studies focusing on collections of villages and nationally representative datasets point to very limited participation in sales and rental markets for agricultural land in rural India. ${ }^{13}$ Similarly, Skoufias (1995) uses ICRISAT data in India to show that $75 \%$ of households are unable to meet their 'desired cultivated area' predicted landholdings based on livestock and family labor endowments - using land markets. Reasons for limited market participation in India include rental restrictions (Deininger et al.,

\footnotetext{
${ }^{9}$ In particular, she states: "Ethnographic information, although it is extremely fragmentary, consistently indicates that women in traditionally patrilineal communities of South Asia rarely realize the rights that contemporary laws have promised them. Custom still dominates practice. Hence the vast majority of women do not inherit landed property as daughters, most dont do so even as widows and few women inherit in other capacities. To the extent women inherit is usually under very restricted conditions." ((Agarwal, 1994))

${ }^{10}$ The north eastern states include Assam, Arunachal Pradesh, Manipur, Mizoram, Sikkim, Tripura and Meghalaya

${ }^{11}$ Foster and Rosenzweig (2002), in the their study of rural household division, also suggest that equal division among sons is the norm. Technically, inheritance claims extend to four generations of agnates, implying that grandsons also have a claim upon birth. In practice these shares are typically claimed and registered after the more senior member in the agnatic line dies.

12 The Hindu Succession Act (HSA) of 1951 sought to unify differing legal traditions deriving from Shastric texts but fell short of giving both sons and daughters equal claims to ancestral property. Amendments were made to the HSA by Kerala (1976), Andhra Pradesh (1986) and Tamil Nadu (1989) to enable women to have equal inheritance rights.

${ }^{13}$ In the dataset used for the majority of the empirical analysis below, over a 20 -year period $7.34 \%$ of households sold land and $13.6 \%$ bought land. In the past year, $2.89 \%$ of households leased in land, $8.63 \%$ leased out land, $4.89 \%$ engaged in any type of sharecropping and just $0.4 \%$ of the sample mortgaged their land.
} 
2008), regulatory restrictions preventing the sale of land for non-agricultural purposes and high stamp duties on land transactions (Morris and Pandey, 2007).

Generic land market imperfections include poorly defined property rights resulting in uncertainty over ownership claims (Deininger and Goyal, 2012) and information asymmetries in assessing quality of land and effort of tenants (Deininger and Feder, 2001). An important barrier to land sales and rental - of particular consequence to this paper - is a desire for farmers to continue in the tradition of their ancestors (Jodhka, 2006). While the latter study focuses on the Indian state of Punjab, a survey of landed adults aged 18-30 across 13 states in rural India (Sharma, 2007) found that $60 \%$ of respondents had no intention of selling their land, with $34 \%$ suggesting that farming was a 'mark of their identity' and they would like their children to cultivate their land as had been done for generations.

\section{Conceptual Framework}

The generic effect of inheriting land is an outward shift of the budget constraint affording an individual a more desirable consumption bundle: a 'wealth effect'. Additionally, in the context of credit constraints individuals may be able to leverage land as collateral and take advantage of high-return opportunities in the non-agricultural sector. However, if land markets are severely constrained by frictions, inheriting land also involves an opportunity cost. An inability to part with land through sales or rental markets - or, at an extreme, vacate it - may limit an individual's spatial mobility or ability to diversify into other occupations within rural areas. Estimating the marginal effect of inherited land will ordinarily combine both these effects.

To clarify these competing effects and motivate the empirical strategy, consider a conceptual experiment with three groups: a 'land' group that is randomly assigned an acre of land, a 'cash' group that is randomly assigned the equivalent value in cash and a control group which receives nothing. Assume that the 'land' group is prohibited from selling, renting or leaving the land; it is assumed to not be in their interest to leave it fallow. ${ }^{14}$ However, there

\footnotetext{
${ }^{14}$ It is worth noting here that many asset transfer programs prohibit the resale of assets to ensure that beneficiaries are provided with a basis for a livelihood rather than a temporary wealth shock (Das et al., 2013).
} 
exists a market where the 'cash' group may purchase land. We could then estimate the effect of our treatments on household consumption:

$$
\begin{aligned}
\beta_{w} & =\mathbb{E}(\text { Consumption } \mid \text { Cash }=1)-\mathbb{E}(\text { Consumption } \mid \text { Control }=1) \\
\beta_{w-c} & =\mathbb{E}(\text { Consumption } \mid \text { Land }=1)-\mathbb{E}(\text { Consumption } \mid \text { Control }=1) \\
\beta_{c} & =\mathbb{E}(\text { Consumption } \mid \text { Land }=1)-\mathbb{E}(\text { Consumption } \mid \text { Cash }=1)
\end{aligned}
$$

$\beta_{w}$ is the marginal effect of the cash endowment on household consumption and $\beta_{w-c}$ is the marginal effect of an acre of land on household consumption. By assumption $\beta_{w} \geq \beta_{w-c}$ as the latter effect involves an opportunity cost, $c$. This cost $c$ can be thought to derive from foregone returns in the non-agricultural sector imposed by the requirement that the 'land' group is unable to fully leverage this asset through markets.

Theoretically it is possible that $\beta_{w-c}$ could be positive, zero or even negative. For example, consider an individual in the 'land' group forced to make a living off an acre of land, while their counterfactual outcome in the control group would have been to get a job at a call center in the city. If the opportunity cost of remaining in agriculture were larger than the wealth effect we would get the perverse result that our control group has higher average household consumption than the 'land' group. ${ }^{15}$ Finally, assuming an additive marginal effect structure, we could estimate the size of this cost $c$ by comparing the outcomes of the 'land' group to the 'cash' group, i.e. $\beta_{c}$ in equation (3).

In practice, implementing the experiment described above may not be feasible both on account of its cost and, more importantly, because the institutional constraints required to capture these effects cannot reasonably be imposed on experimental subjects. In contrast, using plausibly exogenous variation in inherited landholdings I am able to recover estimates of these marginal effects by exploiting heterogeneity in factor market frictions. ${ }^{16}$ However, in contrast to the conceptual experiment, there is no 'cash' group and I estimate the effect

\footnotetext{
${ }^{15}$ Alternatively, in a constrained optimization framework we can motivate this idea by assuming that selling land involves a non-pecuniary cost $\alpha$ such that $\alpha>\beta_{c}$. This implies that the 'land' group may be just as well off in a welfare sense but there are observable implications in terms of occupational choice and consumption.

${ }^{16}$ The fact that land is inherited may also make the non-pecuniary costs of parting with this land more salient as a consequence of having farmed it for generations.
} 
on the intensive margin for land.

To make the first point of departure clear, the empirical strategy detailed in section 5 produces the equivalent of the 'land' group and the 'control' group. However, in this case the 'land' group is not prohibited from selling, renting or leaving the land. Instead, those who own land face different values of $\theta \in[0,1]$ a parameter that captures frictions in factor markets. Where $\theta$ is higher, it is more difficult to sell, rent or leave inherited land. In the empirical strategy detailed below $\theta$ is approximated by cultural obligations and transaction costs in the market for land.

Considering the extremes, an individual inheriting land that faces $\theta=0$ can be compared to someone assigned to the 'cash' group in the conceptual experiment : they can just sell the land and get the equivalent cash value. However, for those who own land and face $\theta=1$ it would be as though they were assigned to the 'land' group from the conceptual experiment. In this case, it is clear that causal estimates will recover a weighted average of $\hat{\beta}_{w}$ and $\hat{\beta}_{w-c}$ in estimating the marginal effect of household consumption and its analogous effect on occupational choice. In addition, we can use the heterogeneity in $\theta$ to estimate $\hat{\beta}_{c}$, the opportunity cost of inheriting land:

$$
\begin{aligned}
\hat{\beta}_{c}= & {[\mathbb{E}(\text { Consumption } \mid \text { Land }=1, \theta=1)-\mathbb{E}(\text { Consumption } \mid \text { Control }=1, \theta=1)] } \\
& -[\mathbb{E}(\text { Consumption } \mid \text { Land }=1, \theta=0)-\mathbb{E}(\text { Consumption } \mid \text { Control }=1, \theta=0)[4)
\end{aligned}
$$

Second, I estimate the difference in consumption for individuals with varying sizes of landholdings, i.e. the intensive margin. To map this to the conceptual experiment, imagine an individual who gets two acres of land relative to someone who gets an acre. While the pure wealth effect of 2 acres of land is larger than 1 acre (i.e. $\beta_{w, 2 a c r e s}>\beta_{w, 1 a c r e}$ ) the change in the opportunity cost is indeterminate (i.e. $\beta_{c, 2 \text { acre }} \geq \beta_{c, 1 \text { acre }}$ ). An increase in wealth may afford an individual alternatives that were not available to someone with less wealth (e.g. the cost of transportation to a more remunerative market). Another way of conceiving this is that $\theta$ itself may depend on the size of landholdings and, as such, the level of consumption with 2 acres of land could be larger, equal to or smaller than with 1 acre of land. ${ }^{17}$ While

\footnotetext{
${ }^{17}$ Larger landholdings may absorb more of an individuals time endowment resulting in less opportunity to diversify labor supply within rural areas: this implies that $\theta$ is increasing in the extent of landholdings.
} 
the empirical strategy estimates local average treatment effects, non-parametric estimations of the reduced form can reveal non-linearities in the estimated effects.

\section{Data}

The data used in this paper primarily draw from the 1999 wave of the ARIS/REDS ${ }^{18}$ data set (hereafter, 'REDS') collected by the National Council for Applied Economic Research (NCAER). ${ }^{19}$ The REDS data is a national probability survey intended to be representative of the rural population of India residing in 17 major states and 100 districts. It's distinctive features include a complete enumeration of respondent's siblings and children - not limited to those present at the household at the time of surveying - and data on a respondent's inherited landholdings and parent's landholdings. Additionally, the survey contains detailed data on consumption, non-farm and agricultural investments and labor supply.

The REDS panel was collected in four waves conducted between 1971 and 2006 and has previously been used in a number of prominent studies of the Green Revolution in India (Foster and Rosenzweig, 1995;Foster and Rosenzweig, 1996). The first round of the survey randomly sampled 4527 households in 259 villages, stratifying by farm size and wealth. The survey was originally intended to evaluate the impact of an agricultural development program, but was expanded beyond program districts in 1982 with the intention of making it nationally representative. All of the original villages were surveyed in the 1999 wave, excluding 8 sample villages from Jammu and Kashmir (owing to problems of local insurgency). Because of household divisions and the inclusion of a new random sample of households in each village, the number of households in the 1999 round increased to $7474 .^{20}$

The main sample used in the analysis presented below uses data from the 1999 wave and drops household heads whose parents owned no land (1,654 households) as by definition any landholdings they possess are not governed by the inheritance laws described above. While household heads from landless families are dropped from the main analysis, they are used

\footnotetext{
${ }^{18}$ Additional Rural Incomes Survey/Rural Economic and Demographic Survey

${ }^{19}$ This data is made available online by Prof. Andrew Foster from: http://adfdell.pstc.brown.edu/arisreds data/

${ }^{20}$ After merging in data across parts of the survey that includes separately elicited information on all siblings and children, the total number of households in the dataset drops to 7393 .
} 
in placebo tests to evaluate the validity of the exclusion restriction. Among the remaining 5,793 households, 338 female headed households are dropped because the data does not indicate whether the sibling data refers to the female head or her spouse, and a further 592 households of minorities are dropped as the study is restricted to Hindu households. ${ }^{21}$

The primary unit of analysis in this paper is the household head. However, data on all siblings and children of the household head are collected for a limited set of outcomes including education, migration, inherited and current landholdings. The very low level of permanent migration to urban areas in the period preceding the survey and the fact that most respondents were born prior to the introduction of affordable sex selection technologies make the 1999 wave particularly well suited to this analysis. ${ }^{22}$ In addition, this wave was the first to include detailed information on household structure, inheritances and agricultural labor.

In addition to the REDS data, this paper also makes use of the Indian Human Development Survey (IHDS) which was conducted in 2004-2005. The IHDS is a nationally representative, multi-topic survey of 41,554 households in 1503 villages and 971 urban neighborhoods across India. This survey is primarily used in analysis supporting the exclusion restriction owing to the larger sample size and urban sample. However, the IHDS does not collect information on land inheritances or family data on heads aside from the total number of siblings making it ill suited to the main analysis.

Finally, I collected data on household perceptions, understanding and the administration of inheritance rules from a sample of 1,200 households in rural Gujarat. These households were randomly selected from village lists of cotton farmers as a part of a separate study on technology adoption in agriculture (Cole and Fernando, 2014). This data was collected through paper based surveys in coordination with the Centre for Micro Finance in August, 2013.

\footnotetext{
${ }^{21}$ Note, the incorporation of households splitting over time after the 1982 round suggests that successive rounds cannot be considered nationally representative.

${ }^{22}$ In spite of low levels of permanent migration to urban areas, a potential selection concern arises from unobserved family migration to urban areas. While I observe whether all siblings and children of household heads migrate, I would not observe a household if entire families migrated to urban areas which may influence the estimates that follow. While this form of migration is considered very rare in rural India (Munshi and Rosenzweig, 2007), I perform a series of simulations that assess the robustness of the reduced form results to selective migration in Section 8.1, which are described in further detail in Appendix C2.
} 


\section{Empirical Strategy}

In the empirical analysis, I estimate the causal effect of inherited landholdings $L_{i j}$ on household consumption and labor mobility, $Y_{i j}$. In the case of the latter outcome, let $Y_{i j}$ be a dummy for holding a non-agricultural occupation. The structural equation of interest is:

$$
Y_{i j}=\alpha_{j}+\rho L_{i j}+X_{i j}+\nu_{i j}
$$

Where $\alpha_{j}$ is a district fixed effect and $X_{i j}$ is a set of controls which include characteristics of $i$ and his family background that might influence occupational choice. ${ }^{23}$ The concern here is that $L_{i j}$ is correlated with $\nu_{i j}$. For example, people who own more land may also have higher ability, $A_{i j}$, and this may in turn be positively correlated with exiting agriculture. When $A_{i j}$ omitted, OLS will biased upwards relative to $\rho$. In order to address this concern, I make use of an inheritance rule that results in land being divided equally between sons after a father's death to instrument for $L_{i j}$.

If the number of brothers an individual has is the product of a random process and the rule is binding, then, conditional on the number of siblings he has, it must also be the case that his inheritance share is the product of a random process. ${ }^{24}$ The functional form for this share is non-linear and equal to: Predicted Share $=\left[\frac{1}{1+\text { Brothers }}\right]$. Panel A and B in Figure 1 demonstrate the validity of this functional form assumption by showing how the empirical shares of inherited land vary with sibling sex composition. ${ }^{25}$ Panel A plots inheritance shares observed in the data by a household head's number of brothers (black dots). The empirical shares closely track what is predicted by the inheritance rule (red-dashed line). In contrast, Panel B shows that no such relationship exists in the analogous visualization by number of

\footnotetext{
${ }^{23}$ If we instead change the outcome variable to consumption, $\rho$ is a combination of $\beta_{w}$ in equation (1) and $\beta_{w-c}$ in equation (2) as the estimate is averaged over values of $\theta$, the measure of frictions in the conceptual framework.

${ }^{24}$ Sibling sex composition has previously been used in studies examining the effect of child bearing on labor supply and the 'quantity-quality' fertility trade-off (Angrist and Evans (1998); Angrist et al. (2010)).

${ }^{25}$ Appendix Table A2.2 and A2.3 provide additional support for equal division. Virtually all (93\%) households among the 1,037 surveyed in Gujarat report that parents do not deviate from the equal shares rule because of mitigating circumstances such as higher human capital or employment. Furthermore, a large majority $(71 \%)$ reported that brothers inherit the same quality of land. Column (1) in Appendix B2 shows, using within family estimates, that birth order does not predict the probability of inheriting land.
} 
sisters. $^{26}$

To illustrate the use of this instrument, consider the case of a respondent with one sibling. If that sibling is a brother then the individual inherits half the family land and the value of the instrument, Predicted Share, equals 0.5 . If, on the other hand, the respondent has as sister, the instrument equals 1 and he inherits all the family land. The identifying assumptions are that conditioning on the respondent's total number of siblings and his parent's landholdings, his predicted inheritance share is independent of potential outcomes and only affects these outcomes through the inheritance of land. The validity of these assumptions - the conditional independence assumption and the exclusion restriction assumption - are addressed in Section 8.

The 2SLS estimate computes a weighted average of the Wald estimator across individuals with varying numbers of siblings and family landholdings, weighted by the strength of the covariate specific first stage. Conceptualizing this in the LATE framework (Angrist and Imbens, 1995), the 2SLS estimate gives us the local average treatment effect for the compliers: the individuals who would have stood to inherit a larger share of their parent's land had one or more of their brothers been sisters. As such, the first stage (6) and second stage equations (7) are:

$$
\begin{gathered}
L_{i j}=\alpha_{j}+\pi \text { Pred } \text { Share }_{i j}+\gamma_{k} \sum_{k=1}^{K} I\left(\text { sibs }_{i j}=k\right)+\gamma_{l} \sum_{l=1}^{L} I\left(\text { fam land }_{i j}=l\right)+\epsilon_{i j} \\
Y_{i j}=\alpha_{j}+\rho \hat{L}_{i j}+\gamma_{k} \sum_{k=1}^{K} I\left(\text { sibs }_{i j}=k\right)+\gamma_{l} \sum_{l=1}^{L} I\left(\text { fam land }_{i j}=l\right)+\eta_{i j}
\end{gathered}
$$

Where $\alpha_{j}$ is a district fixed effect, Pred Share $_{i j}$ is the instrument as described above,

\footnotetext{
26 'Predicted share' is the preferred specification for the instrument as the functional form has a clear parallel to the visual in Panel A of Figure 1. Relative to instrumenting with the predicted level of land, the share has the advantage of being uncorrelated with controls for family land, being far less sensitive to outliers and having a larger first stage F-statistic as discussed in the following section. While using the natural logarithm of the level of land attenuates some of these concerns, estimates giving the marginal effect of an acre of inherited land are preferred to elasticities. In addition, use of the 'predicted share' instrument permits the comparison of marginal effects in placebo tests estimating the independent effects of sibling sex composition in the absence of it influencing inherited land (e.g. respondents from landless families and those residing in urban areas).
} 
$\sum_{k=1}^{K} I\left(\operatorname{sibs}_{i j}=k\right)$ is a set of dummy variables for the number of siblings $k$ in $i^{\prime} s$ family, $\sum_{l=1}^{L} I\left(\right.$ fam $\left._{\text {land }} \operatorname{laj}=l\right)$ is a set of dummy variables for parent's landholdings, $Y_{i j}$ is the outcome variable of interest, and $\hat{L}_{i j}$ are the first stage fitted values.

The causal effect of inherited land may also vary with underlying heterogeneity. For example, consider the case of whether a specific factor market friction is more or less binding (i.e. variation in $\theta$ from the conceptual framework). To test these hypotheses, I incorporate interaction effects into the structural equation. In this case for individual $i$, in village $j$ in district $k$ the structural equation is:

$$
Y_{i j k}=\alpha_{k}+\rho_{1} L_{i j k}+\rho_{2} Q_{j k}+\rho_{3}\left(L_{i j k} * Q_{j k}\right)+\gamma X_{i j k}+\nu_{i j k}
$$

Where $Y_{i j k}, L_{i j k}$ and $X_{i j k}$ are as above, $\alpha_{k}$ is a district fixed effect and $Q_{j k}$ is a dummy variable set to 1 if a factor market friction exists at the village level and 0 if not. $\rho_{1}$ is the causal effect of inherited land on holding a non-agricultural occupation, and $\rho_{3}$ tests whether the estimated effect varies across villages in which the factor market friction is present and those where it is not.

As $Q_{j k}$ is an approximation to $\theta$ discussed in the conceptual framework, if we consider $Y_{i j k}$ as household consumption instead, $\rho_{1}$ is now an estimate of $\beta_{w}$, the comparison between the 'cash' group and the 'control' group, while the sum of $\rho_{1}$ and $\rho_{3}$ is an estimate of $\beta_{w-c}$, the comparison between the 'land group' and the 'control' group. Finally, $\rho_{3}$ is an estimate of $\beta_{c}$; the opportunity cost of inheriting a marginal acre of land averaged over the intensive margin for land. Given two endogenous variables, I require at least two instruments: Pred Share ${ }_{i j k}$ and Pred Share $_{i j k} * Q_{j k}$. This results in two first stages to instrument for both $L_{i j k}$ and $L_{i j k} * Q_{j k}$ that share a common RHS as below:

$$
\begin{aligned}
\left(L_{i j k}, L_{i j k} * Q_{j k}\right)= & \alpha_{k}+\pi_{1} \text { Pred Share }_{i j k}+\pi_{2}\left(\text { Pred Share }_{i j k} * Q_{i j k}\right)+\pi_{3} Q_{j k} \\
& +\gamma_{z} \sum_{z=1}^{Z} I\left(\text { sibs }_{i j k}=z\right)+\gamma_{l} \sum_{l=1}^{L} I\left(\text { fam land }_{i j k}=l\right)+\epsilon_{i j k}
\end{aligned}
$$




\section{Results}

In the following sections I use the terms 'household head' and 'respondent' interchangeably. Additionally, I use the term 'predicted share' to refer to the instrument.

\subsection{Summary Statistics}

The first two columns of Table 1 report summary statistics for household head-level data, the primary unit of analysis. The remaining columns report summary statistics for sibling-level and child-level data, for which fewer outcomes are available. The mean age of a household head is 49 years, they have 5.8 years of education and spend roughly $\$ 80$ per month on household expenses. ${ }^{27}$ Nearly $30 \%$ of the population describe their primary activity status as being in a non-agricultural occupation. ${ }^{28}$ Of these respondents $32 \%$ hold a salaried job, $22 \%$ are engaged in non-agricultural wage labor and $18 \%$ report operating a non-farm business. ${ }^{29}$ Mean inherited landholdings are 4.12 acres while the median is 2 acres, suggesting a distribution of landholdings with a long right tail as in Panel A of Figure 2.

On average respondents became the head of their household at age 33 (median 32) or 16 years ago (median 14) - a proxy for their age of inheritance. In spite of this, Panel B shows that $70 \%$ of respondents have experienced no change in the current landholdings over their inherited landholdings and $84 \%$ of respondents have experienced increases or decreases of less than 2 acres over this period. For the median respondent, all current landholdings are inherited while the average share of inherited land in total landholdings is $83 \%$. Nearly $19 \%$ of the sample still have a living father. Among this subset $20 \%$ of respondents have inherited land, while for those with no living father $93 \%$ of respondents have inherited land ${ }^{30}$ The

\footnotetext{
${ }^{27}$ Appendix A1 provides details of the variables discussed in the analysis.

${ }^{28}$ Appendix C6 tests whether the main results are robust to alternative definitions of this variable. In particular, alternatively defining this variable as the occupation from which a respondent gets the majority of their income yields similar results.

${ }^{29}$ See Appendix A3 for details of salaried positions and non-farm businesses. The REDS data does not contain details on non-agricultural wage work, however for roughly 3000 respondents reporting non-agricultural wage labor in the IHDS, $36 \%$ are involved in construction work.

${ }^{30} 60 \%$ of respondents became the head of their household after their father died. While the survey does not give the exact time at which they inherited land, consistent with the summary statistics land is typically inherited upon a father's death. As is evident, however, household headship does not necessitate the inheritance of land or a father's death. Foster and Rosenzweig (2002) using the the REDS panel find that
} 
average household has 6 persons residing in it and nearly one-fifth of the sample has taken out a loan in the last five years. Respondents have 4 siblings on average, $52.3 \%$ of whom are male.

The means and standard deviations for sibling-level data are reported in columns (3) and (4). The average age of siblings is comparable to that of household heads, but a slightly lower fraction (67\%) inherit land. Rural to urban migration is very low at just 1.1\%. Column (5) shows that the children of household heads are aged 23 and have 5.4 years of education on average. A very small fraction (3\%) report inheriting land, as a consequence of their parents still being alive, and the rate of urban migration is comparable to that of the previous generation.

\subsection{First Stage and Reduced Form Estimates}

\subsubsection{First Stage}

As discussed in Section 5, Panel A of Figure 1 reveals that the data on empirical inheritance shares closely approximate what is predicted by the inheritance rule. ${ }^{31}$ A visualization of the first stage using the 'predicted share' instrument is presented in Figure 3. This figure plots the coefficients from a regression of inherited land on a set of dummies for each value of the instrument, with fixed effects for the number of siblings, districts and family landholdings. ${ }^{32}$ A clear pattern emerges where inherited landholdings rise on average as the predicted share increases. Column (2) in Table 2 confirms this graphical intuition and assesses five other parameterizations of the first stage. In each case, the instruments are highly correlated with inherited landholdings and yield first stage F-statistics ranging from 22 to $142 .{ }^{33}$

Column (1) reports the coefficient on the linear specification of the instrument which

household division (i.e. headship) is predicted by age of the respondent, household size and a co-resident wife but not by family landholdings.

${ }^{31}$ The empirical inheritance shares are calculated as self-reported inherited land divided by total land owned by parents, both of which are directly reported in the survey.

${ }^{32}$ The coefficients that are plotted the those on a set of dummies equal to 1 if the share is equal to 1 (no brothers), 0.5 (2 brothers) and so on. Individuals with more than 4 brothers are omitted for graphical clarity. They constitute less than $5 \%$ of the sample.

${ }^{33}$ As discussed in the following section, Appendix $\mathrm{C} 1$ shows that these alternative instrument specifications yield similar 2SLS estimates. 
yields a first stage F-statistic of $128 .^{34}$ Column (2) reports the coefficient on 'predicted share' $^{\prime}=\left[\frac{1}{1+\text { Brothers }}\right]$, and is precisely estimated with a F-statistic of 126. Column (3) in turn reports the coefficient on 'predicted land' $=\left[\frac{\text { Family Land }}{1+\text { Brothers }}\right]$, which has a weaker first stage $($ F-statistic $=101)$, likely due to the fact that family landholdings are themselves highly correlated with 'predicted land' leading to a lower partial F-statistic. ${ }^{35}$ Column (4) reports the coefficient on the natural logarithm of 'predicted land' which yields a F-statistic of 142. Finally, in column (5) the coefficients on a set of dummies for the number of brothers are reported, these instruments have a F-statistic of 22.

The coefficients reveal that the marginal effect of a brother on inherited landholdings is decreasing as the equal division rule would suggest. Substantively, an additional brother leads to a reduction in inherited landholdings of 1.24 acres on average or one-third of median landholdings in rural India. Therefore sibling sex composition induces substantial variation in inherited landholdings.

\subsubsection{Reduced Form}

Across four different instrument specifications, Panel A of Table 2 reports the reduced form coefficients for whether the head is primarily engaged in a non-agricultural occupation, while Panel B reports the reduced form coefficients for household consumption. ${ }^{36}$ Column (1) reports the coefficients on the linear specification of the instrument, column (2) reports the coefficient on 'predicted share', column (3) reports the coefficient on 'predicted land' and column (4) reports the coefficient on the natural logarithm of 'predicted land'.

Across instrument specifications, the coefficients reveal that having more male siblings (or as a consequence: a smaller predicted share or level of inheritance) has a positive effect on the probability of leaving agriculture and a negative effect on consumption. An exception to this uniformity is the reduced form coefficient for non-agricultural occupation using the

\footnotetext{
${ }^{34}$ All first stage specifications include district, sibling and family land fixed effects.

${ }^{35}$ Additionally, using an instrument specification that uses the level of inherited land will result in families with larger landholdings receiving disproportionate weight in the overall LATE as a marginal brother will induce more variation in the instrument for such families relative to those with smaller landholdings. In combination with a highly-nonlinear reduced form, this can yield estimates that do not reflect the the actual distribution of land that has a long right tail as in Panel A of Figure 2 but are rather driven by functional form assumptions.

${ }^{36}$ All reduced form specifications include district, sibling and family land fixed effects.
} 
'predicted land' instrument. While this is of concern, using the level of 'predicted land' is sensitive to outliers: both winsorizing $2.5 \%$ of the variable or using the natural logarithm of 'predicted land' as in column (4) yield highly significant reduced form estimates. In addition, the 'predicted land' instrument is highly correlated with the family land control, the omission of which also results in a significant reduced form effect.

Figure 4 plots the smoothed values and the $95 \%$ confidence bands from kernel-weighted local polynomial regressions of the reduced form for non-agricultural occupation (Panel A), rural-urban migration (Panel B) and household consumption (Panel C) using 'predicted land' instrument without family land controls. These figures show evidence of non-linearities in the estimated effects that are discussed in Section 7.3 in more detail.

\subsection{Occupational Choice, Migration and Consumption}

In the following sections I estimate (5) using two-stage least squares (2SLS), where the first stage specification is equation (6). Note, both the first and second stage equations include sibling, family landholdings and district fixed effects. ${ }^{37}$

\subsubsection{Occupational Choice}

In the presence of capital market imperfections, theories of occupational choice (Banerjee and Newman, 1993) predict that inherited land may act as collateral in accessing credit. It follows that the landed will be well positioned to take advantage of higher return investments in the non-agricultural sector, paving their way out of the subsistence or agricultural sector.

Table 3 reports the OLS (column 1) and 2SLS (column 2) estimates for the effect of inherited land on holding a non-agricultural occupation. ${ }^{38}$ The OLS estimate for the effect of land on the probability of transitioning out of agriculture is relatively small, at just 0.4\%. The 2SLS estimate, however, reveals a much larger effect having in part addressed omitted variable bias. The causal effect of inheriting an additional acre of land, contrary

\footnotetext{
${ }^{37}$ All specifications include district fixed effects (99 dummies), fixed effects for family landholdings (0-80+ acres, 5 acre intervals, 15 dummies) and the number of siblings (14 dummies).

38 'Non-Agricultural Occupation' is coded as 1 if the primary status reported by the respondent in the REDS survey is not self-cultivation or agricultural labor. Appendix C6 shows that these results are robust to using an alternative definition that directly computes primary occupation from reported sources of income.
} 
to the predictions of standard models of occupational choice, reduces the probability of transitioning out of agriculture by $-1.8 \%$ per acre on average. ${ }^{39}$ When restricting the sample to individuals whose families are in the first quartile of the family land distribution, this effect increases dramatically to $-21 \%$ per acre. The non-linearity in this effect suggested by this heterogeneity is apparent from non-parametric visualizations of the reduced form relationship.

Panels A in Figure 4 plots the smoothed values and the 95\% confidence bands from kernel-weighted local polynomial regressions of a dummy for holding a non-agricultural occupation on predicted land. ${ }^{40}$ The estimated slope is much steeper across 0-4 acres and levels off thereafter. This suggests that inherited landholdings are a particularly important determinant of occupational choice among those with smaller landholdings. They are also likely to be the individuals with the most to gain from higher returns to their labor in the non-agricultural sector, as their agriculture is characterized by subsistence rather than large profits. $^{41}$

\subsubsection{Migration to Urban Areas}

Inherited land may also facilitate movement of labor across space, to take advantage of higher returns to labor in urban areas (Bryan et al., 2011;Beegle et al., 2011). While the REDS data only surveys household heads in rural India, it records the movements of their siblings over space and records their inherited landholdings. ${ }^{42}$ This permits the estimation of (7)

\footnotetext{
${ }^{39}$ Appendix B5 shows that this effect is driven by those with more land being less likely to own a non-farm business. While the effects on entry in to salaried work and non-agricultural wage work are negative, they are imprecisely estimated.

${ }^{40} \mathrm{In}$ order to show the reduced form along a continuous support, PredictedLand $=\left[\frac{\text { Family Land }}{(1+\text { Brothers })}\right]$ is used instead of the main instrument Predicted Share. The family land control is dropped in this specification.

${ }^{41}$ This claim is supported by the stylized facts that emerge from the analysis in Appendix A4. Using data from the Indian Human Development Survey, this appendix reports estimates for occupational wage gaps in rural India and how they differ for farmers with varying sizes of landholdings. The analysis is similar to Gollin et al. (2014) in computing wage gaps between the agricultural and non-agricultural sectors, but differs in that it restricts this analysis to rural areas. The equivalent daily wage is higher in agriculture for those with landholdings above 3 acres relative to non-farm business and non-agricultural wage labor. However, for those with landholdings below 3 acres, daily wages in non-farm businesses (37\%), salaried work (74\%) and non-agricultural wage work $(9.2 \%)$ are higher on average. These estimates control for human capital, age, sex and district-level unobservables, but there could still be individual-level unobservables that drive these wedges.

${ }^{42}$ Note, these results are not from a household roster, which only gives details for co-resident siblings, but from a complete enumeration of all siblings irrespective of whether they are co-resident. Summary statistics
} 
using data on all siblings. As before, the variation is across households as within a family all male siblings stand to inherit the same amount of land.

Columns (3) and (4) in Table 3 report the OLS and 2SLS estimates for the effect of inherited land on rural to urban migration. The effect of inherited land on the rate of urban migration is negative and significant at $-0.02 \%$ per acre. For those whose families own less than 3 acres this effect is nearly 20 times as large at $-3.4 \%$ per are. Panel B in Figure 4 plots the smoothed values and the $95 \%$ confidence bands from kernel-weighted local polynomial regressions of rural-urban migration on predicted land. Once again, we see that while the estimate negative relationship is steep for amount of land up to 4 acres, beyond this point the estimates are imprecise and qualitatively unclear.

\subsubsection{Household Consumption}

While the prior estimates suggest that inherited land is an important determinant of leaving agriculture and migration, the implications of these findings for the level of consumption remain unclear. It may be the case that those with more land are more likely to remain in agriculture because it leaves them better off than leaving (i.e. the 'wealth effect', $\beta_{w}$ in equation (1) dominates the cost $\beta_{c}$ in (3) of inheriting land). Alternatively, inherited land may reduce spatial and occupational mobility to such an extent that they cause a lower level of consumption (i.e. $\beta_{w-c}<0$ ). The estimates that follow combine these effects as they average over frictions that exist in factor markets (i.e. $\theta$ from section 3 ).

Column (6) in Table 3 reports the causal effect of inherited land on the log of yearly household consumption. ${ }^{43}$ An additional acre of land increases household consumption in the long run by $2.7 \%$ on average. When restricting the analysis to respondents from families who own less than 3 acres of land, the point estimate is an imprecisely estimated $8 \%$. Panel $\mathrm{C}$ in Figure 4 shows the reduced form relationship graphically using local polynomial regressions. The estimated effect of predicted land on consumption is flatter from 0-2 acres and begins

for these 14,773 siblings are reported in columns (3) and (4) of Table 1.

${ }^{43}$ Household consumption is the preferred metric for empirical studies assessing poverty in India (Deaton and Dreze, 2002). Deaton (1997) suggests that income based measures may be more vulnerable to imputations, recall bias and seasonality. In addition, in this context the measurement of profits is made even more complicated by the valuation of household labor in both farm and non-farm businesses. 
to increase at a higher rate thereafter. ${ }^{44}$

\section{Mechanisms}

The results in the preceding section suggest that the inheritance of land limits spatial mobility and the likelihood of leaving agriculture but on average increases their level of consumption. This section looks at how these effects vary with underlying frictions (i.e. $\theta$ in the conceptual framework) in factor markets. In so doing, the regressions provide estimates of $\beta_{c}$ in equation (4) and suggest mechanisms through which these effects operate.

\subsection{Mechanisms: Access to Credit}

Initial endowments of land may facilitate a transition out of agriculture through increasing the ability of the landed to borrow and invest in high-return opportunities in the nonagricultural sector. However, if land does not effectively serve as collateral or financial institutions are absent this may not be the case. Column (1) in Table 4 shows that the OLS estimate for the effect of land on the probability of having taken out a loan in the last 5 years is $0.2 \%$. Column (2) shows that the 2SLS estimate increases to $1.5 \%$ and in each case the estimated coefficients are precisely estimated at the $1 \%$ level. The downward bias in the OLS estimate suggests that those who posses land may also have superior access to credit through other channels. Additionally, an additional acre of land increases the value of loans taken out on average by $15.2 \%$ (measured in log rupees). ${ }^{45}$ These results suggest that inherited land increases the ability of the landed to borrow and its effects on occupational choice, migration and household consumption obtain in spite of this.

\footnotetext{
${ }^{44}$ It is also possible that the effects may operate through the expectation of inheriting land in addition to the actual inheritance of land. Four-fifths of respondents with a living father are yet to inherit land. While controlling for this does not influence the 2SLS estimates, the estimation of effects on this sub-sample imperfectly captures the effect of expectations of inherited land. Appendix B1 estimates the effects on leaving agriculture (column 1), household consumption (column 2) and years of education (column 3) for individuals whose father is still alive. The evidence suggests that expectations do play a role in influencing occupational choice but not human capital acquisition or household consumption.

${ }^{45}$ While occupations may themselves influence the need to borrow, the number of loans does not vary appreciable between those primarily engaged in agriculture and non-agricultural work. Appendix A6.1 shows that a roughly equal amount of loans were taken out for agricultural and non-agricultural investment purposes. Additionally, Appendix A6.2 and A6.3 show that roughly 1/5 loans required collateral and in $83 \%$ of these loans land was used as collateral.
} 


\subsection{Mechanisms: Cultural Obligations and Labor Market Oppor- tunities}

A number of frictions may prevent individuals from renting, selling or leaving behind inherited land, effectively tying inheritors to their land (See Section 2.2). In the preceding 20 years, just $17 \%$ of the respondents report buying, selling or mortgaging their land. In addition, leaving land vacant may leave it vulnerable to expropriation, particularly given that just $40 \%$ of households in these villages own formal titles to their land. ${ }^{46}$

In this context of limited land markets and formal property rights, I consider a cultural obligation among Hindu families that may make it even more difficult to vacate inherited land. For the eldest son, taking care of his parents in their old age is a 'sacred duty' in Hindu scripture known as Pithru Rina (Kumari Bhat and Dhruvarajan, 2001). Upon the retirement of the father, the eldest son is obligated to take over the affairs of the household. In agricultural households this often implies responsibility for the family land and occupational succession, although the land is split equally thereafter regardless of birth order. ${ }^{47}$ Jayachandran and Pande (2013) find that parents invest more heavily in the first-born son in India; they are nearly 0.2 standard deviations taller for their age and have almost 2 years more schooling on average relative to second-borns, with the differences growing even larger with parity. ${ }^{48}$

Absent an obligation, this increased human capital endowment should leave household heads that are first-born sons considerably better off. However, by virtue of this obligation first-born sons ( $37 \%$ of the sample) may be less able to vacate their land (i.e. $\theta$, the measure of frictions, approaches 1) resulting in any effects on leaving agriculture and household consumption operating more stringently in comparison to latter-born sons (i.e. $\theta$ approaches 0). ${ }^{49}$ Table 4 estimates equation (8) from the empirical section, interacting land with a

\footnotetext{
${ }^{46}$ Goldstein and Udry, 2008 show that the threat of expropriation risk may influence agricultural investments in land and how such concerns may also distort labor market supply as in (Field, 2007)

${ }^{47}$ As a consequence of this responsibility, the eldest son may be exposed to farming earlier and develop more 'farm-specific' human capital. I interpret any such differences as a consequence of this obligation. A similar hypothesis is put forward by Laband and Lentz (1998), who argue that 'farm-specific' human capital may be a reason for the much higher observed rate of occupational succession by sons of farmers in the US.

${ }^{48}$ In contrast, Jensen and Miller (2011) show that parents may also strategically limit the education of children expected to remain at home in order to prevent them from migrating to the city.

${ }^{49}$ First-born in this case refers to the first-born in the family, regardless of sex. If this definition were
} 
dummy for whether the respondent is the first-born sibling. As such, the interaction between predicted share and a dummy for first-born son becomes an additional instrument in the first stage as in equation (9) in order to recover separate causal estimates for first-born sons and latter-born sons.

Column (1) in Table 5 shows that the effect of land on transitioning out of agriculture is $-4.4 \%$ (significant at the 1\% level) for each acre for first-born respondents and virtually zero for latter-born siblings. Turning to the intensive margin, the amount of time spent by firstborn heads in agricultural labor on their own farms (column 2) is differentially increasing in the extent of inherited land. The same is true of investments in hired labor (column 3) and improvements in their land including terracing and bunding (column 4). Conversely, latter-borns expend their labor in non-farm enterprises and the amount is increasing in their inherited landholdings (column 5), although this estimate is not significant at traditional levels. ${ }^{50}$ Using sibling-level data, column (6) shows that the probability of a first-born sibling migrating to urban areas is also decreasing in their inherited landholdings, but this relationship does not exist for their latter-borns.

Finally, column (7) considers the differential effects on household consumption that this obligation imposes on inheritors. First-born respondents have higher consumption on average consistent with parents investing heavily in children obligated to support them. However, we see that inherited land has a positive effect on household consumption on average $(3.4 \%$ per acre), but for first-born respondents there is a differential negative effect on consumption $(-2.9 \%$ per acre $)$ that results in the net effect of land on consumption to be indistinguishable from zero. ${ }^{51}$ This differential effect is also an estimate of $\beta_{c}$, the opportunity cost of land.

sex-specific it would not be independent of the instrument, as those with fewer male siblings are more likely to be the first-born son. This implies that some eldest sons are classified as 'latter-borns' because they have older sisters. Columns (3)-(6) in Appendix C6 show that controlling for latter-born eldest sons leads to small changes in the coefficients but not their qualitative interpretation.

${ }^{50}$ An analysis of sibling-level data also suggests that latter-born siblings may be reallocating land within the family towards their first-borns siblings. Appendix B2 reports the coefficients on the birth order dummies using within-family regression. Latter-borns are less likely to experience an increase in their current landholdings over their inherited landholdings. In the main sample, $26 \%$ of household heads report that they experienced an increase in their landholdings over the prior two decades. Of these respondents, nearly $40 \%$ report receiving 'gifts' of land, a category distinct to inheriting, leasing or purchasing land.The majority of these contracts are oral rather than written, they do not involve a fee and have no specified term.

${ }^{51}$ It is important to note here that omitted variable bias is likely to run counter to this result, as research (Jayachandran and Pande, 2013) shows that parents invest more resources (nutrition, education) in firstborns. 
Taking these estimates literally suggests that for an inheritance of 3 acres, these frictions imply a loss of consumption of $8.7 \%$.

This estimate of $\beta_{c}$ also places a bound on how large the non-pecuniary gain from adhering to this obligation - e.g. in terms of status - would need to be in order for welfare effect of land to be the same as for latter-borns. Figure 5 plots kernel-weighted local polynomial regressions of household consumption on predicted land by birth order. These figures show a dip in consumption for first-borns for inheritances of one acre but no corresponding dip for latter-borns, suggesting that $\beta_{c}$ is particularly high for marginal inheritances and reduces thereafter, which is also supported by the non-linearity of the reduced form for household consumption.

\subsubsection{Timing of Headship}

Appendix B3 suggests that the timing of the headship (a proxy for the age of inheritance) also matters. First-borns who become heads at a younger age are even more likely to remain in agriculture (column 3) and land has a net-negative effect on their level of consumption. In contrast, for latter-borns the age of headship does not appear to matter for either occupational choice or consumption (column $5 \& 6$ ). These estimates suggest that for a subset of respondents $\beta_{w-c}<0$, delivering the perverse result that those with less land are better off in terms of consumption. This may be a consequence of inheriting land earlier in life being especially important in terms of influencing occupational trajectories and precluding profitable opportunities through, for example, migrating to urban areas.

\subsubsection{Persistence of Culture}

Changing attitudes to cultural obligations may result in the attenuation of effects estimated in the previous section. However, the enumeration of details of all children of respondents allows us to look at whether these effects persist over generations. ${ }^{52}$. Specifically, if culture persists over generations first-born children will have a similar obligation to take care of their parents.

\footnotetext{
${ }^{52}$ Note, these results are not from a household roster, which only give details for co-resident children, but from a complete enumeration of all children irrespective of whether they are co-resident. Summary statistics for these 16,310 children are reported in Column (3) of Appendix Table A1
} 
Using the same 16,130 child-level observations in the REDS survey, I estimate equations (5) and (8) to identify the causal effect of land inherited by the head on the outcomes of his children and how these effects vary by the birth order of the children. In this case, standard errors are clustered at the family level. In column (1) of Table 6 we see that the causal effect of parent's landholdings on the average education of their children is positive. However, in column (2) we see that while first-born children are more educated than their latter-born siblings on average, their relative advantage decreases in the size of their parent's inherited landholdings, although this effect is not significant at traditional levels (t-statistic $=1.38$ ).

A similar story emerges for migration in columns (3) and (4). Migration is on average facilitated by greater landholdings, but there is a differential effect for first-born children. These results suggest culture persists as a mechanism through which the inheritance of land restricts mobility: first-born children become shackled to the land, restricting their movement over space.

\subsection{Mechanisms: Transaction Costs in the Market for Land}

Frictions in land markets may result in inherited land having an even larger influence on leaving agriculture and household consumption relative to where these frictions are less salient. In Table 7, I estimate whether the long-term effects of inherited land vary with transaction costs in the market for land. The reported coefficients are 2SLS estimates (equation (8)), using predicted share and its interaction with a measure of transaction costs as instruments for inherited land and it's interaction with transaction costs.

To measure transactions costs, columns (1) and (2) use a z-score index that combines 7 village-level measures of costs in the market for land. This index includes fees for registering landholdings, the cost of a Record of Rights certificate (RoR) and the travel time taken to get to the registrar's office. ${ }^{53}$ Column (1) shows that higher transactions costs serve to exacerbate the effect of land on restricting occupational choice although this effect is imprecisely estimated. Column (2) shows that higher transactions costs reduce the beneficial effects of inherited land on household consumption. In columns (3) and (4) the measure of

\footnotetext{
${ }^{53}$ A Record of Rights (RoR) certificate shows proof of ownership and can be used to obtain access to credit.
} 
transaction costs are whether there are additional fees that need to be paid in order to register one's landholdings in the village. Out of 246 villages, $60 \%$ have additional registration fees which on average amount to Rs. 1,019.83 (\$20 in 1999). The presence of additional registration fees similarly serves to tie individuals that inherit land even more to agriculture and in so doing reduce the consumption benefits from inheriting land. ${ }^{54}$

\section{Robustness Tests}

\subsection{Selection Concerns from Urban Migration}

A potential selection concern arises from the fact that all surveyed household heads in the REDS dataset reside in rural areas. I observe the location of all siblings of household heads - irrespective of whether they reside in rural or urban areas - and their inherited landholdings which allows me to estimate the negative effect of inherited land on urban migration. However it may still be the case that entire families inherited large amounts of land that facilitated their migration to urban areas and I do not observe this in the data. Omitting these 'missing migrants' may result in an overestimate of the negative effect of land on migration or occupational choice. However, studies suggest that the wholesale rural-tourban migration of families is extremely rare in India (Munshi and Rosenzweig, 2007) and Foster and Rosenzweig (2007) estimate that just 3-5\% of all males aged 15-24 migrated in each of the three decades preceding the 1999 wave of the REDS survey.

Nevertheless, I simulate the effect of a 10\% rural-to-urban migration rate on the reduced form relationship for non-agricultural occupation. ${ }^{55}$ Across a series of covariate values - family landholdings and number of siblings - that are most favorable to overturning the reduced form effect, I find that the implied sex composition of such migrants required to overturn the reduced form is very different to what is empirically observed in the IHDS dataset which

\footnotetext{
${ }^{54}$ The nature of the crop-specific production function may also influence $\theta$ - the measure of frictions in factor markets. Appendix B3 shows that household heads inheriting land and cultivating paddy - a labor intensive crop - relative to wheat, are even less likely to transition out of agriculture. However, this analysis is complicated by endogenous crop choice and the fact that rice, on the whole, a more profitable crop.

${ }^{55}$ This is the census-based individual urban migration rate for the three decades preceding the REDS survey.
} 
surveys such migrants. ${ }^{56}$ In particular, even assuming that all 'missing migrant' families have landholdings in the 95th percentile, virtually all such migrants would also need to be the only son in their family for the confidence interval to not contain the actual reduced form estimate. In contrast, the IHDS data reveals that just $11 \%$ of such rural-to-urban migrants are only sons.

\subsection{Addressing Instrument Validity: Conditional Independence Assumption}

A number of studies (Sen, 1990; Gupta, 2005) document the fact that sex ratios, particularly in north-west India, are substantially skewed towards males reflecting a preference for sons. In this context, parents may influence the sex composition of their children through differential care for daughters or through sex-selective abortion. However, the majority of the REDS sample were born prior to the widespread availability of ultrasound technologies, which provided a low-cost way to facilitate sex selective abortion in rural India. ${ }^{57}$ Nevertheless, I carry out a series of robustness checks that control for proxies of the demand for sex-selection established in the literature. ${ }^{58} 59$ Alternatively, given a preference for sons, differential stopping behavior may result in families with otherwise similar resources having different numbers of children based on when they achieve their desired number of sons. While both of these cases are of a concern to the conditional independence of the instrument, the robustness tests that follow suggest that this assumption is not violated.

\footnotetext{
${ }^{56}$ Appendix $\mathrm{C} 2$ contains a detailed discussion of these simulations and the choice of covariate values.

${ }^{57}$ In the REDS data, $99.7 \%$ of household heads were born prior to 1980 when ultrasound technologies became widely available in India. While other methods such as amniocentesis may have preceded this, their availability in rural areas was more limited (Arnold et al., 2002)

${ }^{58}$ Specifically, I check whether the results are robust to the inclusion of controls for the demand for sex selection as in Vogl (2013). The estimates in column (2) of appendix C4 include 223 fixed effects for the exact permutation of the sex of older siblings. The estimated effects are largely similar to those in the main specification. The exception is the point estimate for consumption which is not precisely estimated, presumably on account of the reduction in covariate specific variation (the First stage F-statistic reduces by one-third).

${ }^{59}$ Differential investment or care may still pose a concern if the types of families who selectively provide less nutrition and other care for female children also have unobserved characteristics that influence the future success of their sons. In order to address this concern, I check in column (3) of appendix C4 whether the results are robust to a set of 18 dummies $(0-10+$ years, 6 month intervals) that control for the average spacing between siblings. The assumption here is that differential care would lead to an increase in the average spacing between births of siblings, but there is virtually no change in the estimated coefficients.
} 


\subsubsection{Sex Selective Preferences: 'Balance' Test}

A priori, it is unclear which household attributes are correlated with a preference for sons. One possibility is that households which prefer sons are also those willing to invest additional parenting effort in supporting them, implying that the coefficient on inherited land is biased upward. Alternatively, households which prefer more sons and are willing to influence the sex composition of their children may be less educated. Such parents may consequently also lack the human capital to guide their sons into more lucrative occupations and this would bias the estimate downwards.

The 'balance' tests in Table 8 provide further support for the conditional independence assumption for the instrument. Characteristics of the household head and his family are regressed on the instrument, predicted share, while controlling for the number of siblings and family landholdings as in specification (6). Columns (2)-(5) report the coefficient on the instrument by number of siblings a respondent has, while column (6) includes the entire sample. The estimates suggest that the instrument is independent of a number of respondent characteristics including age, education, birth order and average spacing between siblings for the respondents. In addition, the literature on sex selective abortion in India finds that a mother's education is an important (positive) correlate of sex-selective abortion (Pörtner, 2010). While, we observe such an imbalance for respondents with four siblings, this effect is reversed for those with three siblings. More generally, the pooled sample (column 6) reveals that there is no systematic relationship between sibling sex composition and mother's education across sibling cohort sizes. ${ }^{60}$

\footnotetext{
${ }^{60}$ Although there are imbalances for a few characteristics in specific sibling cohort sizes, they vary qualitatively across cohort sizes suggesting the absence of systematic bias across these characteristics, and are not significant in the pooled sample (column 6). The only imbalance that is significant for the pooled sample is the time at which the respondent became the head of the household, with those with a higher predicted share becoming heads at a slightly younger age. This result appears to be driven by individuals with four siblings, and is only marginally significant in the pooled sample. Appendix C3 reports the 2SLS estimates for the effect of inherited land on occupational choice and household consumption by sibling cohort size. The estimated effects do not vary qualitatively across sibling cohort sizes, once again reducing concerns about the imbalances in Table 8.
} 


\subsubsection{Differential Stopping Rules}

As suggested above, another threat to the conditional independence of the instrument stems from son-preferring, differential stopping behavior (SP-DSB). On average, women in India are more likely to belong to families with a larger number of siblings and have less education on average (Jensen, 2003). While the inclusion of sibling fixed effects takes care of some of these concerns, it may still be the case that families with different fertility constraints or preferences end up with a similar number of children, resulting in an apples to oranges comparison in the regressions of interest.

To address concerns from stopping rules, I use an instrument that only uses variation from siblings born prior to the respondent - those who are, by definition, unaffected by stopping rules - and estimate my results restricting the sample to a subset where a fertility constraint is more likely to have been satisfied. ${ }^{61}$ In both cases the estimates are largely consistent with those from the preferred specification. Appendix $\mathrm{C} 4$ discusses these tests in detail.

\subsection{Addressing Instrument Validity: Exclusion Restriction As- sumption}

A key concern with estimation strategies relying on instrumental variables is the validity of the exclusion restriction assumption. In this context, the independent effects of sibling sex composition on human capital and dowry payments are of particular concern. In the former case, either a desire for diversification through reducing income covariance or decreasing returns to investing in the education of successive male children may result in respondents from families with more brothers having less education on average. In the case of dowry payments, families must typically pay a substantial sum for the dowry of a daughter when she marries. This may result in families with a higher composition of female children being more credit constrained thereby potentially influencing the cash reserves their sons are able to draw upon.

\footnotetext{
${ }^{61}$ The restriction is the subset of respondents whose youngest sibling is female. By definition, such families could not have engaged in son-preferring differential stopping behavior
} 
Controlling for education and dowry payments does not change the 2SLS estimates. ${ }^{62}$ However, column (1) in Appendix C5 shows that the first stage for years of education is indeed negative implying that those with more land have more education, and that this bias runs counter to the finding that less land may be beneficial. In contrast, the parents of respondents with fewer sisters incur less dowry payments, suggesting that those who have less land may also have less credit constrained parents. ${ }^{63}$ The first stage for land is 10-15 times as large as the first stage for these alternative channels, suggesting that 2SLS coefficients are less sensitive to these exclusion restriction violations. ${ }^{64}$ Nevertheless, in the next subsections I discuss how a number of placebo tests that can be used to support the claim that the primary channel through which the instrument influences outcomes is through the inheritance of land.

\subsubsection{Placebo Test: Areas with Historically Matrilineal Inheritance Customs}

Table 9 tests whether the findings in this paper are present in regions of India with historically matrilineal inheritance customs. Such customs entitle women to inherit more land on average relative to other parts of India. As such, the first stage for inherited land in these areas may be much weaker, but any other effects of sibling sex composition that operate through alternative causal channels should still influence outcomes in these areas. However, it may also be the case that sibling sex composition influences education or dowry receipts differently

\footnotetext{
${ }^{62}$ In column (2) of Appendix C5 I add a set of 12 dummy variables (0-13, 1 year intervals) that control for the education of the respondent to the main specification (equation (6)). These controls mostly leave the estimates unchanged relative to the main specification. Similarly, in column (2), I add to the main specification a set of 19 dummy variables (Rs. -50,000 - Rs. 50,000, Rs. 5000 intervals) that control for net dowry receipts. Once again, the 2SLS estimates are left largely unchanged.

${ }^{63}$ Column (2) in Appendix C5 reports the first stage for a dummy coded as 1 if net dowry receipts are above the median (Rs. 0). Net dowry receipts are defined as the net sum of all dowry paid and received for all siblings of the respondent. The use of a median threshold rather than the natural logarithm - used for all other rupee values - is on account of many values being negative. However, while $37 \%$ of the respondents have 0 net dowry, the 5 th percentile is Rs. $-27,200$ and the 95 th percentile is Rs. 30,000 , although the mean is just Rs. 1,471, leading to OLS estimation in levels to be greatly influenced by outliers.

${ }^{64}$ Conley et al. (2012) show that in the just identified case, the bias in the 2SLS estimate resulting from a violation of the exclusion restriction is proportional to $\frac{\gamma}{\pi}$ where $\gamma$ is the size of the exclusion restriction violation and $\pi$ is the first stage coefficient for the endogenous variable of interest. Given that in this case $\pi$ is 125.95 in the preferred specification, Appendix C8 shows that $\gamma$ has to be extremely large in order for the confidence interval to cover zero using the 'union of confidence intervals' approach to checking the sensitivity of the estimates to violations of the exclusion restriction. The tests show that virtually all of the reduced form effect for non-agricultural occupation (Panel A) and household consumption (Panel B) has to operate through other channels, which is at odds with the ratio of the first stages for other candidate channels.
} 
across matrilineal and patrilineal areas reducing the credibility of the placebo test. To address this concern, column (1) tests whether the first stage for education varies across matrilineal and patrilineal states using the REDS data.

If anything, it appears that in matrilineal states having fewer brothers leads to even more education for the respondent on average, relative to patrilineal states. As expected, the first stage for inherited land in matrilineal states (column 3) is much weaker and the point estimate is significantly different from patrilineal states. The reduced form effects of predicted share on non-agricultural occupation (column 3) and household consumption (column 4) are significantly different in matrilineal states, supporting the assumption that the instrument primarily operates through the land inheritance channel.

\subsubsection{Placebo Test: Landed versus Landless Families}

Respondents whose parents owned no land provide another means to investigate the causal channel of the instrument. The REDS dataset contains 1,315 such individuals who are not a part of the main sample of 4,809 respondents. By definition, these individuals cannot inherit land from their parents, however any independent effects of sibling sex composition should still influence their outcomes. Once again, it may be the case that sibling sex composition and dowry operate differently for landless families. Columns (5) and (6) of Table 9 show that the point estimate on inherited land from the first stage regressions for education and dowry are not systematically different across individuals from landed and landless families.

In contrast, column (7) and column (8) show that the reduced form effects of the instrument on non-agricultural occupation and consumption, respectively, are significantly different. ${ }^{65}$ As in the case of the matrilineal placebo, the differential effects are large in magnitude, and precisely estimated. Once again, these estimates lend support to the claim that the effects of sibling sex composition on occupational choice and household consumption primarily operate through the inheritance of land. ${ }^{66}$

\footnotetext{
${ }^{65}$ It is worth noting here that household heads with more brothers - those with a lower predicted share are more likely to report that they set up a new household when they became the head of their family as opposed to assuming their parent's household. However, this does not differ across respondents from landed and landless families.

${ }^{66}$ Appendix C7 details two further placebo tests: First, the reduced form effect for non-agricultural occupation (column 2) and household consumption (column 3) are qualitatively different but imprecisely estimated for those inheriting after reforms to inheritance laws that allow sisters to inherit land. Second, the null
} 


\section{Conclusion and Discussion}

Using a novel instrumental variables strategy that relies on variation arising from sibling sex composition and Hindu inheritance customs, the primary contribution of this paper is to shed light on the importance of frictions and cultural obligations together with the inheritance of land in explaining the observed persistence of labor in the agricultural sector.

Contrary to theories of poverty traps emphasizing the importance of initial endowments, I find that inherited land does not facilitate the movement of labor out of the agricultural sector. Rather, for the majority of the population I find the opposite: inheriting land reduces the likelihood of exiting agriculture both within rural areas and through migration to urban areas. For those inheriting below median landholdings the effect sizes are more than ten times as large.

Further, I find that cultural obligations and land market transaction costs undermine the benefits of inherited land. In the presence of such frictions, inheriting land results in two competing forces. On the one hand larger landholdings result in a wealth effect, expanding the consumption of inheritors. On the other, they influence the long-term occupational trajectory of inheritors - with younger inheritors more affected - nudging them towards the agricultural sector. This latter effect results in foregone higher returns in the non-agricultural sector, which may be particularly large for smaller farmers. Depending on the balance of these effects, the net effect of inherited land on consumption can be zero or even negative.

The findings of this paper suggest that frictions in land markets and cultural obligations may be an important source of labor market misallocation in rural India. Individuals wishing to part with inherited land passed through a family for generations may face unique constraints. However, as entry into smallholder farming in the developing world continues to be dominated by systems of inheritance rather than markets, these concerns need not be limited to the present context. As a consequence, the most productive farmers may be unable to enter agriculture resulting in suboptimal agricultural productivity. Future work may test this implication by estimating how land market reforms and changes to inheritance

hypothesis (zero effect) cannot be rejected for the the reduced form effect for household consumption in urban areas (column 4). 
laws influence agricultural productivity and labor mobility. ${ }^{67} \mathrm{~A}$ second implication is that interventions that improve the returns to unproductive farmers remaining in agriculture will create additional distortions in labor markets. Spatial and temporal variation in large scale programs intended to improve agriculture would provide a test of this implication.

An important caveat to my findings is that consumption may not adequately capture welfare. Incorporating measures of productivity as discussed above and subjective measures of well-being will strengthen the evidence for misallocation. Finally, given the preponderance of patrilineal inheritance laws across the developing world, a similar instrumental variables strategy can be used to understand the importance of inherited assets for labor market outcomes across a number of contexts. ${ }^{68}$

\footnotetext{
${ }^{67}$ For example, in India the computerization of land registries and amendments to the Hindu Succession Act may have important consequences for labor market outcomes through influencing the channels discussed in this paper.

${ }^{68}$ For example, Kuran, 2012 studies the implications of Islamic inheritance laws, where male heirs typically inherit twice the amount that daughters inherit.
} 


\section{References}

Agarwal, B. (1994). A field of one's own: Gender and land rights in South Asia, vol. 58. Cambridge University Press.

Angrist, J. and Evans, W. (1998). Children and their parents labor supply: Evidence from exogenous variation in family size. The American Economic Review, 88 (3), 450-477.

—, LAVy, V. and Schlosser, A. (2010). Multiple experiments for the causal link between the quantity and quality of children. Journal of Labor Economics, 28 (4), 773-824.

Angrist, J. D. and Imbens, G. W. (1995). Two-stage least squares estimation of average causal effects in models with variable treatment intensity. Journal of the American statistical Association, 90 (430), 431-442.

Arnold, F., Kishor, S. and Roy, T. (2002). Sex-selective abortions in india. Population and Development Review, 28 (4), 759-785.

Auty, R. (1993). Sustaining development in mineral economies: the resource curse thesis.

Bandiera, O., Burgess, R., Gulesci, S., Rasul, I. and Sulaiman, M. (2011). Can entrepreneurship programs transform the economic lives of the poor?

Banerjee, A. V. and Newman, A. F. (1993). Occupational choice and the process of development. Journal of political economy, pp. 274-298.

Beegle, K., De Weerdt, J. and Dercon, S. (2011). Migration and economic mobility in tanzania: Evidence from a tracking survey. Review of Economics and Statistics, 93 (3), $1010-1033$.

Besley, T. and Burgess, R. (2000). Land reform, poverty reduction, and growth: evidence from india. Quarterly Journal of Economics, pp. 389-430.

Bianchi, M. and BobBA, M. (2012). Liquidity, risk, and occupational choices. The Review of Economic Studies, p. rds031. 
Blattman, C., Fiala, N. and Martinez, S. (2013). Credit constraints, occupational choice, and the process of development: long run evidence from cash transfers in uganda. SSRN Scholarly Paper.

Bleakley, H. and Ferrie, J. (2010). Shocking behavior: Land lotteries in 1832 georgia and 1901 oklahoma and later life outcomes.

- and Ferrie, J. P. (2013). Up from Poverty? The 1832 Cherokee Land Lottery and the Long-run Distribution of Wealth. Tech. rep., National Bureau of Economic Research.

Bryan, G., Chowdhury, S. and Mobarak, A. M. (2011). Seasonal migration and risk aversion.

Chernina, E., Castañeda Dower, P. and Markevich, A. (2013). Property rights, land liquidity, and internal migration. Journal of Development Economics.

Cole, S. A. and Fernando, A. N. (2014). The value of advice: Evidence from mobile phone-based agricultural extension.

Conley, T. G., Hansen, C. B. and Rossi, P. E. (2012). Plausibly exogenous. Review of Economics and Statistics, 94 (1), 260-272.

Das, N., Yasmin, R., Ara, J., Kamruzzaman, M., Davis, P., Behrman, J., Roy, S. and Quisumbing, A. R. (2013). How do intrahousehold dynamics change when assets are transferred to women? evidence from bracs challenging the frontiers of poverty reductiontargeting the ultra poor program in bangladesh.

De Janvry, A., Emerick, K., Gonzalez-Navarro, M. and Sadoulet, E. (2012). Certified to migrate: Property rights and migration in rural mexico.

DeAton, A. (1997). The analysis of household surveys: a microeconometric approach to development policy. World Bank Publications.

— and Dreze, J. (2002). Poverty and inequality in india: a re-examination. Economic and Political Weekly, pp. 3729-3748. 
Deininger, K. and Feder, G. (2001). Land institutions and land markets. Handbook of agricultural economics, 1, 288-331.

- and Goyal, A. (2012). Going digital: Credit effects of land registry computerization in india. Journal of Development Economics, 99 (2), 236-243.

—, - and Nagarajan, H. (2013). Women's inheritance rights and intergenerational transmission of resources in india. Journal of Human Resources, 48 (1), 114-141.

-, Jin, S. and Nagarajan, H. K. (2008). Efficiency and equity impacts of rural land rental restrictions: Evidence from india. European Economic Review, 52 (5), 892-918.

—, - and — (2009). Determinants and consequences of land sales market participation: Panel evidence from india. World Development, 37 (2), 410-421.

FielD, E. (2007). Entitled to work: Urban property rights and labor supply in peru. The Quarterly Journal of Economics, pp. 1561-1602.

Fors, H. C., Houngbedji, K. and Lindskog, A. (2015). Land certification and schooling in rural ethiopia.

Foster, A. D. and Rosenzweig, M. R. (1995). Learning by doing and learning from others: Human capital and technical change in agriculture. Journal of political Economy, pp. 1176-1209.

— and — (1996). Technical change and human-capital returns and investments: evidence from the green revolution. The American economic review, pp. 931-953.

— and - (2002). Household division and rural economic growth. Review of Economic Studies, pp. 839-869.

— and - (2007). Economic development and the decline of agricultural employment. Handbook of development economics, 4, 3051-3083.

Galor, O. and ZeIra, J. (1993). Income distribution and macroeconomics. The review of economic studies, 60 (1), 35-52. 
Goldstein, M. and Udry, C. (2008). The profits of power: Land rights and agricultural investment in ghana. Journal of Political Economy, 116 (6), 981-1022.

Gollin, D. (2014). The lewis model: A 60-year retrospective. Journal of Economic Perspectives, 28 (3), 71-88.

—, Lagakos, D. and Waugh, M. E. (2014). The agricultural productivity gap. Quarterly Journal of Economics.

- and Rogerson, R. (2010). Agriculture, roads, and economic development in uganda. NBER Working Paper.

GulESCI, S. (2012). Labor-tying and poverty in a rural economy: evidence from bangladesh. Tech. rep., IGIER (Innocenzo Gasparini Institute for Economic Research), Bocconi University.

Gupta, M. D. (2005). Explaining asia's missing women: a new look at the data. Population and development review, 31 (3), 529-535.

Harris, J. R. and Todaro, M. P. (1970). Migration, unemployment and development: a two-sector analysis. The American Economic Review, pp. 126-142.

Jayachandran, S. and PAnde, R. (2013). Why are indian children shorter than african children? Department of Economics, Northwestern University, Mimeo.

Jensen, R. and Miller, N. (2011). Keepin' em down on the farm: Migration and strategic investment in childrens schooling. Unpublished manuscript.

Jensen, R. T. (2003). Equal Treatment, Unequal Outcomes?: Generating Sex Inequality Through Fertility Behaviour.

Jodhka, S. S. (2006). Beyond'crises': rethinking contemporary punjab agriculture. Economic and Political Weekly, pp. 1530-1537.

Kumari Bhat, A. and Dhruvarajan, R. (2001). Ageing in india: drifting intergenerational relations, challenges and options. Ageing and Society, 21 (05), 621-640. 
Kuran, T. (2012). The long divergence: How Islamic law held back the Middle East. Princeton University Press.

Laband, D. N. and Lentz, B. F. (1998). The effects of sexual harassment on job satisfaction, earnings, and turnover among female lawyers. Industrial and Labor Relations Review, pp. 594-607.

Lambert, S., Ravallion, M. and Van de Walle, D. (2014). Intergenerational mobility and interpersonal inequality in an african economy. Journal of Development Economics, 110, 327-344.

LEwIS, W. A. (1954). Economic development with unlimited supplies of labour. The manchester school, 22 (2), 139-191.

Morris, S. and PAndey, A. (2007). Towards reform of land acquisition framework in india. Economic and Political Weekly, pp. 2083-2090.

Munshi, K. and Rosenzweig, M. (2007). Why is mobility in india so low? social insurance, inequality, and growth.

Piketty, T. (2014). Capital in the Twenty-first Century. Harvard University Press.

Pörtner, C. C. (2010). Sex selective abortions, fertility and birth spacing. University of Washington, Department of Economics, Working Paper.

RAO, N. (2007). Custom and the courts: ensuring women's rights to land, jharkhand, india. Development and change, 38 (2), 299-319.

SEn, A. (1990). More than 100 million women are missing. The New York Review of Books.

Shahe Emran, M. and Shilpi, F. (2010). General equilibrium effects of land market restrictions on labor market: evidence from wages in sri lanka. World Bank Policy Research Working Paper Series, Vol.

Sharma, A. (2007). The changing agricultural demography of india evidence from a rural youth perception survey. International Journal of Rural Management, 3 (1), 27-41. 
Skoufias, E. (1995). Household resources, transaction costs, and adjustment through land tenancy. Land Economics, pp. 42-56.

VogL, T. S. (2013). Marriage institutions and sibling competition: Evidence from south asia*. The Quarterly journal of economics, 128 (3), 1017-1072.

WANG, S.-Y. (2012). Credit constraints, job mobility, and entrepreneurship: Evidence from a property reform in china. Review of Economics and Statistics, 94 (2), 532-551. 


\section{FIGURE 1: RULE-BASED AND EMPIRICAL INHERITANCE SHARES OF FAMILY LAND}
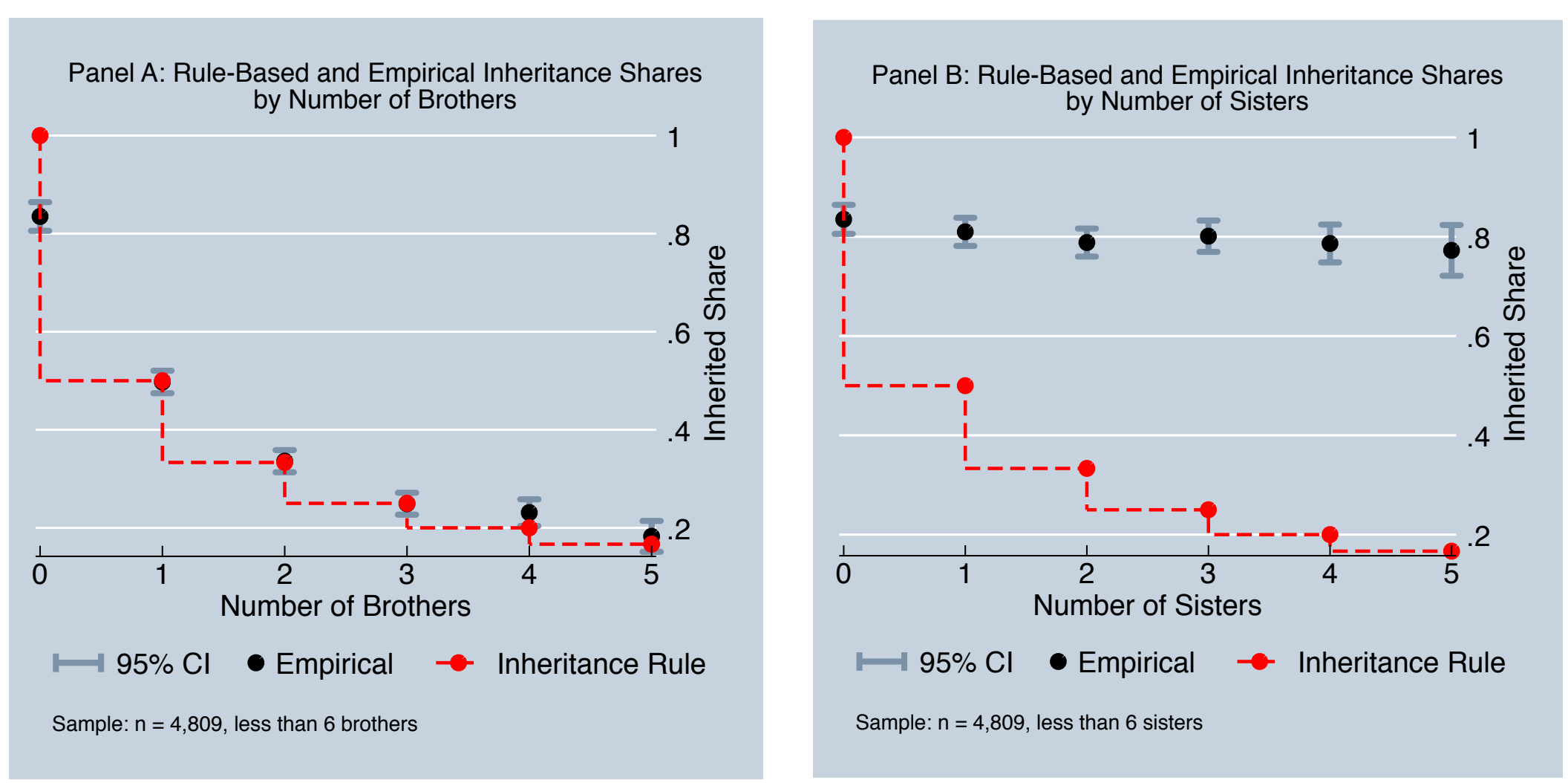

Notes:

These figures plot the inheritance shares predicted by the instrument and the empirical inheritance shares observed in the data. Panel A shows empirical inheritance shares by the number of brothers a respondent has, while Panel B shows it by the number of sisters. The 'Inheritance Rule' in each panel is the value of the instrument, i.e. 1/(1+Brothers). The Empirical share is calculated as the land inherited by the head divided by the land owned by his family. For Panel A this value is regressed on a set of dummies for the number of brothers (sisters for Panel B) and individual has, controlling for the number of sisters (brothers for Panel B). Household head's with 5 brothers or less (domain of Panel A) account for $98.49 \%$ of the sample. Household head's with 5 sisters or less (domain of Panel B) account for $98.05 \%$ of the sample. Data Source: ARIS-REDS Dataset 

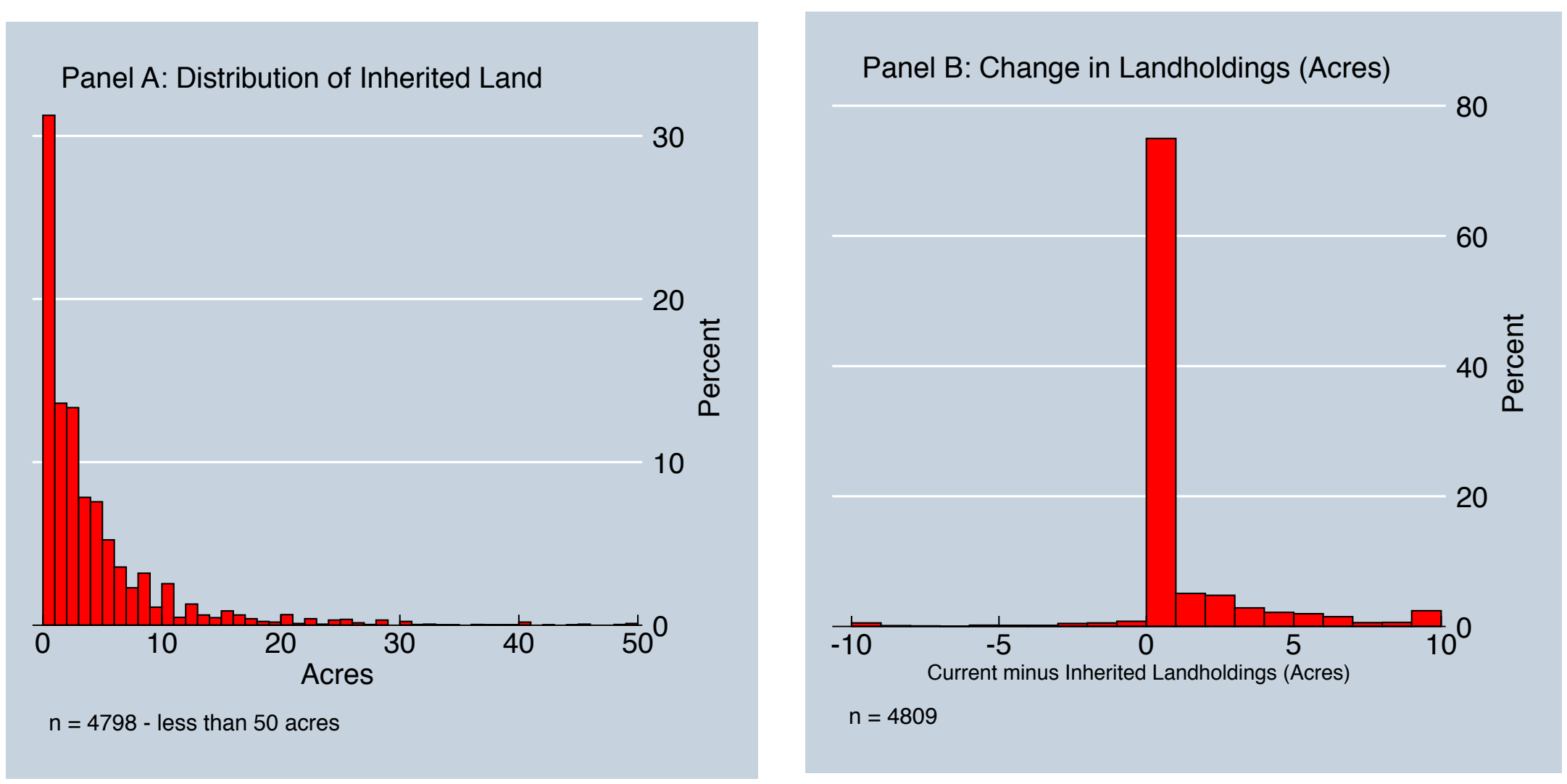

Notes:

Panel A plots the distribution of inherited landholdings. Panel B plots the difference between current and inherited landholdings. In the full sample $(n=4,809)$ $20.8 \%$ of households report that they inherited no land, $17.2 \%$ report inherited landholdings of $0-1$ acres, $15.2 \%$ report inherited landholdings between $1-2$ acres, $10.0 \%$ report between $2-3$ acres, $8.3 \%$ report between 3-4 acres, and the remainder ( $>4$ acres) account for $28.2 \%$ of the sample. The mean is 4.12 acres and the median is 2 acres. Panel A limits the domain to those who inherit less than or equal to 50 acres of land. Panel B codes increases of greater than 10 acres as 10 , and decreases of greater than 10 acres and $-10.70 \%$ of respondents report no change in inherited landholdings, while $84.4 \%$ report changes of less than 2 acres. The 95 th percentile is a change of +6 acres while the 5 th percentile is 0 . Data Source: ARIS-REDS Dataset. 


\section{FIGURE 3: VISUALIZATION OF FIRST STAGE}

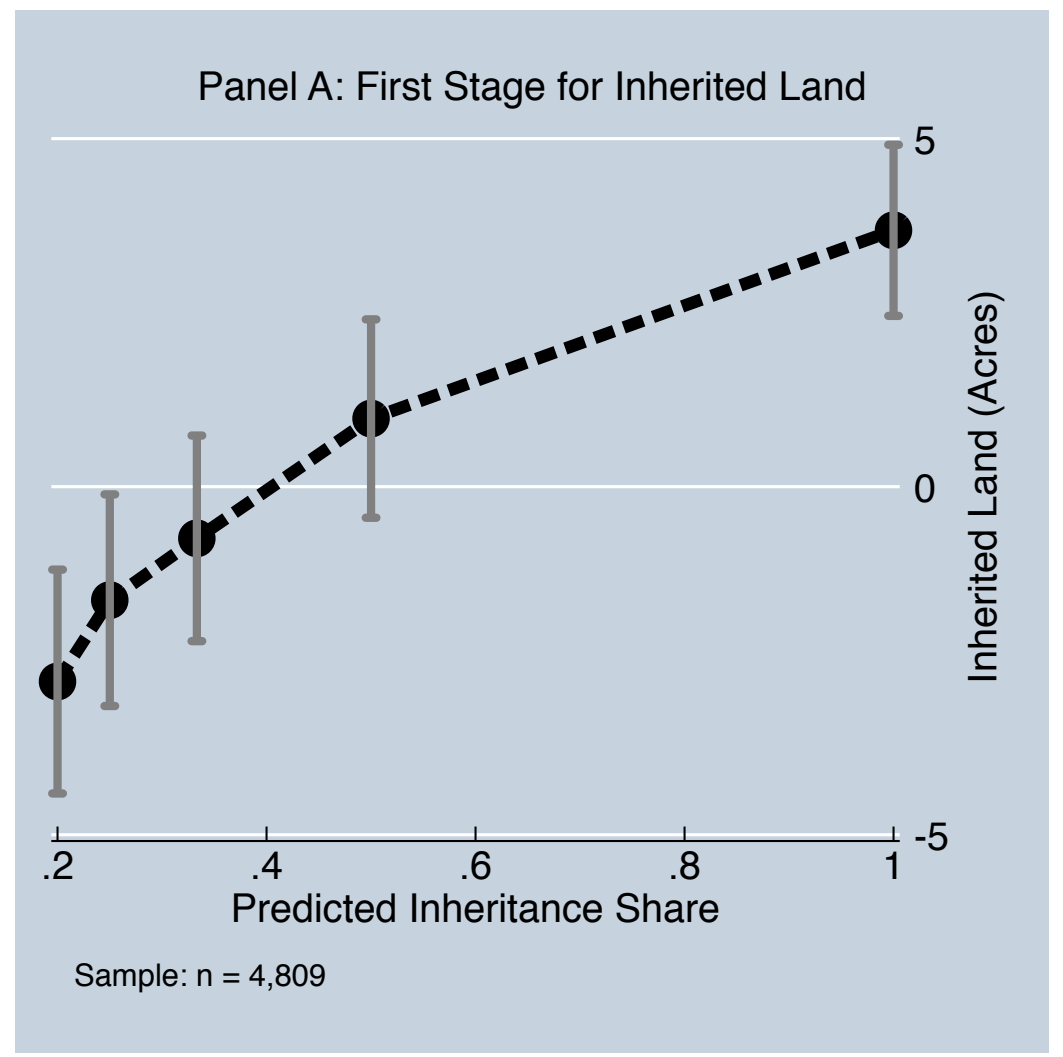

Notes:

This figure plots the first stage for inherited landholdings. For visual clarity, the figure limits the domain to those with less than or equal to 4 brothers $(94.7 \%$ of sample), i.e. predicted shares between 0.2 and 1 . The graphs plots the coefficients (black dots) from a regression of the dependent variable -- land inherited by the respondent measured in acreas -- on a set of dummy variables for each value of the inheritance share, omitting the constant. This regression includes district fixed effects (99 dummies), fixed effects for family landholdings (0-80+ acres, 5 acre intervals, 15 dummies) and the number of siblings (14 dummies). The $95 \%$ confidence interval is calculated using robust standard errors and is plotted with the gray bars. Data Source: ARIS-REDS Dataset. 
FIGURE 4: NON-PARAMETRIC VISUALIZATIONS OF REDUCED FORM EQUATIONS FOR OCCUPATIONAL CHOICE, CONSUMPTION AND MIGRATION
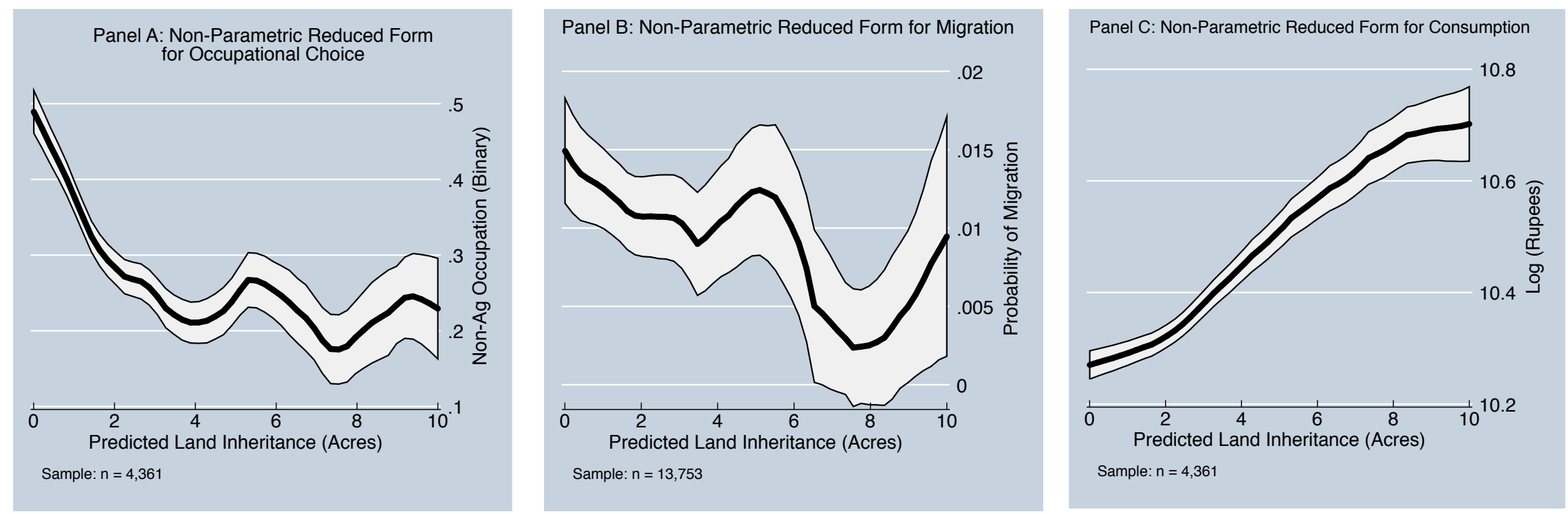

Notes:

These figures plot the reduced form for occupational choice (Panel A), urban migration (Panel B) and household consumption (Panel C). All figures plot smoothed values from kernel-weighted local polynomial regressions of the dependent variable in question on the predicted land instrument, which is equal to Family Land/(1+Brothers). All figures use the epanechnikov kernel with the STATA calculated rule of thumb (ROT) bandwidth. The white bands show the $95 \%$ confidence interval, which are calculated using the default normalized weighted residual sum of squares from a local polynomial fit of a higher order using a pilot bandwidth of $1.5 *$ ROT. All figures limit the domain to 10 acres which accounts for $90 \%$ of the sample. Data Source: ARIS-REDS Dataset. 


\section{FIGURE 5: NON-PARAMETRIC VISUALIZATIONS OF REDUCED FORM FOR CONSUMPTION BY BIRTH ORDER}
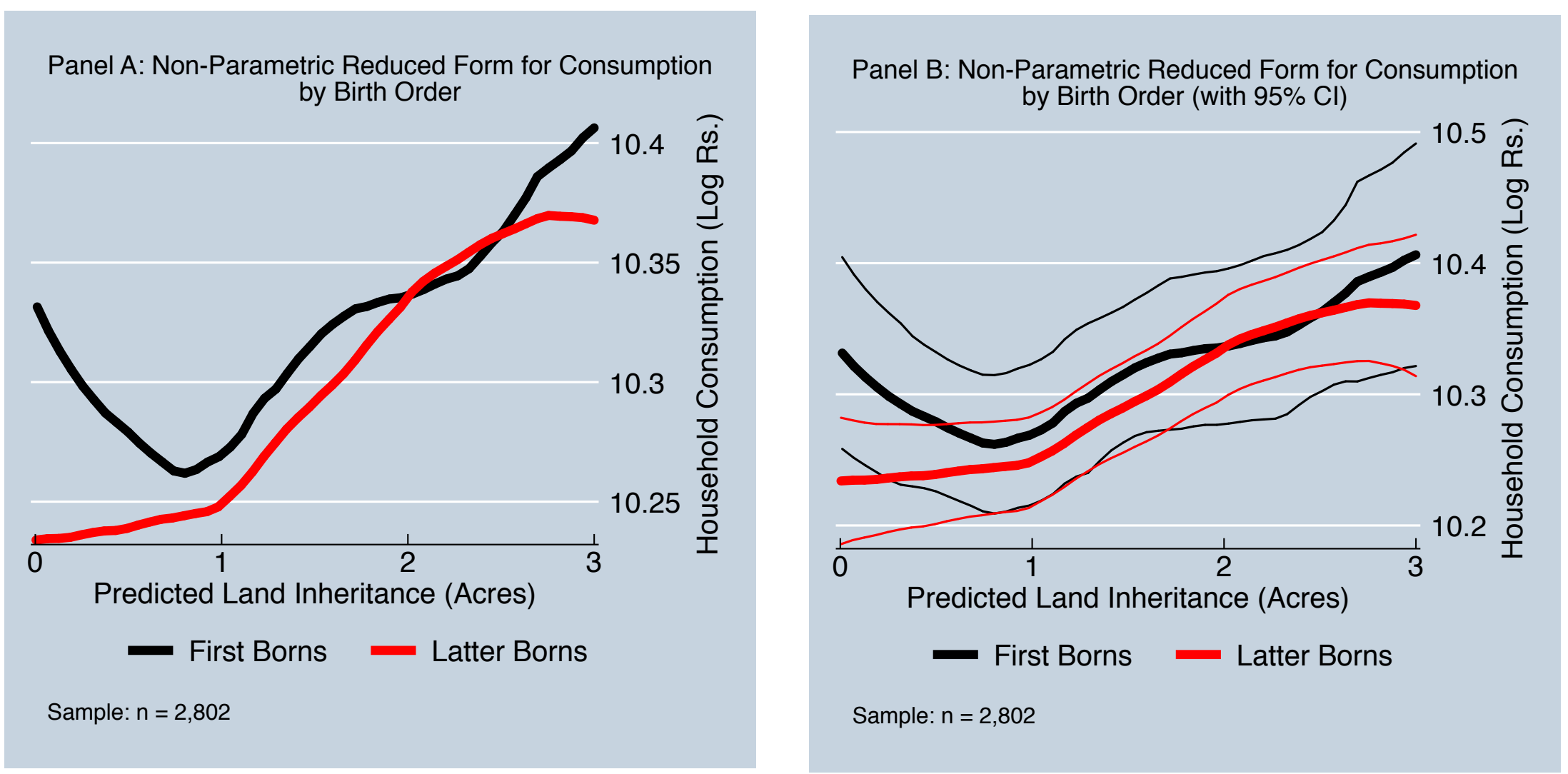

Notes:

These figures plots the reduced form for household consumption. All figures plot smoothed values from kernel-weighted local polynomial regressions of the dependent variable in question on the predicted land instrument, which is equal to Family Land/(1+Brothers). All figures use the epanechnikov kernel with the STATA calculated rule of thumb (ROT) bandwidth. Panel B includes the thinner bands which are the 95\% confidence interval. These are calculated using the default normalized weighted residual sum of squares from a local polynomial fit of a higher order using a pilot bandwidth of $1.5 *$ ROT. Both figures limit the domain to 3 acres which accounts for $58.3 \%$ of the sample. Data Source: ARIS-REDS Dataset. 
TABLE 1: SUMMARY STATISTICS FOR HEAD-LEVEL, SIBLING-LEVEL AND CHILD-LEVEL DATA

\begin{tabular}{|c|c|c|c|c|c|c|}
\hline \multirow[b]{2}{*}{ Dependent Variable } & \multicolumn{2}{|c|}{ Head-Level } & \multicolumn{2}{|c|}{ Sibling-Level } & \multicolumn{2}{|c|}{ Child-Level } \\
\hline & $\begin{array}{l}\text { Mean } \\
(1)\end{array}$ & $\begin{array}{l}\text { Standard } \\
\text { Deviation } \\
\text { (2) }\end{array}$ & $\begin{array}{l}\text { Mean } \\
\text { (3) }\end{array}$ & $\begin{array}{l}\text { Standard } \\
\text { Deviation } \\
\text { (4) }\end{array}$ & $\begin{array}{c}\text { Mean } \\
(5)\end{array}$ & $\begin{array}{c}\text { Standard } \\
\text { Deviation } \\
(6)\end{array}$ \\
\hline Age (Years) & 49.263 & 14.149 & 48.376 & 35.705 & 23.248 & 11.216 \\
\hline Sex & 1.000 & 0.000 & 1.000 & 0.000 & 0.549 & 0.498 \\
\hline Education (Years) & 5.847 & 5.253 & 4.623 & 4.386 & 5.481 & 4.709 \\
\hline Inherited Land & 0.791 & 0.406 & 0.674 & 0.469 & 0.033 & 0.179 \\
\hline Currently Owns Land & 0.926 & 0.262 & 0.766 & 0.423 & 0.322 & 0.467 \\
\hline Household Size & 6.257 & 3.447 & 5.085 & 2.887 & 4.015 & 4.360 \\
\hline Rural to Urban Migrant & - & - & 0.011 & 0.103 & 0.018 & 0.132 \\
\hline Non Agricultural Occupation & 0.298 & 0.458 & - & - & - & - \\
\hline Yearly HH Consumption (Rs.) & 42262.01 & 37895.06 & - & - & - & - \\
\hline Years since Headship Assumed & 15.961 & 13.776 & - & - & - & - \\
\hline Father of Head Alive & 0.187 & 0.390 & - & - & - & - \\
\hline Loan (Last 5 years) & 0.196 & 0.397 & - & - & - & - \\
\hline No. of Brothers & 1.925 & 1.432 & - & - & - & - \\
\hline No. of Siblings & 3.773 & 2.183 & - & - & - & - \\
\hline Predicted Share (0-1) & 0.452 & 0.265 & - & - & - & - \\
\hline First Born & 0.377 & 0.485 & - & - & - & - \\
\hline Inherited Land (Acres) & 4.120 & 6.734 & - & - & - & - \\
\hline Current Land (Acres) & 5.136 & 8.090 & - & - & - & - \\
\hline $\mathrm{N}$ & 4809 & - & 14773 & - & 16130 & - \\
\hline
\end{tabular}

Notes:

This table presents summary statistics for the data used from the 1999 Wave of the ARIS-REDS survey. Means are reported in columns 1,3 , and 5, while standard deviations are reported in columns 2,4 and 6 . Columns 1 and 2 contain summary statistics for all male Hindu household heads whose parents owned land. Column 3 and 4 contain summary statistics for sibling level data. The data examined here corresponds to all male siblings of household heads (including the head) used in the main analysis that reached the age of 10 prior to their death. Columns 5 and 6 contain summary statistics for child level data. This includes all children of household heads in the main analysis who are at least 6 years old (i.e. of schooling age). Data Source: ARIS-REDS Dataset. 
TABLE 2 : THE FIRST STAGE AND REDUCED FORM ESTIMATES

\begin{tabular}{|c|c|c|c|c|c|}
\hline Instrument Specification & $\begin{array}{c}\text { No. of Brothers } \\
\text { (Linear) } \\
(1) \\
\end{array}$ & $\begin{array}{c}\text { Pred Share } \\
(0-1) \\
(2) \\
\end{array}$ & $\begin{array}{c}\text { Pred Land } \\
\text { (Acres) } \\
(3) \\
\end{array}$ & $\begin{array}{c}\log (\text { Pred Land }) \\
\text { (Acres) } \\
(4) \\
\end{array}$ & $\begin{array}{c}\text { Brother Dummies } \\
\text { (5) }\end{array}$ \\
\hline \multicolumn{6}{|c|}{ Panel A: First stage for Inherited Land (Acres) } \\
\hline Instrument & $\begin{array}{c}-1.248 * * * \\
(0.110)\end{array}$ & $\begin{array}{c}7.174 * * * \\
(0.639)\end{array}$ & $\begin{array}{c}0.542 * * * \\
(0.054)\end{array}$ & $\begin{array}{c}1.757 * * * \\
(0.148)\end{array}$ & - \\
\hline 1 Brother & - & - & - & - & $\begin{array}{l}-2.704 * * * \\
(0.390)\end{array}$ \\
\hline 2 Brothers & - & - & - & - & $\begin{array}{l}-4.425 * * * \\
(0.444)\end{array}$ \\
\hline 3 Brothers & - & - & - & - & $\begin{array}{l}-5.313 * * * \\
(0.488)\end{array}$ \\
\hline 4 Brothers & - & - & - & - & $\begin{array}{l}-6.481 * * * \\
(0.559)\end{array}$ \\
\hline 5 Brothers & - & - & - & - & $\begin{array}{l}-6.689 * * * \\
(0.757)\end{array}$ \\
\hline $\begin{array}{l}\text { Depvar mean } \\
\text { First Stage F-Statistic } \\
\mathrm{N}\end{array}$ & $\begin{array}{c}4.120 \\
128.137 \\
4809\end{array}$ & $\begin{array}{c}4.120 \\
125.952 \\
4809\end{array}$ & $\begin{array}{c}4.120 \\
101.458 \\
4809\end{array}$ & $\begin{array}{c}4.120 \\
141.607 \\
4809\end{array}$ & $\begin{array}{l}4.120 \\
22.433 \\
4809\end{array}$ \\
\hline \multicolumn{5}{|c|}{ Panel B: Reduced form for Non-Agricultural Occupation } & - \\
\hline Instrument & $\begin{array}{c}0.025 * * * \\
(0.006)\end{array}$ & $\begin{array}{c}-0.126 * * * \\
(0.035)\end{array}$ & $\begin{array}{l}-0.001 \\
(0.001)\end{array}$ & $\begin{array}{c}-0.073 * * * \\
(0.011)\end{array}$ & - \\
\hline $\begin{array}{l}\text { Depvar Mean } \\
\mathrm{N}\end{array}$ & $\begin{array}{c}0.298 \\
4809\end{array}$ & $\begin{array}{c}0.298 \\
4809\end{array}$ & $\begin{array}{c}0.298 \\
4809\end{array}$ & $\begin{array}{c}0.298 \\
4809\end{array}$ & - \\
\hline \multicolumn{6}{|c|}{ Panel C: Reduced form for Log(Household Consumption) } \\
\hline Instrument & $\begin{array}{c}-0.041 * * * \\
(0.008)\end{array}$ & $\begin{array}{c}0.195 * * * \\
(0.043)\end{array}$ & $\begin{array}{c}0.012 * * * \\
(0.002)\end{array}$ & $\begin{array}{c}0.091 * * * \\
(0.013)\end{array}$ & - \\
\hline $\begin{array}{l}\text { Depvar Mean } \\
\mathrm{N}\end{array}$ & $\begin{array}{c}10.442 \\
4809\end{array}$ & $\begin{array}{c}10.442 \\
4809\end{array}$ & $\begin{array}{c}10.442 \\
4809\end{array}$ & $\begin{array}{c}10.442 \\
4809\end{array}$ & - \\
\hline $\begin{array}{l}\text { No. of Siblings FE } \\
\text { Family Land FE } \\
\text { District FE }\end{array}$ & $\begin{array}{l}\mathrm{Y} \\
\mathrm{Y} \\
\mathrm{Y}\end{array}$ & $\begin{array}{l}\mathrm{Y} \\
\mathrm{Y} \\
\mathrm{Y}\end{array}$ & $\begin{array}{l}\mathrm{Y} \\
\mathrm{Y} \\
\mathrm{Y}\end{array}$ & $\begin{array}{l}\mathrm{Y} \\
\mathrm{Y} \\
\mathrm{Y}\end{array}$ & $\begin{array}{l}\mathrm{Y} \\
\mathrm{Y} \\
\mathrm{Y}\end{array}$ \\
\hline
\end{tabular}

Notes:

The sample is restricted to Hindu male household heads whose parents owned land in the 1999 ARIS-REDS's survey. The data is at the household head level. Panel A reports the coefficient on the instrument(s) for the first stage. Panel B reports the coefficient on the instrument from reduced form regression for non-agricultural occupation, while Panel $\mathrm{C}$ reports the reduced form for the $\log$ of household consumption. In column 1 the instrument is specified as the (linear) number of brothers, in column 2 it is 'Predicted Share' $=1 /(1+$ Brothers $)$, in column 3 it is 'Predicted Land' = Family Land/( $1+$ Brothers $)$, in column 4 it is $\log$ (Predicted Land), and in column 5 it is the a set of dummies for the number of brothers ( 8 dummies in total, I report the coefficients for up to 5 brothers which account for $98.11 \%$ of sample). The dependent variable Panel B is Non-Ag occupation and is defined as the primary status reported by the respondent in the REDS survey. The variable is coded as 0 if this is self-cultivation or agricultural labor and 1 otherwise. The dependent variable in Panel B is the natural logarithm of yearly household consumption. This includes food and non-food items, and values home production at village-specific market prices. Brothers are defined as male siblings who grew up to at least the age of 10. The F-stat reported is the partial F-statistic for the instrument(s) ( Cragg-Donald Wald F-statistic). Robust standard errors are given in parentheses, asterisks denote significance: $* \mathrm{p}<0.10, * * \mathrm{p}<0.05, * * * \mathrm{p}<0.01$ Data Source: ARIS-REDS Dataset. 


\section{TABLE 3 : THE EFFECT OF INHERITED LAND ON OCCUPATIONAL CHOICE, MIGRATION AND HOUSEHOLD CONSUMPTION}

\begin{tabular}{|c|c|c|c|c|c|c|}
\hline \multirow[t]{2}{*}{$\overline{\text { Dependent Variable }}$} & \multicolumn{2}{|c|}{$\begin{array}{c}\text { Non-Ag Occupation } \\
\text { Binary Variable }\end{array}$} & \multicolumn{2}{|c|}{$\begin{array}{c}\text { Rural-Urban Migration } \\
\text { Binary Variable }\end{array}$} & \multicolumn{2}{|c|}{$\begin{array}{c}\text { Household Consumption } \\
\log (\text { Rs.) }\end{array}$} \\
\hline & $\begin{array}{l}\text { OLS } \\
(1) \\
\end{array}$ & $\begin{array}{c}\text { 2SLS } \\
(2)\end{array}$ & $\begin{array}{l}\text { OLS } \\
(3)\end{array}$ & $\begin{array}{c}\text { 2SLS } \\
(4)\end{array}$ & $\begin{array}{l}\text { OLS } \\
(5)\end{array}$ & $\begin{array}{l}\text { 2SLS } \\
(6)\end{array}$ \\
\hline \multicolumn{7}{|l|}{ Panel A: Full Sample } \\
\hline $\begin{array}{l}\text { Inherited Land } \\
\text { (Acres) }\end{array}$ & $\begin{array}{c}-0.003 * * \\
(0.001)\end{array}$ & $\begin{array}{c}-0.018 * * * \\
(0.005)\end{array}$ & $\begin{array}{l}-0.000 \\
(0.000)\end{array}$ & $\begin{array}{c}-0.002 * * * \\
(0.001)\end{array}$ & $\begin{array}{c}0.025 * * * \\
(0.003)\end{array}$ & $\begin{array}{c}0.027 * * * \\
(0.006)\end{array}$ \\
\hline Mean of Dep. Var. & 0.298 & 0.298 & 0.011 & 0.011 & 10.442 & 10.442 \\
\hline First Stage F-statistic & - & 125.952 & - & 186.771 & - & 125.952 \\
\hline $\mathrm{N}$ & 4809 & 4809 & 14773 & 14773 & 4809 & 4809 \\
\hline \multicolumn{7}{|c|}{ Panel B: Family Landholdings Below First Quartile (less than 3 acres) } \\
\hline $\begin{array}{l}\text { Inherited Land } \\
\text { (Acres) }\end{array}$ & $\begin{array}{c}-0.030 * * * \\
(0.011)\end{array}$ & $\begin{array}{c}-0.210 * * * \\
(0.069)\end{array}$ & $\begin{array}{c}-0.000 * * \\
(0.000)\end{array}$ & $\begin{array}{l}-0.034 * \\
(0.021)\end{array}$ & $\begin{array}{c}0.055 * * * \\
(0.014)\end{array}$ & $\begin{array}{c}0.080 \\
(0.064)\end{array}$ \\
\hline Mean of Dep. Var. & 0.414 & 0.414 & 0.016 & 0.016 & 10.244 & 10.244 \\
\hline First Stage F-statistic & - & 22.690 & - & 6.881 & - & 22.690 \\
\hline $\mathrm{N}$ & 1363 & 1363 & 3720 & 3720 & 1363 & 1363 \\
\hline No. of Siblings FE & $\mathrm{Y}$ & $\mathrm{Y}$ & $\mathrm{Y}$ & $\mathrm{Y}$ & $\mathrm{Y}$ & $\mathrm{Y}$ \\
\hline Family Land FE & Y & Y & Y & Y & Y & Y \\
\hline District FE & Y & $\mathrm{Y}$ & Y & $\mathrm{Y}$ & Y & $\mathrm{Y}$ \\
\hline Data & \multicolumn{2}{|c|}{ Head-Level } & \multicolumn{2}{|c|}{ Sibling-Level } & \multicolumn{2}{|c|}{ Head-Level } \\
\hline
\end{tabular}

Notes:

This table reports estimates of the long-term effect of inherited land on occupational choice, migration and household consumption. Columns 1, 3 and 5 report OLS coeffiient estimates while columns 2, 4 and 6 report 2SLS estimates. The sample in columns 1,2,5 and 6 is restricted to Hindu male household heads whose parents owned land in the 1999 ARIS-REDS's survey. The data is at the household head level. The sample in column 3 and 4 are all male siblings of these household heads (including the heads) aged above 10 years. Note, this data is reported for all siblings not just siblings residing in the household at the time of the survey. Panel A includes all households, while Panel B limits the analysis to households whose family had less than 3 acres. The dependent variable in cols 1 and 2 is Non-Ag occupation and is defined as the primary status reported by the respondent in the REDS survey. The variable is coded as 0 if this is self-cultivation or agricultural labor and 1 otherwise. The dependent variable in column 3 and 4 is a dummy variable for whether or not the sibling migrated to an urban area in the same district or outside of it. The dependent variable col 5 and 6 is the natural logarithm of yearly household consumption. This includes food and non-food items, and values home production at village-specific market prices. All specifications include district fixed effects ( 99 dummies), fixed effects for family landholdings (0-80+ acres, 5 acre intervals, 15 dummies) and the number of siblings (14 dummies). The excluded group are heads who are only children from West Godavari district in Andhra Pradesh with family landholdings between 0-5 acres. The instrument specfication used is Predicted Share $=1 /(1+$ Brothers). The F-stat reported is the partial F-statistic for the instrument(s) ( CraggDonald Wald F-statistic). Robust standard errors are given in parentheses, asterisks denote significance: $* \mathrm{p}<0.10, * * \mathrm{p}<0.05, * * *$ $\mathrm{p}<0.01$ Standard errors are clustered at the family level for sibling-level regressions. Data Source: ARIS-REDS Dataset. 
TABLE 4: THE EFFECT OF INHERITED LAND ON BORROWING (2SLS ESTIMATES)

\begin{tabular}{|c|c|c|c|c|}
\hline \multirow[t]{2}{*}{$\overline{\text { Dependent Variable }}$} & \multicolumn{2}{|c|}{$\begin{array}{l}\text { Took out Loan (Last } 5 \text { yrs) } \\
\text { Binary Variable }\end{array}$} & \multicolumn{2}{|c|}{$\begin{array}{l}\text { Total Value of Loans } \\
\text { Log(Rs.) }\end{array}$} \\
\hline & $\begin{array}{l}\text { OLS } \\
(1)\end{array}$ & $\begin{array}{c}\text { 2SLS } \\
(2)\end{array}$ & $\begin{array}{l}\text { OLS } \\
(3)\end{array}$ & $\begin{array}{c}\text { 2SLS } \\
(4)\end{array}$ \\
\hline $\begin{array}{l}\text { Inherited Land } \\
\text { (Acres) }\end{array}$ & $\begin{array}{r}0.002 * * \\
(0.001)\end{array}$ & $\begin{array}{c}0.015 * * * \\
(0.004)\end{array}$ & $\begin{array}{c}0.030^{* * *} \\
(0.009)\end{array}$ & $\begin{array}{c}0.152 * * * \\
(0.036)\end{array}$ \\
\hline No. of Siblings FE & $\mathrm{Y}$ & Y & $\mathrm{Y}$ & Y \\
\hline Family Land FE & Y & Y & $\mathrm{Y}$ & Y \\
\hline District FE & Y & Y & $\mathrm{Y}$ & Y \\
\hline Mean of Dep. Var. & 0.184 & 0.184 & 1.700 & 1.700 \\
\hline $\begin{array}{l}\text { First Stage F-statistic } \\
\mathrm{N}\end{array}$ & $\begin{array}{c}- \\
4809\end{array}$ & $\begin{array}{c}125.952 \\
4809\end{array}$ & $\begin{array}{c}- \\
4809\end{array}$ & $\begin{array}{c}125.952 \\
4809\end{array}$ \\
\hline
\end{tabular}

Notes:

This table reports estimates of the long-term effect of inherited land on access to credit. Columns 1 and 3 report OLS coefficient estimates while columns 2 and 4 report 2SLS estimates. The sample is restricted to Hindu male household heads whose parents owned land in the 1999 ARIS-REDS's survey. The data is at the household head level. The dependent variable in col 1-2 is a dummy variable coded as 1 if the head took out a loan in the past 5 years, while in col 3-4 it is the log of the total value of all loans taken out in the last 5 years. All specifications include district fixed effects ( 99 dummies), fixed effects for family landholdings (0-80+ acres, 5 acre intervals, 15 dummies) and the number of siblings (14 dummies). The excluded group are heads who are only children from West Godavari district in Andhra Pradesh with family landholdings between 0-5 acres. The instrument specfication used here is Predicted Share $=1 /$ (1+ Brothers). The F-stat reported is the partial F-statistic for the instrument(s) ( Cragg-Donald Wald Fstatistic). Robust standard errors are given in parentheses, asterisks denote significance: ${ }^{*} \mathrm{p}<0.10,{ }^{*} *$ $\mathrm{p}<0.05, * * * \mathrm{p}<0.01$ Data Source: ARIS-REDS Dataset. 
TABLE 5: HETEROGENEOUS EFFECTS OF INHERITED LAND BY BIRTH ORDER (2SLS ESTIMATES)

\begin{tabular}{|c|c|c|c|c|c|c|c|}
\hline Dependent Variable & $\begin{array}{c}\text { Non-Ag } \\
\text { Occupation } \\
\text { Binary } \\
(1) \\
\end{array}$ & $\begin{array}{c}\text { Ag Labor } \\
\text { Total Man days } \\
\text { (2) }\end{array}$ & $\begin{array}{l}\text { Hired Ag } \\
\text { Labor } \\
\text { Log(Rs.) } \\
(3) \\
\end{array}$ & $\begin{array}{c}\text { Land } \\
\text { Improvement } \\
\text { Log(Rs.) } \\
(4) \\
\end{array}$ & $\begin{array}{c}\text { Nonfarm Labor } \\
\text { Total Man days } \\
(5)\end{array}$ & $\begin{array}{l}\text { Rural-Urban } \\
\text { Migration } \\
\text { Binary } \\
(6) \\
\end{array}$ & $\begin{array}{l}\text { Household } \\
\text { Consumption } \\
\text { Log(Rs.) } \\
(7) \\
\end{array}$ \\
\hline Land & $\begin{array}{l}-0.002 \\
(0.006)\end{array}$ & $\begin{array}{l}1.231^{* * * *} \\
(0.402)\end{array}$ & $\begin{array}{c}0.174 * * * \\
(0.047)\end{array}$ & $\begin{array}{l}-0.014 \\
(0.023)\end{array}$ & $\begin{array}{c}0.430 \\
(0.989)\end{array}$ & $\begin{array}{l}-0.001 \\
(0.001)\end{array}$ & $\begin{array}{c}0.034 * * * \\
(0.007)\end{array}$ \\
\hline First Born & $\begin{array}{l}0.180 * * * \\
(0.057)\end{array}$ & $\begin{array}{l}-6.710^{*} \\
(3.670)\end{array}$ & $\begin{array}{c}-0.926^{* *} \\
(0.449)\end{array}$ & $\begin{array}{c}-0.454 * * \\
(0.228)\end{array}$ & $\begin{array}{l}15.377 \\
(9.352)\end{array}$ & $\begin{array}{c}0.009 \\
(0.007)\end{array}$ & $\begin{array}{c}0.172 * * * \\
(0.063)\end{array}$ \\
\hline Land*First Born & $\begin{array}{c}-0.044 * * * \\
(0.014)\end{array}$ & $\begin{array}{l}1.700 * \\
(0.886)\end{array}$ & $\begin{array}{l}0.210^{*} \\
(0.109)\end{array}$ & $\begin{array}{l}0.120 * * \\
(0.055)\end{array}$ & $\begin{array}{c}-4.530 * * \\
(2.182)\end{array}$ & $\begin{array}{l}-0.003^{*} \\
(0.002)\end{array}$ & $\begin{array}{c}-0.029 * * \\
(0.015)\end{array}$ \\
\hline $\begin{array}{l}\text { No. of Siblings FE } \\
\text { Age FE } \\
\text { Family Land FE } \\
\text { District FE }\end{array}$ & $\begin{array}{l}\mathrm{Y} \\
\mathrm{Y} \\
\mathrm{Y} \\
\mathrm{Y}\end{array}$ & $\begin{array}{l}\mathrm{Y} \\
\mathrm{Y} \\
\mathrm{Y} \\
\mathrm{Y}\end{array}$ & $\begin{array}{l}\mathrm{Y} \\
\mathrm{Y} \\
\mathrm{Y} \\
\mathrm{Y}\end{array}$ & $\begin{array}{l}\mathrm{Y} \\
\mathrm{Y} \\
\mathrm{Y} \\
\mathrm{Y}\end{array}$ & $\begin{array}{l}\mathrm{Y} \\
\mathrm{Y} \\
\mathrm{Y} \\
\mathrm{Y}\end{array}$ & $\begin{array}{l}\mathrm{Y} \\
\mathrm{Y} \\
\mathrm{Y} \\
\mathrm{Y}\end{array}$ & $\begin{array}{l}\mathrm{Y} \\
\mathrm{Y} \\
\mathrm{Y} \\
\mathrm{Y}\end{array}$ \\
\hline $\begin{array}{l}\text { Depvar Mean } \\
\text { First Stage F-Stat }\end{array}$ & $\begin{array}{c}0.298 \\
27.390\end{array}$ & $\begin{array}{l}28.981 \\
27.390\end{array}$ & $\begin{array}{c}4.758 \\
27.390\end{array}$ & $\begin{array}{c}0.925 \\
27.390\end{array}$ & $\begin{array}{l}23.145 \\
27.390\end{array}$ & $\begin{array}{l}0.011 \\
42.46\end{array}$ & $\begin{array}{l}10.442 \\
27.390\end{array}$ \\
\hline $\mathrm{N}$ & 4809 & 4809 & 4809 & 4809 & 4809 & 14773 & 4809 \\
\hline Data & Head-Level & Head-Level & Head-Level & Head-Level & Head-Level & Sibling-Level & Head-Level \\
\hline
\end{tabular}

Notes:

This table tests whether the effect of inherited land on occupational choice, children's migration and household consumption vary by birth order and the amount of land inherited. All coefficients reported are 2SLS estimates. The sample is restricted to Hindu male household heads whose parents owned land in the 1999 ARIS-REDS's survey. The data is at the household head level. The sample in column 3 and 4 are all male siblings of these household heads (including the heads) aged above 10 years. Note, this data is reported for all siblings not just siblings residing in the household at the time of the survey. Each column reports the 2 SLS coefficients on inherited land, first born - a dummy coded as 1 if the respondent was the first born child in his family - and their interaction. The two endogenous variables are instrumented with two instruments : Predicted Share $=(1 / 1+$ Brothers $)$ and the interaction between Predicted Share and First Born. Non-Ag occupation (col 1$)$ is defined as the primary status reported by the respondent in the REDS survey. The variable is coded as 0 if this is self-cultivation or agricultural labor and 1 otherwise. 'Ag labor' (col 2 ) are the total number of days of agricultural labor performed by the head in the prior season. 'Hired Ag Labor' (col 3) is the log of the value of hired agricultural labor. Land improvement ( $\mathrm{col} 4)$ is the log of the total expenditure on improvements in land (e.g. terracing, bunding, fencing, leveling, reclamation etc...) undertaken in the last 10 years. Non farm labor' (col 5) is the total number of days of labor in a non-farm enterprise in the prior season. The dependent variable in column 6 is dummy variable for whether or not the sibling migrated to an urban area within the district or outside it. The dependent variable col 7 is the natural logarithm of yearly household consumption. This includes food and non-food items, and values home production at village-specific market prices. All specifications include district fixed effects (99 dummies), fixed effects for family landholdings (0-80+ acres, 5 acre intervals, 15 dummies), age of the household head (20-100, 5 year intervals, 15 dummies) and the number of siblings (14 dummies). The excluded group are heads who are only children, aged 20-25 from West Godavari district in Andhra Pradesh with family landholdings between 0-5 acres. The specification involving child-level data (column 6) includes a dummy for the sex of the child. The F-stat reported is the partial F-statistic for the instrument(s) ( Cragg-Donald Wald F-statistic). Robust standard errors are given in parentheses, asterisks denote significance: $*$ p $<0.10, * *$ $\mathrm{p}<0.05, * * * \mathrm{p}<0.01$. Standard errors are clustered at the family for child-level regressions. Data Source: ARIS-REDS Dataset. 


\section{TABLE 6: THE EFFECT OF PARENT'S INHERITED LAND ON CHILD OUTCOMES BY BIRTHODER (2SLS ESTIMATES)}

\begin{tabular}{|c|c|c|c|c|}
\hline \multirow[t]{2}{*}{ Dependent Variable } & \multicolumn{2}{|c|}{$\begin{array}{c}\text { Education } \\
\text { (Years) }\end{array}$} & \multicolumn{2}{|c|}{$\begin{array}{c}\text { Rural-Urban Migration } \\
\text { (Binary) }\end{array}$} \\
\hline & $(1)$ & $(2)$ & (3) & (4) \\
\hline $\begin{array}{l}\text { Inherited Land } \\
\text { (Acres) }\end{array}$ & $\begin{array}{l}0.073 * * \\
(0.036)\end{array}$ & $\begin{array}{c}0.091 * * \\
(0.038)\end{array}$ & $\begin{array}{l}-0.001 \\
(0.002)\end{array}$ & $\begin{array}{l}-0.000 \\
(0.001)\end{array}$ \\
\hline First Born & - & $\begin{array}{l}0.451 * \\
(0.245)\end{array}$ & - & $\begin{array}{c}0.013 \\
(0.008)\end{array}$ \\
\hline Land*First Born & - & $\begin{array}{l}-0.075 \\
(0.054)\end{array}$ & - & $\begin{array}{c}-0.004 * * \\
(0.002)\end{array}$ \\
\hline Age FE & $\mathrm{Y}$ & $\mathrm{Y}$ & $\mathrm{Y}$ & $\mathrm{Y}$ \\
\hline Sex FE & $\mathrm{Y}$ & $\mathrm{Y}$ & $\mathrm{Y}$ & $\mathrm{Y}$ \\
\hline No. of Siblings FE & $\mathrm{Y}$ & $\mathrm{Y}$ & $\mathrm{Y}$ & $\mathrm{Y}$ \\
\hline Family Land FE & $\mathrm{Y}$ & $\mathrm{Y}$ & Y & $\mathrm{Y}$ \\
\hline District FE & $\mathrm{Y}$ & $\mathrm{Y}$ & $\mathrm{Y}$ & $\mathrm{Y}$ \\
\hline Mean of Dep. Var. & 5.481 & 5.481 & 0.018 & 0.018 \\
\hline First Stage F-statistic & 157.903 & 37.047 & 157.903 & 37.047 \\
\hline $\mathrm{N}$ & 16130 & 16130 & 16130 & 16130 \\
\hline
\end{tabular}

Notes:

This table reports estimates of the long-term effect of inherited land on the education and migration of children of household heads by child birth order. The sample is restricted to all children of Hindu male household heads whose parents owned land in the 1999 ARISREDS's survey. The data is at the child- level. The dependent variable in cols 1-2 is the years of education of the child. The dependent variable in cols 3-4 is a dummy variable for whether or not the child migrated to an urban area within the district or outside it. All specifications include district fixed effects (99 dummies), fixed effects for family landholdings (0-80+ acres, 5 acre intervals, 15 dummies) and the number of siblings (14 dummies). The excluded group are heads who are only children from West Godavari district in Andhra Pradesh with family landholdings between 0-5 acres. The instrument specfication used here is Predicted Share $=1 /(1+$ Brothers $)$. The F-stat reported is the partial F-statistic for the instrument(s) ( Cragg-Donald Wald F-statistic). Robust standard errors are clustered at the family-level and are shown in parentheses, asterisks denote significance: $* \mathrm{p}<0.10, * * \mathrm{p}<0.05, * * * \mathrm{p}<0.01$. Data Source: ARIS-REDS Dataset. 
TABLE 7: HETEROGENEOUS EFFECTS OF INHERITED LAND BY TRANSACTION COSTS IN THE MARKET FOR LAND (2SLS ESTIMATES)

\begin{tabular}{|c|c|c|c|c|}
\hline Dependent Variable & $\begin{array}{c}\text { Non-Ag } \\
\text { Occupation } \\
\text { Binary } \\
(1) \\
\end{array}$ & $\begin{array}{l}\text { HH Consumption } \\
\qquad \begin{array}{c}\log (\text { Rs. }) \\
(2)\end{array}\end{array}$ & $\begin{array}{c}\text { Non-Ag } \\
\text { Occupation } \\
\text { Binary } \\
(3) \\
\end{array}$ & $\begin{array}{l}\text { HH Consumption } \\
\begin{array}{c}\log (\text { Rs. }) \\
(4)\end{array}\end{array}$ \\
\hline Land & $\begin{array}{c}-0.024 * * \\
(0.010)\end{array}$ & $\begin{array}{c}0.032 * * * \\
(0.003)\end{array}$ & $\begin{array}{l}-0.011 \\
(0.010)\end{array}$ & $\begin{array}{c}0.030 * * * \\
(0.010)\end{array}$ \\
\hline Transaction Cost & $\begin{array}{c}0.005 \\
(0.048)\end{array}$ & $\begin{array}{c}0.019 \\
(0.024)\end{array}$ & $\begin{array}{l}0.080^{*} \\
(0.048)\end{array}$ & $\begin{array}{c}-0.109 * * \\
(0.053)\end{array}$ \\
\hline Land $*$ Cost & $\begin{array}{l}-0.003 \\
(0.011)\end{array}$ & $\begin{array}{c}-0.008 * * \\
(0.003)\end{array}$ & $\begin{array}{c}-0.024 * * \\
(0.011)\end{array}$ & $\begin{array}{c}0.001 \\
(0.012)\end{array}$ \\
\hline $\begin{array}{l}\text { No. of Siblings FE } \\
\text { Family Land FE } \\
\text { District FE }\end{array}$ & $\begin{array}{l}\mathrm{Y} \\
\mathrm{Y} \\
\mathrm{Y}\end{array}$ & $\begin{array}{l}\mathrm{Y} \\
\mathrm{Y} \\
\mathrm{Y}\end{array}$ & $\begin{array}{l}\mathrm{Y} \\
\mathrm{Y} \\
\mathrm{Y}\end{array}$ & $\begin{array}{l}\mathrm{Y} \\
\mathrm{Y} \\
\mathrm{Y}\end{array}$ \\
\hline Depvar Mean & 0.298 & 10.442 & 0.298 & 10.442 \\
\hline $\begin{array}{l}\text { Transaction Costs } \\
\text { Measure }\end{array}$ & \multicolumn{2}{|c|}{ Transaction Costs Index (z-score) } & Additional & Registration Fees (Dummy) \\
\hline $\begin{array}{l}\text { First Stage F-Stat } \\
\mathrm{N}\end{array}$ & $\begin{array}{c}46.624 \\
4809\end{array}$ & $\begin{array}{c}46.624 \\
4809\end{array}$ & $\begin{array}{c}37.168 \\
4809\end{array}$ & $\begin{array}{c}37.168 \\
4809\end{array}$ \\
\hline
\end{tabular}

Notes:

This table tests whether the long-term effects of inherited land on occupational choice and household consumption vary with measures of transaction costs in the market for land. All coefficients reported are 2SLS estimates. The sample is restricted to Hindu male household heads whose parents owned land in the 1999 ARIS-REDS's survey. The data is at the household head level. Each column reports the 2SLS coefficients on inherited land, a measure of transaction costs in the market for land, and their interaction. The two endogenous variables are instrumented with two instruments: Predicted Share $=(1 / 1+$ Brothers $)$ and the interaction between Predicted Share and the measure of transaction costs. The dependent variable col $2 \& 4$ is the natural logarithm of yearly household consumption. This includes food and nonfood items, and values home production at village-specific market prices. Non-Ag occupation (cols $1 \& 3$ ) is defined as the primary status reported by the respondent in the REDS survey. The variable is coded as 0 if this is self-cultivation or agricultural labor and 1 otherwise. In cols $1 \& 2$ the measure of transaction costs is a $\mathrm{z}$-score that combines 7 measures of transaction costs in the market for land that vary at the village level in 1999. This index includes fees for registering a landholdings, the cost of a Record of Rights certificate (RoR), the travel time taken to get to the registrar's office, the number of days taken for registration, a dummy coded as 1 if the RoR cannot be obtained in the village or tehsil/taluka of residence (i.e. administrative block), stamp duty paid for registration, and a dummy for whether there are additional registration fees. A z-score is computed for each component of this index (across villages) and the average $\mathrm{z}$-score is the 'Transaction Costs Index'. In cols $3 \& 4$ the measure of transaction costs are whether there are additional fees that need to be paid in order to register one's landholdings in the village. Out of 246 villages, $60 \%$ have additional registration fees which on average amount to Rs. 1,019.83 ( \$20 in 1999). All specifications include district fixed effects (99 dummies), fixed effects for family landholdings ( $0-80+$ acres, 5 acre intervals, 15 dummies) and the number of siblings (14 dummies). The specifications also included a control for distance to the closest town $(\mathrm{km})$ and the interaction between this and landholdings. The excluded group are heads who are only children, from West Godavari district in Andhra Pradesh with family landholdings between 0-5 acres. The F-stat reported is the partial F-statistic for the instrument(s) ( Cragg-Donald Wald F-statistic). Robust standard errors are given in parentheses, asterisks denote significance: $* \mathrm{p}<0.10, * * \mathrm{p}<0.05, * * * \mathrm{p}<0.01$. Data Source: ARIS-REDS Dataset. 
TABLE 8: BALANCE CHECK FOR INSTRUMENT

\begin{tabular}{|c|c|c|c|c|c|c|}
\hline Dependent Variable & $\begin{array}{c}\text { Mean/ S.D. } \\
\text { Full Sample } \\
\text { (1) }\end{array}$ & $\begin{array}{r}\text { Coe } \\
2 \text { siblings } \\
(2)\end{array}$ & $\begin{array}{l}\operatorname{Rec} \\
\text { icient on In } \\
3 \text { siblings } \\
\text { (3) }\end{array}$ & $\begin{array}{l}\text { ed Form Es } \\
\text { ument } \dagger \text { by } \\
4 \text { siblings } \\
\text { (4) }\end{array}$ & $\begin{array}{l}\text { mates } \\
\text { ibling Coho } \\
5 \text { siblings } \\
(5) \\
\end{array}$ & $\begin{array}{l}\text { Size } \\
\text { Full Sample } \\
\quad(6)\end{array}$ \\
\hline Age of Head & $\begin{array}{l}49.263 \\
14.149\end{array}$ & $\begin{array}{l}-1.138 \\
(2.460)\end{array}$ & $\begin{array}{l}6.058 * * \\
(2.742)\end{array}$ & $\begin{array}{l}-3.261 \\
(3.198)\end{array}$ & $\begin{array}{c}3.191 \\
(3.740)\end{array}$ & $\begin{array}{c}0.947 \\
(1.085)\end{array}$ \\
\hline $\begin{array}{l}\text { Father's Education } \\
\text { (Years) }\end{array}$ & $\begin{array}{l}1.428 \\
2.759\end{array}$ & $\begin{array}{c}0.202 \\
(0.421)\end{array}$ & $\begin{array}{c}-0.860 * * \\
(0.414)\end{array}$ & $\begin{array}{c}0.567 \\
(0.671)\end{array}$ & $\begin{array}{c}0.063 \\
(0.788)\end{array}$ & $\begin{array}{c}0.103 \\
(0.205)\end{array}$ \\
\hline $\begin{array}{l}\text { Mother's Education } \\
\text { (Years) }\end{array}$ & $\begin{array}{l}0.407 \\
1.440\end{array}$ & $\begin{array}{c}0.198 \\
(0.187)\end{array}$ & $\begin{array}{l}-0.314^{*} \\
(0.163)\end{array}$ & $\begin{array}{l}0.610 * \\
(0.319)\end{array}$ & $\begin{array}{c}0.343 \\
(0.455)\end{array}$ & $\begin{array}{c}0.146 \\
(0.102)\end{array}$ \\
\hline $\begin{array}{l}\text { Father in Agriculture } \\
\text { (Primary Occupation) }\end{array}$ & $\begin{array}{l}0.866 \\
0.340\end{array}$ & $\begin{array}{c}0.021 \\
(0.062)\end{array}$ & $\begin{array}{c}0.027 \\
(0.067)\end{array}$ & $\begin{array}{c}0.105 \\
(0.096)\end{array}$ & $\begin{array}{l}-0.017 \\
(0.082)\end{array}$ & $\begin{array}{c}0.008 \\
(0.027)\end{array}$ \\
\hline $\begin{array}{l}\text { Dowry Received } \\
\text { Log(Rs. +1) }\end{array}$ & $\begin{array}{l}4.929 \\
3.977\end{array}$ & $\begin{array}{c}0.159 \\
(0.578)\end{array}$ & $\begin{array}{l}-0.073 \\
(0.631)\end{array}$ & $\begin{array}{l}-0.726 \\
(0.828)\end{array}$ & $\begin{array}{c}-1.703 * * \\
(0.794)\end{array}$ & $\begin{array}{l}-0.377 \\
(0.261)\end{array}$ \\
\hline $\begin{array}{l}\text { Age when Headship Assumed } \\
\text { (Years) }\end{array}$ & $\begin{array}{c}33.397 \\
9.988\end{array}$ & $\begin{array}{l}-1.939 \\
(1.786)\end{array}$ & $\begin{array}{c}0.804 \\
(1.902)\end{array}$ & $\begin{array}{l}-6.436 * * \\
(2.736)\end{array}$ & $\begin{array}{l}-3.547 \\
(2.725)\end{array}$ & $\begin{array}{l}-1.450^{*} \\
(0.790)\end{array}$ \\
\hline $\begin{array}{l}\text { Age of Marriage } \\
\text { (Years) }\end{array}$ & $\begin{array}{c}22.193 \\
5.173\end{array}$ & $\begin{array}{l}-1.103 \\
(0.761)\end{array}$ & $\begin{array}{c}0.693 \\
(0.797)\end{array}$ & $\begin{array}{l}-0.184 \\
(1.042)\end{array}$ & $\begin{array}{l}-0.575 \\
(1.083)\end{array}$ & $\begin{array}{l}-0.367 \\
(0.347)\end{array}$ \\
\hline Birth Order & $\begin{array}{l}2.585 \\
1.796\end{array}$ & $\begin{array}{l}-0.045 \\
(0.153)\end{array}$ & $\begin{array}{l}-0.078 \\
(0.225)\end{array}$ & $\begin{array}{l}-0.335 \\
(0.395)\end{array}$ & $\begin{array}{c}0.140 \\
(0.475)\end{array}$ & $\begin{array}{l}-0.112 \\
(0.107)\end{array}$ \\
\hline $\begin{array}{l}\text { Sibling Spacing } \\
\text { (Years) }\end{array}$ & $\begin{array}{c}4.912 \\
34.732\end{array}$ & $\begin{array}{l}-11.072 \\
(8.557)\end{array}$ & $\begin{array}{l}-0.794 \\
(0.494)\end{array}$ & $\begin{array}{c}0.238 \\
(1.129)\end{array}$ & $\begin{array}{c}-0.751 * * \\
(0.382)\end{array}$ & $\begin{array}{c}1.699 \\
(4.083)\end{array}$ \\
\hline $\begin{array}{l}\text { No. of Siblings FE } \\
\text { Family Land FE } \\
\text { District FE }\end{array}$ & $\begin{array}{l}- \\
- \\
-\end{array}$ & $\begin{array}{l}\mathrm{N} \\
\mathrm{Y} \\
\mathrm{Y}\end{array}$ & $\begin{array}{l}\mathrm{N} \\
\mathrm{Y} \\
\mathrm{Y}\end{array}$ & $\begin{array}{l}\mathrm{N} \\
\mathrm{Y} \\
\mathrm{Y}\end{array}$ & $\begin{array}{l}\mathrm{N} \\
\mathrm{Y} \\
\mathrm{Y}\end{array}$ & $\begin{array}{l}\mathrm{Y} \\
\mathrm{Y} \\
\mathrm{Y}\end{array}$ \\
\hline $\mathrm{N}$ & 4809 & 729 & 811 & 777 & 726 & 4809 \\
\hline
\end{tabular}

Notes:

This table presents summary statistics (mean and standard deviation) in Column 1 and assesses the conditional independence assumption of the instrument in $\mathrm{Col} 2-6$, by seeing if it is independent of a number of characteristics of the household head and the head's parents. The sample is restricted to Hindu male household heads whose parents owned land in the 1999 ARIS-REDS's survey. The data is at the household head level. †Columns 2-6 report the coefficient estimate on the instrument, Predicted Share $=1 /(1+$ Brothers $)$, from a reduced form regression of the dependent variable on the instrument. Columns 2-5 assesses balance for household heads with varying numbers of siblings, while Column 6 includes all household heads. 'Father in agriculture' is coded as 1 if the primary occupation of the head's father is agriculture. 'Dowry received' reports the natural logarithm of the value of dowry payments given to the head or his parents at the time of marriage. 'Age when Headship Assumed' reports the age at which the respondent assumed headship of the household. 'Birth Order' is an integer value that is rising in parity (1 if eldest) and 'Sibling Spacing' computes the average interval between sibling births in number years. All specifications include district fixed effects ( 99 dummies), fixed effects for family landholdings (0-80+ acres, 5 acre intervals, 15 dummies) and the number of siblings (14 dummies). The excluded group are heads who are only children, from West Godavari district in Andhra Pradesh with family landholdings between 0-5 acres. Brothers are defined as male siblings who grew up to at least the age of 10 . Results are robust to alternative definitions and using ever born siblings. Robust standard errors are given in parentheses, asterisks denote significance: $* \mathrm{p}<0.10, * * \mathrm{p}<0.05, * * *$ $\mathrm{p}<0.01$. Data Source: ARIS-REDS Dataset. 
TABLE 9: THE FIRST STAGE AND REDUCED FORM EFFECTS IN STATES WITH MATRILINEAL INHERITANCE RULES (2SLS ESTIMATES)

\begin{tabular}{|c|c|c|c|c|c|c|c|c|}
\hline \multirow[b]{2}{*}{ Dependent Variable } & \multicolumn{4}{|c|}{ Patrilineal vs. Matrilineal Areas } & \multicolumn{4}{|c|}{ Landed vs. Landless Parents } \\
\hline & $\begin{array}{c}\text { Education } \\
\text { (Years) } \\
(1)\end{array}$ & $\begin{array}{c}\text { Land Owned } \\
\text { (Acres) } \\
\text { (2) }\end{array}$ & $\begin{array}{c}\text { Non-Ag } \\
\text { Occupation } \\
\text { (Binary) } \\
\text { (3) }\end{array}$ & $\begin{array}{c}\mathrm{HH} \\
\text { Consumption } \\
\text { Log (Rs.) } \\
\text { (4) }\end{array}$ & $\begin{array}{c}\text { Education } \\
\text { (Years) } \\
(5)\end{array}$ & $\begin{array}{c}\text { Net Dowry } \\
\text { (Binary) } \\
(6)\end{array}$ & $\begin{array}{c}\text { Non-Ag } \\
\text { Occupation } \\
\text { (Binary) } \\
(7)\end{array}$ & $\begin{array}{c}\mathrm{HH} \\
\text { Consumption } \\
\text { Log (Rs.) } \\
(8)\end{array}$ \\
\hline Predicted Share & $\begin{array}{c}1.158 * * * \\
(0.224)\end{array}$ & $\begin{array}{l}1.554 * * * \\
(0.259)\end{array}$ & $\begin{array}{c}-0.073 * * * \\
(0.023)\end{array}$ & $\begin{array}{c}0.110 * * * \\
(0.030)\end{array}$ & $\begin{array}{c}1.529 * * * \\
(0.361)\end{array}$ & $\begin{array}{c}-0.098 * * * \\
(0.028)\end{array}$ & $\begin{array}{c}-0.107 * * * \\
(0.033)\end{array}$ & $\begin{array}{c}0.198 * * * \\
(0.040)\end{array}$ \\
\hline $\begin{array}{l}\text { Dummy for Restricted Sample } \\
\text { (Matrilineal/Landless Parents) }\end{array}$ & $\begin{array}{c}3.134 \\
(1.945)\end{array}$ & $\begin{array}{c}0.772 \\
(0.607)\end{array}$ & $\begin{array}{c}-0.711 * * * \\
(0.257)\end{array}$ & $\begin{array}{c}-0.741 * * \\
(0.308)\end{array}$ & $\begin{array}{c}-1.038 * * * \\
(0.339)\end{array}$ & $\begin{array}{c}0.033 \\
(0.028)\end{array}$ & $\begin{array}{c}0.103 * * * \\
(0.031)\end{array}$ & $\begin{array}{l}-0.024 \\
(0.037)\end{array}$ \\
\hline Predicted Share*Dummy & $\begin{array}{c}0.399 \\
(0.545)\end{array}$ & $\begin{array}{c}-1.245^{* * *} \\
(0.377)\end{array}$ & $\begin{array}{l}0.132 * * \\
(0.065)\end{array}$ & $\begin{array}{c}-0.153 * * \\
(0.078)\end{array}$ & $\begin{array}{l}-0.621 \\
(0.579)\end{array}$ & $\begin{array}{l}-0.017 \\
(0.038)\end{array}$ & $\begin{array}{c}0.137 * * * \\
(0.053)\end{array}$ & $\begin{array}{c}-0.199 * * * \\
(0.063)\end{array}$ \\
\hline Father's Occupation FE & $\mathrm{Y}$ & $\mathrm{Y}$ & $\mathrm{Y}$ & $\mathrm{Y}$ & $\mathrm{N}$ & $\mathrm{N}$ & $\mathrm{N}$ & $\mathrm{N}$ \\
\hline Age \& Education FE & $\mathrm{Y}$ & $\mathrm{Y}$ & $\mathrm{Y}$ & $\mathrm{Y}$ & $\mathrm{N}$ & $\mathrm{N}$ & $\mathrm{N}$ & $\mathrm{N}$ \\
\hline District FE & $\mathrm{Y}$ & $\mathrm{Y}$ & $\mathrm{Y}$ & $\mathrm{Y}$ & $\mathrm{Y}$ & $\mathrm{Y}$ & $\mathrm{Y}$ & $\mathrm{Y}$ \\
\hline No. of Siblings FE & $\mathrm{Y}$ & $\mathrm{Y}$ & $\mathrm{Y}$ & $\mathrm{Y}$ & $\mathrm{Y}$ & $\mathrm{Y}$ & $\mathrm{Y}$ & $\mathrm{Y}$ \\
\hline Family Land FE & $\mathrm{N}$ & $\mathrm{N}$ & $\mathrm{N}$ & $\mathrm{N}$ & $\mathrm{Y}$ & $\mathrm{Y}$ & $\mathrm{Y}$ & $\mathrm{Y}$ \\
\hline $\begin{array}{l}\text { Can Reject Null Hypothesis in } \\
\text { Restricted Sample? }\end{array}$ & $\mathrm{Y}$ & $\mathrm{Y}$ & $\mathrm{N}$ & $\mathrm{N}$ & $\mathrm{N}$ & $\mathrm{Y}$ & $\mathrm{N}$ & $\mathrm{N}$ \\
\hline Depvar Mean & 5.077 & 1.652 & 0.430 & 13.413 & 5.540 & 0.703 & 0.353 & 10.377 \\
\hline First Stage F-statistic & 25.08 & 33.667 & - & - & 17.974 & 12.176 & - & - \\
\hline $\mathrm{N}$ & 11181 & 11181 & 11181 & 11181 & 6124 & 6124 & 6124 & 6124 \\
\hline Data Source & & n Human Devel & ment Survey & $004-2005$ & & ARIS-REI & 1999 Wave & \\
\hline
\end{tabular}

Notes:

This table tests whether the first stage and reduced form vary differentially in states with matrilineal and patrilineal land inheritance rules and between household heads whose parents were landless and landed towards supporting the exclusion restriction assumption. In columns 1-4 the data is limited to Hindu male household heads in the 2004-2005 wave of the Indian Human Development Survey, who reside in rural areas. In columns 5-8 the sample is limited to Hindu male household heads whose parents were either landed or landless in the 1999 ARIS-REDS's survey. For columns 1-4 the' restricted sample' is the subset of households Kerala, Assam, Arunachal Pradesh, Meghalaya, Manipur, Mizoram, Tripura, Nagaland or Sikkim. These are areas reported as having Matrilineal or Bilateral Inheritance laws in Agarwal (2004). For columns 5-8 it is the subset of households whose parents were landless. First stage F-statistics and sample sizes are reported separately for the full and restricted samples. The 'Dummy for Restricted Sample' corresponds to a dummy coded as 1 if the observation is from the restricted sample and 0 otherwise. Each column reports the coefficients from the reduced form regression of the dependent variable on the instrument, Predicted Share $=(1 / 1+$ Brothers $)$, the 'Dummy for Restricted Sample' and their interaction. The dependent variable in Column 1 and 5 are the years of education of the head of the household. The dependent variable in Column 2 is current land owned (acres). The dependent variable in Column 3 and Column 7 is a dummy variable if the head has a non agricultural occupation. Non-Ag occupation is defined by the primary status reported by the respondent in the survey. The variable is coded as 0 if this is self-cultivation or agricultural labor and 1 otherwise. The dependent variable column 4 and column 8 is the natural logarithm of yearly household consumption. This includes food and non-food items, and values home production at village-specific market prices. The dependent variable in column 6 is a dummy variable for whether net dowry receipts are above or below the median. The former is calculated as the net sum of all dowry payments and receipts for the parents, which are reported for each sibling of the head of the household. $37 \%$ of the sample do not report paying or receiving dowry. All specifications include district fixed effects ( 99 dummies) and the number of siblings (14 dummies). Specifications 1-4 include fixed effects for head's education ( 0 - 15 years, 1 year intervals, 14 dummies), age of the household head (20-100, 5 year intervals, 15 dummies), father's occupation ( 89 dummies), and father's education (0-15, years, 1 year intervals, 14 dummies). Parent's landholdings are not reported in the IHDS data. Specifications 5-8 include fixed effects for family landholdings ( $0-80+$ acres, 5 acre intervals, 15 dummies). The F-stat reported is the partial F-statistic for the instrument(s) ( CraggDonald Wald F-statistic). Robust standard errors are given in parentheses, asterisks denote significance: ${ }^{*} \mathrm{p}<0.10,{ }^{* *} \mathrm{p}<0.05,{ }^{* * *} \mathrm{p}<0.01$. Data Sources: ARIS-REDS Dataset and Indian Human Development Survey. 


\section{Appendix A1: Variable Definitions}

Birth Order: This variable is constructed using the date of birth of all siblings of the head of the household and their own date of birth. The variable is ordered by year of birth and any siblings born in the same year as assigned the same birth order.

Changes in Landholdings : This variable is constructed for all siblings of the household head including himself. It is the difference between the reported amount of current land owned by the sibling and the land inherited.

Hired Agricultural Labor : This variable aggregates self-reported information on the number of man days and the wage rate paid to for agricultural labor by task. The tasks include preparatory tillage, sowing \& transplanting, manuring \& fertilizer, weeding \& interculture, irrigation, harvesting, threshing \& winnowing and 'other operations'. The total value of hired labor for each of these tasks is then summed.

Household Consumption : This variable is an aggregate of yearly expenditure on cereals (rice, wheat, maize, bajra, jowar, ragi and other cereals), pulses (tur, gram, urd, moong and other pulses) and values home production of these crops at village specific market prices.Other food items include gur/khandsari, edible oils, spices, milk, milk products, eggs, meat, fish, fruits, vegetables, bread, biscuits, confectionaery, processed food, beverages, cooked meals as wages and any other items. Any home production of these items is also valued at village-specific market prices.

This measure of consumption also includes yearly expenditure on durables including radios, transistors, fans, torch, lantern, petromax, metal utensils, water boilers, buckets, korosen stoves, bicycles, tricyles, motor cycle/scooter, car/jeep/van, sewing machines, wooden 
furniture, cots, wooden boxes, Almirahs, steel trunk/boxes, steel furniture, watches, clock/time piece, camera, television, VCR, cassette recorder, washing machines, pressure cookers, mixed/grinder, electric iron, geysers, refrigerators, cassette players and walkmans.

Expenditure on clothing was elicited separately and includes expenditure on readymade garments, dhoties, sarees, cloth for garments, shawls/pullovers, hosiery, footwear, tailoring charges. Expenditure on fuel - and any home production using for consumption - was also elicited separately and is include in the measure of consumption. This includes firewood, kerosene, charcoal, soft coke, gas, electricity and other fuels.

The final set of expenditure categories include toiletry and cosmetics, bedding charges, towels/linen, pan/beedis/cigarettes, intoxicants, newspapers/periodicals, medical expenses for all household members, education expenses, entertainment expenses, expenses in hotels/restaurants, house rent paid, repairs to house rented-in, repairs to consumer durables, payments to domestic servants, payments to barber/laundry/priest/sweeper, travel expenses other regular expenses, expenditure on marriage ceremonies (including gifts), expenditure on other social ceremonies and expenditure on religious ceremonies.

Inherited Land : This variable is directly asked from respondents, distinct from land currently owned, and is measured in acres. The question asked is '[What is the amount of ] land inherited prior to recent period'.

Family Land: This variable is directly asked from respondents and is measured in acres. The question asked is '[What is the amount of] land owned by head's parents?'.

Land Improvement: This variable sums the costs of hired labor, the imputed value of family labor and any material costs - valued at market rates - incurred in improving the 
quality of land through terracing, bunding, leveling, fencing and reclamation in the last 10 years.

Land Increase : This variable is constructed for all siblings of the household head including himself. It is coded as ' 1 ' if the respondent's current landholdings are greater than their inherited landholdings and '0' otherwise.

Net Dowry : The household head is asked the value of dowry payments paid and received by his parents for each of his siblings. Net dowry is the difference between the value of all payments received minus all payments paid.

Non-agricultural Occupation: The question asked in the survey used to define this variable is the household head's response to their 'Primary Activity Status'. The options for this question include 1. self-employed farming, 2. self employed non-farming, 3. salaried, 4.agricultural wages, 5.non-agricultural wages, 6. agricultural family worker, 7.non-agricultural family worker, 8.pensioner, 9. other. 'Non-agricultural occupation' was coded as ' 0 ' if the head responded with 1,4,6 or 7 and ' 1 ' otherwise.

Predicted Share : This instrument is constructed using the total number of brothers reported by a respondent who reached the age of 10 . This data is contained in a section enumerating all siblings of the head of the household

Rural to Urban Migration : The household head is asked where each sibling and child 'lives now', where the options are: 1. same village, 2. town in same district, 3. village in same district, 4 . town in other district of same state, 5 . village in other district of same state, 6. town of other state, 7 . village of other state or 8 . village/town of other country. The variable is coded as ' 1 ' if head responded with 2,4,6 or 8 , and ' 0 ' otherwise. 
Total Man Days of Agricultural Labor : This variable aggregates self-reported information on the number of days in the past year the household head worked in agricultural labor by aggregating the number of man days reported for preparatory tillage, sowing \& transplanting, manuring \& fertilizer, weeding \& interculture, irrigation, harvesting, threshing \& winnowing and 'other operations'.

Total Man Days of Non-Agricultural Labor : This variable aggregates self-reported information on the number of days in the past year the household head worked in a selfemployment activity, as a salary earner, and as a wage earner.

Took out Loan : This variable is coded as ' 1 ' if the respondent reported taking out a loan in the last five years. The loans could be taken out for any purpose including agricultural investment, investment in self-employment enterprises, social ceremonies, purchasing of consumer durables, education of children or 'other'.

Total Value of Loans: This variable sums the total amount repaid and the total amount outstanding for loans taken out in the last five years. This includes both cash loans and the rupees value of in-kind loans. 


\section{APPENDIX A2: UNDERSTANDING OF INHERITANCE RULES FROM GUJARAT DATA}

\begin{tabular}{lcc}
\hline \hline \multicolumn{2}{l}{ Table A2.1 Understanding of Inheritance Rule } & \\
& Freq. & Percent \\
\hline Equal Shares to all sibs & 152 & 14.66 \\
Equal Shares to brothers & 852 & 82.16 \\
Oldest Brother gets more & 2 & 0.19 \\
No Standard Rule & 19 & 1.83 \\
888 & 4 & 0.39 \\
999 & 8 & 0.77 \\
Total & 1,037 & 100 \\
\hline \hline
\end{tabular}

Table A2.2 Do Some Brothers Inherit Better Land than Others? Freq. Percent

\begin{tabular}{lcc}
\hline & 302 & 29.12 \\
Yes & 733 & 70.68 \\
No & 1 & 0.1 \\
888 & 1 & 0.1 \\
999 & 1,037 & 100 \\
Total & \\
\hline \hline
\end{tabular}

Table A2.3 If one brother has more education or a better job, will he inherit less land?

\begin{tabular}{lcc} 
& Freq. & Percent \\
\hline Yes & 70 & \\
No & 965 & 6.75 \\
888 & 1 & 93.06 \\
999 & 1 & 0.1 \\
Total & 1,037 & 0.1 \\
\hline \hline
\end{tabular}

Notes:

These tables present summary statistics on perceptions of land inheritance rules and adherence to them. The data was collected by the author and is from a random sample of 1,037 respondents enganged in agriculture in Gujarat, India. Data Source: Collected by Author 
APPENDIX A3: DETAILS OF NON-AGRICULTURAL OCCUPATIONS

\begin{tabular}{lcc}
\hline \hline \multirow{2}{*}{ Table A3.1 Distribution of Non-Agricultural Occupations } \\
& Freq. & Percent \\
\hline & 259 & 18.05 \\
Non-farm business & 458 & 31.92 \\
Salaried position & 315 & 21.95 \\
Non-agricultural wage work & 403 & 28.08 \\
Other & 1435 & 100.00 \\
Total & & \\
\hline \hline & & \\
& & \\
Table A3.2: Details of Salaried Work & Freq. & Percent \\
\hline & 101 & \\
Teachers & 79 & 17.59 \\
Service Workers (guides, undertakers & 60 & 13.36 \\
and embalmers, peons, helper, priest) & 209 & 46.55 \\
Clerical and related workers & 449 & 31.29 \\
Other &
\end{tabular}

\begin{tabular}{lcc}
\hline \hline Table A3.3: Details of Non-Farm Businesses \\
& Freq. & Percent \\
\hline & 45 & 17.44 \\
General Merchant & 14 & 5.43 \\
Tea Shop, Restaurant, Hotel & 13 & 5.04 \\
Tailoring & 12 & 4.65 \\
Artisan & 11 & 4.26 \\
Commission Agent & 186 & 72.09 \\
Other & 258 & 100.00 \\
Total & & \\
\hline \hline
\end{tabular}

Notes:

These tables present summary statistics on the breakdown of non-agricultural occupations. The occupational classifications are based on what users report as their primary activity status in the data. The sample is restricted to all children of Hindu male household heads whose parents owned land in the 1999 ARIS-REDS's survey. Data Source: ARIS-REDS Dataset. 


\begin{tabular}{|c|c|c|c|}
\hline & Oc & Occupational Wage Gaps by Farmer Landholdings & $\begin{array}{l}\text { andholdings } \\
\text { (3) }\end{array}$ \\
\hline Comparison Group & All Farmers & $<=3$ acres & $>3$ acres \\
\hline \multicolumn{4}{|c|}{ A. Primary Occupation: Non-Farm Business } \\
\hline Wage Gap & $\begin{array}{l}-1.219 \\
(1.603)\end{array}$ & $\begin{array}{c}18.885^{* * * *} \\
(1.827)\end{array}$ & $\begin{array}{c}-10.669 * * * \\
(1.834)\end{array}$ \\
\hline $\mathrm{N}$ & 30707 & 13621 & 22266 \\
\hline \multicolumn{4}{|l|}{ B. Primary Occupation: Salaried Job } \\
\hline Wage Gap & $\begin{array}{c}21.610 * * * \\
(2.051)\end{array}$ & $\begin{array}{c}37.265^{* * * *} \\
(2.347)\end{array}$ & $\begin{array}{l}11.290 * * * \\
(2.258)\end{array}$ \\
\hline $\mathrm{N}$ & 31637 & 14551 & 23196 \\
\hline \multicolumn{4}{|c|}{ C. Primary Occupation: Non-Agricultural Labor } \\
\hline Wage Gap & $\begin{array}{c}-15.062 * * * \\
(1.113)\end{array}$ & $\begin{array}{c}4.695 * * * \\
(1.236)\end{array}$ & $\begin{array}{c}-26.601 * * * \\
(1.398)\end{array}$ \\
\hline $\mathrm{N}$ & 35019 & 17933 & 26578 \\
\hline Daily Wage for Comparison Farmers & 81.902 & 50.933 & 97.171 \\
\hline Sex FE & $\mathrm{Y}$ & $\mathrm{Y}$ & $\mathrm{Y}$ \\
\hline Age FE & $\mathrm{Y}$ & Y & Y \\
\hline Education FE & $\mathrm{Y}$ & $\mathrm{Y}$ & $\mathrm{Y}$ \\
\hline District FE & $\mathrm{Y}$ & $\mathrm{Y}$ & $\mathrm{Y}$ \\
\hline
\end{tabular}

Notes:

This table computes differences in the average daily wage within districts by occupation in rural India. The sample is restricted to all individuals in rural India in the Indian Human Development Survey. Column 1 in Panel A reports the estimated OLS coefficient from a regression of the daily wage on a dummy variable coded as 1 if the main source of income is business and 0 if it is farming. Column 2 reports the same coefficient but restricting the comparison group to farmers with less than or equal to 3 acres of land. Column 3 restricts the comparison group to farmers with more than 3 acres of land. Panel B does similary where the main ocupation is instead a salaried job, and Panel C considers Non-agricultural wage work. All specifications include district fixed effects, non-parametric controls for sex, age (15 dummies, 0-80, 5 year intervals) and years of education (15 dummies, 0-15 years, 1 year intervals). Primary Source of Income defined as source of income with highest proportion relative to total income for an indvidual. A 'farmer' is defined as an individual whose highest proportion of income is from own agricultural cultivation or agricultural labor. The daily wage for farming is calculated as total farm profit divided by the number of days spent in agricultural labor, or the agricultural wage income in the case of agricultural labor. Data Source: Indian Human Development Survey. 


\section{APPENDIX A5: DEMOGRAPHIC CHARACTERISTICS}

\begin{tabular}{ccc}
\hline \hline \multirow{3}{*}{$\begin{array}{c}\text { Table A5.1: Distribution of Number of Siblings } \\
\text { Siblings }\end{array}$} & $\begin{array}{c}\text { Frequency } \\
(1)\end{array}$ & $\begin{array}{c}\text { Percent } \\
(3)\end{array}$ \\
\hline & & \\
0 & 274 & 5.7 \\
1 & 473 & 9.84 \\
2 & 729 & 15.16 \\
3 & 811 & 16.86 \\
4 & 777 & 16.16 \\
5 & 726 & 15.1 \\
6 & 506 & 10.52 \\
7 & 265 & 5.51 \\
8 & 142 & 2.95 \\
9 & 64 & 1.33 \\
10 & 32 & 0.67 \\
11 & 5 & 0.1 \\
12 & 3 & 0.06 \\
14 & 2 & 0.04 \\
Total & 4809 & 100 \\
& & \\
Mean & 3.77 & - \\
Median & 4.00 & - \\
\hline \hline
\end{tabular}

Table A5.2: Distribution of Number of Brothers Brothers Frequency Percent
(1)
(2)
(3)

\begin{tabular}{ccc}
\hline & 782 & 16.26 \\
0 & 1,288 & 26.78 \\
1 & 1,270 & 26.41 \\
2 & 795 & 16.53 \\
3 & 421 & 8.75 \\
4 & 181 & 3.76 \\
5 & 56 & 1.16 \\
6 & 10 & 0.21 \\
7 & 6 & 0.12 \\
8 & 4,809 & 100 \\
Total & & \\
& 1.92 & - \\
Mean & 2.00 & - \\
Median & & \\
\hline \hline
\end{tabular}

\begin{tabular}{ccc}
\hline \multicolumn{3}{c}{ Table A5.3: Distribution of Birth Order } \\
$\begin{array}{c}\text { Birth Order } \\
(1)\end{array}$ & $\begin{array}{c}\text { Frequency } \\
(2)\end{array}$ & $\begin{array}{c}\text { Percent } \\
(3)\end{array}$ \\
\hline & & \\
1 & 1,814 & 37.72 \\
2 & 1,035 & 21.52 \\
3 & 715 & 14.87 \\
4 & 544 & 11.31 \\
5 & 304 & 6.32 \\
6 & 211 & 4.39 \\
7 & 99 & 2.06 \\
8 & 52 & 1.08 \\
9 & 21 & 0.44 \\
10 & 10 & 0.21 \\
11 & 4 & 0.08 \\
Total & 4,809 & 100 \\
\hline \hline
\end{tabular}

Notes:

These tables report summary statistics on the distribution of siblings, brothers and birth order. Siblings born in the same year were assigned the same birth order since it is not possible to distinguish between twins and those born in the same calendar year. The sample is restricted to all children of Hindu male household heads whose parents owned land in the 1999 ARIS-REDS's survey. Data Source: ARIS-REDS Dataset. 


\section{APPENDIX A6: DETAIL ON BORROWING}

\begin{tabular}{lrr}
\hline \hline Table A6.1 : Purpose of Loan & & \\
& Freq. & Percent \\
\hline Agricultural Investment & 332 & 27.35 \\
Non-Agricultural Investment & 384 & 31.63 \\
Self Employment & 67 & 5.52 \\
Repayment of Earlier Loans & 7 & 0.58 \\
Social Ceremonies & 78 & 6.43 \\
Purchasing Consumer Durables & 42 & 3.46 \\
Education of Children & 10 & 0.82 \\
Other & 294 & 24.22 \\
Total & 1214 & 100.01 \\
\hline \hline \multicolumn{3}{c}{} \\
\hline \hline \multirow{2}{*}{ Table A6.2 : Collateral Required for Loan? } \\
\multicolumn{3}{c}{ Freq. } \\
\hline \multirow{3}{*}{ Percent } \\
Yes & 285 & 23.48 \\
No & 929 & 76.52 \\
Total & 1,214 & 100 \\
\hline \hline
\end{tabular}

Table A6.3 : Type of Collateral

Freq.

Percent

Land $\quad 236 \quad 83.1$

Gold and Jewellery $\quad 22 \quad 7.75$

Agricultural Asset $\quad 1 \quad 0.35$

Consumer Durable $\quad 1 \quad 0.35$

\begin{tabular}{lll} 
Others & 24 & 8.45 \\
\hline
\end{tabular}

Total $284 \quad 100$

Notes:

These figures correspond to all loans taken out in the last 5 years by male Hindu household heads who parents owned land in the 1999 ARIS-REDS survey. Data source: ARIS-REDS Dataset. 


\section{APPENDIX B1: EFFECTS OF EXPECTED INHERITANCE OF LAND ON OCCUPATIONAL CHOICE, CONSUMPTION AND EDUCATION}

\begin{tabular}{|c|c|c|c|c|c|c|}
\hline \multirow[t]{2}{*}{ Dependent Variable } & \multicolumn{2}{|c|}{$\begin{array}{c}\text { Non-Ag Occupation } \\
\text { Binary Variable }\end{array}$} & \multicolumn{2}{|c|}{$\begin{array}{c}\text { Household Consumption } \\
\text { Log(Rs.) }\end{array}$} & \multicolumn{2}{|c|}{$\begin{array}{l}\text { Education } \\
\text { (Years) }\end{array}$} \\
\hline & $\begin{array}{c}\text { OLS } \\
(1) \\
\end{array}$ & $\begin{array}{c}2 \text { SLS } \\
(2)\end{array}$ & $\begin{array}{c}\text { OLS } \\
\text { (3) } \\
\end{array}$ & $\begin{array}{c}2 \text { SLS } \\
(4) \\
\end{array}$ & $\begin{array}{l}\text { OLS } \\
(5) \\
\end{array}$ & $\begin{array}{c}2 \text { SLS } \\
(6)\end{array}$ \\
\hline $\begin{array}{l}\text { Inherited Land } \\
\text { (Acres) }\end{array}$ & $\begin{array}{c}-0.253^{* *} \\
(0.125)\end{array}$ & $\begin{array}{l}-0.140^{*} \\
(0.081)\end{array}$ & $\begin{array}{c}0.056 \\
(0.121)\end{array}$ & $\begin{array}{c}0.031 \\
(0.061)\end{array}$ & $\begin{array}{l}-0.000 \\
(1.264)\end{array}$ & $\begin{array}{l}-0.000 \\
(0.650)\end{array}$ \\
\hline No. of Siblings FE & $\mathrm{Y}$ & $\mathrm{Y}$ & $\mathrm{Y}$ & $\mathrm{Y}$ & $\mathrm{Y}$ & $\mathrm{Y}$ \\
\hline Family Land FE & $\mathrm{Y}$ & $\mathrm{Y}$ & $\mathrm{Y}$ & Y & $\mathrm{Y}$ & $\mathrm{Y}$ \\
\hline District FE & $\mathrm{Y}$ & $\mathrm{Y}$ & $\mathrm{Y}$ & $\mathrm{Y}$ & $\mathrm{Y}$ & $\mathrm{Y}$ \\
\hline Mean of Dep. Var. & 0.33 & 0.33 & 10.288 & 10.288 & 6.688 & 6.688 \\
\hline First Stage F-statistic & - & 4.898 & - & 4.898 & - & 4.898 \\
\hline $\mathrm{N}$ & 898 & 898 & 898 & 898 & 898 & 898 \\
\hline
\end{tabular}

Notes:

This table reports estimates of the long-term effect of inherited land occupational choice, household consumption and education for the subsample of heads whose father is still alive. The sample in columns 1,2,5 and 6 is restricted to Hindu male household heads whose parents owned land in the 1999 ARIS-REDS's survey. The data is at the household head level. The sample in column 3 and 4 are all male siblings of these household heads (including the heads) aged above 10 years. Note, this data is reported for all siblings not just siblings residing in the household at the time of the survey. Panel A includes all households, while Panel B limits the analysis to households whose family had less than 3 acres. The dependent variable in col 1 and 2 is Non-Ag occupation and is defined as the primary status reported by the respondent in the REDS survey. The variable is coded as 0 if this is self-cultivation or agricultural labor and 1 otherwise. The dependent variable in column 3 and 4 is dummy variable for whether or not the sibling migrated to an urban area in the same district or outside of it. The dependent variable col 5 and 6 is the natural logarithm of yearly household consumption. This includes food and non-food items, and values home production at village-specific market prices. All specifications include district fixed effects (99 dummies), fixed effects for family landholdings (0-80+ acres, 5 acre intervals, 15 dummies) and the number of siblings (14 dummies). The excluded group are heads who are only children from West Godavari district in Andhra Pradesh with family landholdings between 0-5 acres. The instrument specfication used is Predicted Share $=1 /(1+$ Brothers $)$. The F-stat reported is the partial F-statistic for the instrument(s) ( Cragg-Donald Wald F-statistic). Robust standard errors are given in parentheses, asterisks denote significance: $* \mathrm{p}<0.10, * * \mathrm{p}<0.05, * * * \mathrm{p}<0.01$. Standard errors are clustered at the family level for sibling-level regressions. Data Source: ARIS-REDS Dataset. 


\section{Appendix B2: The Effects of Birth Order on Land Own- ership (Sibling-Level Data)}

Appendix B2 reports the coefficients on the birth order dummies from the following withinfamily regression:

$$
\begin{aligned}
Y_{i j}= & \alpha_{j}+\gamma_{z} \sum_{z=1}^{6} I\left(\text { Birthorder }_{i j}=z\right)+\mu_{1} \text { Age_Dummies }_{i j} \\
& +\mu_{2} \text { Education_Dummies }_{i j}+\eta_{i j}
\end{aligned}
$$

Where $\mathrm{Y}$ is a dummy coded as 1 if current landholdings are greater than inherited landholdings and 0 otherwise, for sibling $i$ of head $j$, and $\alpha_{j}$ is a family fixed effect. Column (2) shows that latter-borns are less likely to experience an increase in their current landholdings over their inherited landholdings. In the main sample, $26 \%$ of household heads report that they experienced an increase in their landholdings over the prior two decades. Of these respondents, nearly 40\% report receiving 'gifts' of land, a category distinct to inheriting, leasing or purchasing land. While no further details are given about these gifts in the 1999 wave, in the 2006 wave of the REDS survey, $80 \%$ of land leased in is from family members. The majority of these contracts are oral rather than written, they do not involve a fee and have no specified term. Taken together, these facts support the interpretation that latterborn siblings, unbound by social obligations, 'lease' their land to first-born siblings, and are

more likely to specialize in non-agricultural occupations to the benefit of their family's future consumption. 


\section{APPENDIX B2: THE EFFECTS OF BIRTH ORDER ON LAND OWNERSHIP (SIBLING-LEVEL DATA)}

\begin{tabular}{lccc}
\hline \hline Dependent Variable & $\begin{array}{c}\text { Inherited Land } \\
\text { (Binary }) \\
(1)\end{array}$ & $\begin{array}{c}\text { Land Increase } \\
\text { (Binary) } \\
(2)\end{array}$ & $\begin{array}{c}\text { Change } \\
\text { in Landholdings } \\
\text { (Acres) } \\
(3)\end{array}$ \\
\hline 2nd Born & -0.009 & $-0.016^{*}$ & -0.052 \\
& $(0.008)$ & $(0.008)$ & $(0.051)$ \\
3rd Born & 0.007 & $-0.032^{* * *}$ & -0.083 \\
& $(0.011)$ & $(0.011)$ & $(0.069)$ \\
4th Born & 0.010 & $-0.049^{* * *}$ & $-0.269^{* * *}$ \\
& $(0.014)$ & $(0.015)$ & $(0.092)$ \\
5th Born + & -0.001 & $-0.051^{* * *}$ & $-0.321^{* * *}$ \\
& $(0.018)$ & $(0.019)$ & $(0.118)$ \\
Constant & & & $1.382^{*}$ \\
& $0.542^{* * *}$ & $0.275^{* *}$ & $(0.751)$ \\
Family FE & $(0.112)$ & $(0.123)$ & $\mathrm{Y}$ \\
Age FE & $\mathrm{Y}$ & $\mathrm{Y}$ & $\mathrm{Y}$ \\
Depvar Mean & $\mathrm{Y}$ & $\mathrm{Y}$ & 0.731 \\
N & 0.674 & 0.256 & 14773 \\
\hline \hline
\end{tabular}

Notes:

inheriting land and changes in landholdings over time. The sample is restricted to all male siblings who reached the age of 10 years prior to death. In each family, one of the brothers is a household head in the main analysis. The data is at the sibling-level. Note, this data is reported for all siblings not just siblings residing in the household at the time of the survey. The dependent variable in Col 1-3 is the total number of man days spent in agriculture during the prior season. Columns 1-5 report the coefficient on a dummy for being the 2 nd born sibling, 3rd born sibling, 4th born sibling and the 5th born or later sibling. The dependent variable in column 1 is a dummy variable coded as 1 if the sibling inherited land. The dependent variable in column 2 is a dummy coded as 1 if the sibling's current landholdings are greater than his inherited landholdings, and in column 3 it is the diference between current and inherited landholdings in acres. All specifications include family fixed effects, age fixed effects (0-100 years, 5 year intervals, 19 dummies), and education fixed effects ( $0-14$ years, 1 year intervals, 13 dummies). The excluded group are first born siblings between the ages of 0 5 with less than an year of education. Robust standard errors are given in parentheses, asterisks denote significance: ${ }^{*} \mathrm{p}<0.10,{ }^{* *} \mathrm{p}<0.05,{ }^{* *} \mathrm{p}<0.01$. Data Source: ARIS-REDS Dataset. 
APPENDIX B3: HETEROGENEOUS EFFECTS OF INHERITED LAND BY TIMING OF HEADSHIP (2SLS ESTIMATES)

\begin{tabular}{|c|c|c|c|c|c|c|c|c|}
\hline Dependent Variable & $\begin{array}{l}\text { Non-Ag } \\
\text { Occupation } \\
\text { (Binary) }\end{array}$ & $\begin{array}{c}\mathrm{HH} \\
\text { Consumption } \\
\text { Log(Rs.) }\end{array}$ & $\begin{array}{l}\text { Non-Ag } \\
\text { Occupation } \\
\text { (Binary) }\end{array}$ & $\begin{array}{c}\mathrm{HH} \\
\text { Consumption } \\
\text { Log(Rs.) }\end{array}$ & $\begin{array}{l}\text { Non-Ag } \\
\text { Occupation } \\
\text { (Binary) }\end{array}$ & $\begin{array}{c}\mathrm{HH} \\
\text { Consumption } \\
\text { Log(Rs.) }\end{array}$ & $\begin{array}{l}\text { Non-Ag } \\
\text { Occupation } \\
\text { (Binary) }\end{array}$ & $\begin{array}{c}\mathrm{HH} \\
\text { Consumption } \\
\text { Log(Rs.) }\end{array}$ \\
\hline \multirow[t]{2}{*}{ Sample } & \multicolumn{2}{|c|}{ All } & \multicolumn{2}{|c|}{ Only First Borns } & \multicolumn{2}{|c|}{ Only Latter Borns } & \multicolumn{2}{|c|}{ All } \\
\hline & $(1)$ & $(2)$ & (3) & $(4)$ & $(5)$ & $(6)$ & $(7)$ & $(8)$ \\
\hline Land & $\begin{array}{c}-0.024 * * * \\
(0.008)\end{array}$ & $\begin{array}{c}0.031 * * * \\
(0.010)\end{array}$ & $\begin{array}{c}-0.041 * * * \\
(0.012)\end{array}$ & $\begin{array}{c}0.035^{* *} \\
(0.015)\end{array}$ & $\begin{array}{l}-0.011 \\
(0.010)\end{array}$ & $\begin{array}{c}0.035 * * * \\
(0.013)\end{array}$ & $\begin{array}{l}-0.009 \\
(0.011)\end{array}$ & $\begin{array}{c}0.040 * * * \\
(0.014)\end{array}$ \\
\hline $\begin{array}{l}\text { Below Median Age } \\
\text { (BMA) }\end{array}$ & $\begin{array}{l}-0.046 \\
(0.048)\end{array}$ & $\begin{array}{l}-0.075 \\
(0.055)\end{array}$ & $\begin{array}{c}0.096 \\
(0.114)\end{array}$ & $\begin{array}{l}0.232 * \\
(0.134)\end{array}$ & $\begin{array}{l}-0.029 \\
(0.058)\end{array}$ & $\begin{array}{l}-0.102 \\
(0.070)\end{array}$ & $\begin{array}{c}0.008 \\
(0.013)\end{array}$ & $\begin{array}{l}-0.077 \\
(0.075)\end{array}$ \\
\hline Land*BMA & $\begin{array}{c}0.011 \\
(0.011)\end{array}$ & $\begin{array}{l}-0.007 \\
(0.013)\end{array}$ & $\begin{array}{l}-0.023 \\
(0.027)\end{array}$ & $\begin{array}{c}-0.072 * * \\
(0.032)\end{array}$ & $\begin{array}{c}0.007 \\
(0.013)\end{array}$ & $\begin{array}{l}-0.003 \\
(0.016)\end{array}$ & $\begin{array}{l}-0.027 \\
(0.032)\end{array}$ & $\begin{array}{l}-0.005 \\
(0.017)\end{array}$ \\
\hline Land*BMA*Firstborn & - & - & - & - & - & - & $\begin{array}{l}-0.027 \\
(0.032)\end{array}$ & $\begin{array}{l}-0.058 \\
(0.038)\end{array}$ \\
\hline No. of Siblings FE & Y & $\mathrm{Y}$ & $\mathrm{Y}$ & Y & $\mathrm{Y}$ & $\mathrm{Y}$ & $\mathrm{Y}$ & $\mathrm{Y}$ \\
\hline Family Land FE & $\mathrm{Y}$ & Y & $\mathrm{Y}$ & $\mathrm{Y}$ & $\mathrm{Y}$ & $\mathrm{Y}$ & $\mathrm{Y}$ & $\mathrm{Y}$ \\
\hline District FE & $\mathrm{Y}$ & $\mathrm{Y}$ & $\mathrm{Y}$ & $\mathrm{Y}$ & $\mathrm{Y}$ & $\mathrm{Y}$ & $\mathrm{Y}$ & $\mathrm{Y}$ \\
\hline Depvar Mean & 0.298 & 10.442 & 0.298 & 10.442 & 0.298 & 10.442 & 0.298 & 10.442 \\
\hline $\begin{array}{l}\text { First Stage F-Stat } \\
\mathrm{N}\end{array}$ & 44.733 & 44.733 & 9.182 & 9.182 & 19.944 & 19.944 & 3.752 & 3.752 \\
\hline
\end{tabular}

Notes:

This table tests whether the timing of becoming a household head influences occupational choice and household consumption. All coefficients reported are 2SLS estimates. The sample is restricted to first born Hindu male household heads whose parents owned land in the 1999 ARISREDS's survey. The data is at the household head level. The sample in co1 1-2 includes all respondents, in col 3-4 the sample includes only first born respondents, in col 5-6 it includes only latter borns, and in col 7-8 it includes all respondents. Columns 1-6 reports the 2SLS coefficients on inherited land, a dummy variable (Below Median Age) coded as 1 if the respondent became the head of the household at an age that was below the median for the sample (32 years) and their interaction. The two endogenous variables are instrumented with two instruments : Predicted Share $=(1 / 1+$ Brothers $)$ and the interaction between Predicted Share and the dummy for Below Median Age. In columns 7-8 the specification includes two additional endogenous variables: the interaction between inherited land and a dummy for first born and the triple interaction between inherited land, a dummy for below median age and a dummy for firstborn. The latter two variables are instrumented with the interaction predicted share and first born and the triple interaction between predicted share, first born and a dummy for below median age. The specification also includes controls for first born and its interact with below median age but these are not reported. The dependent variable in columns 1,3,5 and 7 is Non-Ag occupation, and is defined as the primary status reported by the respondent in the REDS survey. The variable is coded as 0 if this is selfcultivation or agricultural labor and 1 otherwise. The dependent variable in columns 2,4,6 and 8 is the natural logarithm of yearly household consumption. This includes food and non-food items, and values home production at village-specific market prices. All specifications include district fixed effects (99 dummies), fixed effects for family landholdings ( $0-80+$ acres, 5 acre intervals, 15 dummies) and the number of siblings (14 dummies). The excluded group are heads who are only children, from West Godavari district in Andhra Pradesh with family landholdings between 0-5 acres. The F-stat reported is the partial F-statistic for the instrument(s) ( Cragg-Donald Wald F-statistic). Robust standard errors are given in parentheses, asterisks denote significance: $* \mathrm{p}<0.10, * * \mathrm{p}<0.05, * * * \mathrm{p}<0.01$. Data Source: ARIS-REDS Dataset. 


\section{APPENDIX B4: HETEROGENEOUS EFFECTS OF INHERITED LAND BY CROPPING PATTERNS (2SLS ESTIMATES)}

\begin{tabular}{lcc}
\hline \hline Dependent Variable & $\begin{array}{c}\text { Non-Ag Occupation } \\
\text { (Binary) } \\
(1)\end{array}$ & $\begin{array}{c}\text { HH Consumption } \\
\text { Log(Rs. }) \\
(2)\end{array}$ \\
\hline Land & -0.007 & $0.015^{* *}$ \\
& $(0.006)$ & $(0.007)$ \\
Paddy & $-0.144^{* * *}$ & -0.018 \\
& $(0.051)$ & $(0.059)$ \\
Land*Paddy & $-0.022^{*}$ & $0.030^{*}$ \\
& $(0.013)$ & $(0.015)$ \\
No. of Siblings FE & $\mathrm{Y}$ & $\mathrm{Y}$ \\
Family Land FE & $\mathrm{Y}$ & $\mathrm{Y}$ \\
District FE & $\mathrm{Y}$ & $\mathrm{Y}$ \\
Depvar Mean & 0.298 & 10.442 \\
First Stage F-Stat & 14.396 & 14.396 \\
$\mathrm{~N}$ & 4809 & 4809 \\
\hline \hline
\end{tabular}

Notes:

This table tests whether the types of crops grown leads to differential impacts of inherited land on occupational choice and household consumption. All coefficients reported are 2SLS estimates. The sample is restricted to first-born Hindu male household heads whose parents owned land in the 1999 ARIS-REDS's survey. The data is at the household head level. Each column reports the 2SLS coefficients on inherited land, a dummy variable (Paddy) coded as 1 if the respondent's major kharif crop is rice/paddy (i.e. greatest share of land sown) and their interaction. The two endogenous variables are instrumented with two instruments: Predicted Share $=(1 / 1+$ Brothers $)$ and the interaction between Predicted Share and Paddy. The dependent variable in Column 1, Non-Ag occupation, is defined by the primary status reported by the respondent in the REDS survey. The variable is coded as 0 if this is self-cultivation or agricultural labor and 1 otherwise. The dependent variable Column 2 is the natural logarithm of yearly household consumption. This includes food and non-food items, and values home production at village-specific market prices. All specifications include district fixed effects (99 dummies), fixed effects for family landholdings (0-80+ acres, 5 acre intervals, 15 dummies) and the number of siblings (14 dummies). The excluded group are heads who are only children, from West Godavari district in Andhra Pradesh with family landholdings between 0-5 acres. The F-stat reported is the partial F-statistic for the instrument(s) (Cragg-Donald Wald F-statistic). Robust standard errors are given in parentheses, asterisks denote significance: ${ }^{*} \mathrm{p}<0.10,{ }^{* *} \mathrm{p}<0.05,{ }^{* * *} \mathrm{p}<0.01$. Data Source: ARIS-REDS Dataset. 


\section{APPENDIX B5 : THE EFFECT OF INHERITED LAND ON NON-FARM BUSINESS OWNERSHIP, SALARIED WORK AND NON-AGRICULTURAL WAGE WORK}

\begin{tabular}{|c|c|c|c|c|c|c|}
\hline \multirow[t]{2}{*}{$\overline{\overline{\text { Dependent Variable }}}$} & \multicolumn{2}{|c|}{$\begin{array}{c}\text { Non-Farm Business } \\
\text { Binary Variable }\end{array}$} & \multicolumn{2}{|c|}{$\begin{array}{c}\text { Salaried Job } \\
\text { Binary Variable }\end{array}$} & \multicolumn{2}{|c|}{$\begin{array}{c}\text { Non-Agricultural Wage Work } \\
\text { Log(Rs.) }\end{array}$} \\
\hline & $\begin{array}{l}\text { OLS } \\
(1)\end{array}$ & $\begin{array}{c}\text { 2SLS } \\
\text { (2) }\end{array}$ & $\begin{array}{l}\text { OLS } \\
\text { (3) }\end{array}$ & $\begin{array}{c}2 S L S \\
(4)\end{array}$ & $\begin{array}{c}\text { OLS } \\
(5)\end{array}$ & 2SLS \\
\hline $\begin{array}{l}\text { Inherited Land } \\
\text { (Acres) }\end{array}$ & $\begin{array}{l}-0.001 * \\
(0.001)\end{array}$ & $\begin{array}{c}-0.007 * * * \\
(0.002)\end{array}$ & $\begin{array}{l}-0.001 \\
(0.001)\end{array}$ & $\begin{array}{l}-0.000 \\
(0.003)\end{array}$ & $\begin{array}{c}-0.002 * * * \\
(0.000)\end{array}$ & $\begin{array}{l}-0.004 \\
(0.003)\end{array}$ \\
\hline Mean of Dep. Var. & 0.054 & 0.054 & 0.095 & 0.095 & 0.062 & 0.062 \\
\hline First Stage F-statistic & - & 125.952 & - & 125.952 & - & 125.952 \\
\hline $\mathrm{N}$ & 4809 & 4809 & 4809 & 4809 & 4809 & 4809 \\
\hline No. of Siblings FE & $\bar{Y}$ & $\bar{Y}$ & $\bar{Y}$ & $\bar{Y}$ & $\bar{Y}$ & $\bar{Y}$ \\
\hline Family Land FE & $\mathrm{Y}$ & $\mathrm{Y}$ & $\mathrm{Y}$ & $\mathrm{Y}$ & $\mathrm{Y}$ & $\mathrm{Y}$ \\
\hline District FE & $\mathrm{Y}$ & $\mathrm{Y}$ & $\mathrm{Y}$ & $\mathrm{Y}$ & $\mathrm{Y}$ & $\mathrm{Y}$ \\
\hline
\end{tabular}

Notes:

This table reports estimates of the long-term effect of inherited land on non-farm business ownership, holding a salaried position and non-agricultural wage work. Columns 1, 3 and 5 report OLS coeffiient estimates while columns 2, 4 and 6 report 2SLS estimates. The sample are Hindu male household heads whose parents owned land in the 1999 ARIS-REDS's survey. The data is at the household head-level. The dependent variable in all columns correspond to the primary status reported by the respondent in the REDS survey. In column 1 and 2 if the primary status is non-farm business then it is coded as 1, in cols 3 and 4 if it is a salaried position and if cols 5 and 6 if it is non-agriculural wage work. All specifications include district fixed effects ( 99 dummies), fixed effects for family landholdings (0-80+ acres, 5 acre intervals, 15 dummies) and the number of siblings (14 dummies). The excluded group are heads who are only children from West Godavari district in Andhra Pradesh with family landholdings between 0-5 acres. The instrument specfication used is Predicted Share $=1 /(1+$ Brothers). The F-stat reported is the partial F-statistic for the instrument(s) ( CraggDonald Wald F-statistic). Robust standard errors are given in parentheses, asterisks denote significance: * $\mathrm{p}<0.10, * * \mathrm{p}<0.05, * * *$ $\mathrm{p}<0.01$. Standard errors are clustered at the family level for sibling-level regressions. Data Source: ARIS-REDS Dataset. 
APPENDIX C1: ROBUSTNESS OF 2SLS ESTIMATES TO ALTERNATIVE INSTRUMENT SPECIFICATIONS

\begin{tabular}{|c|c|c|c|c|c|}
\hline $\begin{array}{l}\text { Instrument } \\
\text { Specification }\end{array}$ & $\begin{array}{c}\text { Linear (No. of } \\
\text { Brothers) } \\
\text { (1) }\end{array}$ & $\begin{array}{c}\text { Predicted Share } \\
(2) \\
\end{array}$ & $\begin{array}{l}\text { Predicted Land } \\
\text { (3) }\end{array}$ & $\begin{array}{l}\text { Log(Predicted } \\
\text { Land }) \\
(4) \\
\end{array}$ & $\begin{array}{c}\text { Non-Parametric } \\
\text { (Brother } \\
\text { Dummies) } \\
(5)\end{array}$ \\
\hline \multicolumn{6}{|c|}{ Panel A. Dependent Variable: Non-Ag Occupation (Binary) } \\
\hline $\begin{array}{l}\text { Inherited Land } \\
\text { (Acres) }\end{array}$ & $\begin{array}{c}-0.020 * * * \\
(0.005)\end{array}$ & $\begin{array}{c}-0.018 * * * \\
(0.005)\end{array}$ & $\begin{array}{l}-0.002 \\
(0.002)\end{array}$ & $\begin{array}{c}-0.042 * * * \\
(0.007)\end{array}$ & $\begin{array}{c}-0.017 * * * \\
(0.005)\end{array}$ \\
\hline $\begin{array}{l}\text { Mean of Dep. Var. } \\
\text { First Stage F-Statistic } \\
\mathrm{N}\end{array}$ & $\begin{array}{c}0.298 \\
128.137 \\
4809\end{array}$ & $\begin{array}{c}0.298 \\
125.952 \\
4809\end{array}$ & $\begin{array}{c}0.298 \\
101.458 \\
4809\end{array}$ & $\begin{array}{c}0.298 \\
141.607 \\
4809\end{array}$ & $\begin{array}{c}0.298 \\
22.433 \\
4809\end{array}$ \\
\hline \multicolumn{6}{|c|}{ Panel B. Dependent Variable: Yearly Household Consumption, Log (Rs.) } \\
\hline $\begin{array}{l}\text { Inherited Land } \\
\text { (Acres) }\end{array}$ & $\begin{array}{c}0.032 * * * \\
(0.006)\end{array}$ & $\begin{array}{c}0.027 * * * \\
(0.006)\end{array}$ & $\begin{array}{c}0.022 * * * \\
(0.003)\end{array}$ & $\begin{array}{c}0.052 * * * \\
(0.007)\end{array}$ & $\begin{array}{c}0.031 * * * \\
(0.006)\end{array}$ \\
\hline $\begin{array}{l}\text { Mean of Dep. Var. } \\
\text { First Stage F-Statistic } \\
\mathrm{N}\end{array}$ & $\begin{array}{c}10.442 \\
128.137 \\
4809\end{array}$ & $\begin{array}{c}10.442 \\
125.952 \\
4809\end{array}$ & $\begin{array}{c}10.442 \\
101.458 \\
4809\end{array}$ & $\begin{array}{c}10.442 \\
141.607 \\
4809\end{array}$ & $\begin{array}{c}10.442 \\
22.433 \\
4809\end{array}$ \\
\hline $\begin{array}{l}\text { No. of Siblings FE } \\
\text { Family Land FE } \\
\text { District FE }\end{array}$ & $\begin{array}{l}\mathrm{Y} \\
\mathrm{Y} \\
\mathrm{Y}\end{array}$ & $\begin{array}{l}\mathrm{Y} \\
\mathrm{Y} \\
\mathrm{Y}\end{array}$ & $\begin{array}{l}\mathrm{Y} \\
\mathrm{Y} \\
\mathrm{Y}\end{array}$ & $\begin{array}{l}\mathrm{Y} \\
\mathrm{Y} \\
\mathrm{Y}\end{array}$ & $\begin{array}{l}\mathrm{Y} \\
\mathrm{Y} \\
\mathrm{Y}\end{array}$ \\
\hline
\end{tabular}

Notes:

This table tests the robustness of 2SLS estimates of the long-term effect of inherited land on occupational choice and household consumption to alternative specifications of the instrument. The sample is restricted to Hindu male household heads whose parents owned land in the 1999 ARIS-REDS's survey. The data is at the household head level. Column 1 reports 2SLS estimates with the instrument specified as the (linear) number of brothers, in column 2 it is 'Predicted Share' $=1 /(1+$ Brothers $)$, in column 3 it is 'Predicted Land' = Family Land $/(1+$ Brothers $)$, in column 4 it is Log(Predicted Land), and in column 5 it is the a set of dummies for the number of brothers ( 8 dummies in total, I report the coefficients for up to 5 brothers which account for $98.11 \%$ of sample). The dependent variable in Panel A is Non-Ag occupation and is defined by the primary status reported by the respondent in the REDS survey. The variable is coded as 0 if this is selfcultivation or agricultural labor and 1 otherwise. The dependent variable Panel B is the natural logarithm of yearly household consumption. This includes food and non-food items, and values home production at village-specific market prices. All specifications include district fixed effects ( 99 dummies), fixed effects for family landholdings $(0-80+$ acres, 5 acre intervals, 15 dummies) and the number of siblings (14 dummies). The excluded group are heads who are only children from West Godavari district in Andhra Pradesh with family landholdings between 0-5 acres. The F-stat reported is the partial F-statistic for the instrument(s) (Cragg-Donald Wald F-statistic). Robust standard errors are given in parentheses, asterisks denote significance: $* \mathrm{p}<0.10, * * \mathrm{p}<0.05, * * * \mathrm{p}<0.01$. Data Source: ARIS-REDS Dataset. 


\section{Appendix C2: Reduced Form Simulations of Selective}

\section{Migration}

A potential selection concern arises from the fact that all surveyed households in the REDS dataset reside in rural areas. As such, a subset of individuals who migrate to urban areas after inheriting land are not sampled and may compromise the estimated relationships. For example, if these 'missing migrants' inherited small amounts of land and subsequently took up non-agricultural jobs in urban areas, I would underestimate the negative effect of land. Conversely, if the migrants inherited large amounts of land and then took up a nonagricultural occupation, I would overestimate the negative effect of land. Given the nature of the REDS data these migrants would need to result from the movement of entire families to urban areas; household heads report the location of their siblings irrespective of where they reside. While nationally representative estimates of the extent of permanent rural-urban family migration are not available, studies suggest this form of migration is extremely rare in India (Munshi and Rosenzweig, 2007). In the REDS sibling data, just 1.1\% of 16,130 male siblings have migrated to urban areas. Foster and Rosenzweig (2007) estimate the individual rural to urban migration rate for males aged 15-24 for each decade between 1961 and 2001 using the corresponding Indian censuses. ${ }^{68}$ They find that migration rates vary from $3 \%$ to $5 \%$ for each of the decades between 1961-2001, suggesting very limited migration even when considering the movement of individuals rather than entire families.

The estimated negative relationships between inherited land and both migration and entering non-agricultural work suggest that migrants would need to have large landholdings in order to overturn the estimates. It is worth noting that this is a hypothetical at odds with the estimated negative causal effect of inherited land on urban migration. Additionally, these landholdings cannot be so large that they have little influence on the 2SLS estimates.

\footnotetext{
${ }^{68}$ They assume that mortality does not vary differentially between urban and rural areas and suggest that if anything local amenities may be better in urban areas leading to an overestimate of the out-migration rate.
} 
The latter restriction is a result of the nonlinearity of the estimated relationship between inherited land and both occupational choice and migration as suggested by Panel B of Table 3 and Panel A \& B of Figure 4 and the weighting structure of 2SLS with covariates. The estimated slopes are especially negative and precise for inheritances of up to 4 acres of land. However, for those inheriting more than 4 acres, the qualitative nature of the relationship is unclear and the estimates are imprecise. As such, migrants with very large landholdings would be included in covariate-specific LATE's (i.e. the 2SLS estimate computed for subsets of the sample covariates) that are qualitatively different in sign from the overall LATE and have little variation in the instrument as a consequence of having few observations and are therefore not heavily weighted in the overall LATE.

These restrictions suggest that migrants whose parents owned intermediate amounts of land - i.e. covariate values that occur frequently in the data and drive the negative estimated relationships - would be the most likely to overturn the reduced form estimates. Having specified family landholdings, the sibling sex composition of migrants would determine their inherited landholdings. Appendix C2 models the sibling sex composition of migrants as resulting from a series of draws from a binomial distribution and estimates the reduced form for occupational choice - all urban migrants are assumed to hold non-agricultural occupations - under varying probabilities of success (i.e. the probability of drawing a male sibling). These simulations quantify how skewed the sibling sex composition of migrants would need to be to overturn the reduced form estimate. ${ }^{69}$

The simulations add observations to mimic a 10\% rural to urban migration rate: the census-based individual urban migration rate for the three decades preceding the REDS survey. In both panels the reduced form estimate from the main specification is indicated by the horizontal red line, while the grey area shows the $95 \%$ confidence interval for the simulated reduced form coefficients. Panel A shows the estimated reduced form coefficients when migrants are assumed to to have the most frequent sibling and family land combination: 3

\footnotetext{
${ }^{69}$ If the probability of drawing a male sibling is zero, all the respondents siblings will be sisters and he will inherit all his parents land.
} 
siblings and parents who own 5 acres of land, while in Panel B they are assumed to have parents who own 40 acres land (95th percentile for family landholdings). ${ }^{70}$ As suggested by the discussion above, migrants with smaller family landholdings (Panel A) have a greater influence on the reduced form estimates than those with large landholdings (Panel B). However, even in Panel B the probability of a male sibling occurring would need to be less than 0.17 - the point at which the red line leaves the confidence interval - in order to overturn the reduced form relationship. This is substantially lower than the biological probability of a male and the observed ratio of brothers to siblings for rural to urban migrants in the IHDS data: 0.53 .

\footnotetext{
${ }^{70}$ While respondents with an extremely small number of siblings may be the most likely to be missing from the REDS survey, these covariate values occur very infrequently in the data and are given little weight in the 2SLS estimates because they also permit little variation in the first stage fitted values. Only children make up just $5.7 \%$ of the sample.
} 


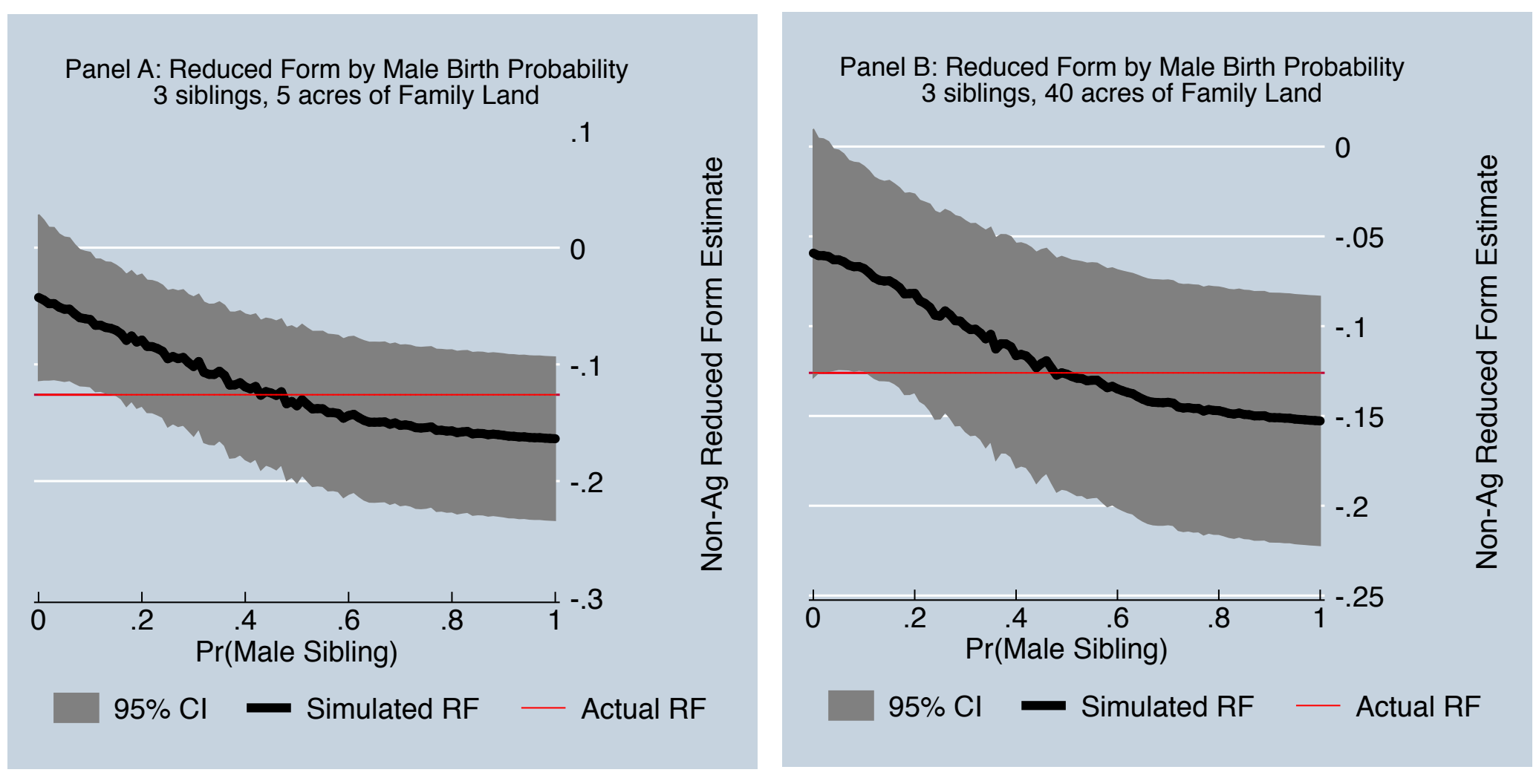

Notes:

These figures plot the results of simulations intended to test the robustness of the reduced form relationship for non-agricultural occupation to selective family migration. Both panels add the simulated data to the main sample of Hindu male household heads whose parents owned land in the 1999 wave of the ARIS-REDS dataset. Both panels assume a family migration rate of $10 \%$. Panel A assumes the migrants have 3 siblings and their parents own 5 acres of land, while Panel B assumes that the migrants have 3 siblings and their parents own 40 acres of family land. Where $\mathrm{N}$ is the number of siblings assigned to the migrants, the program takes $\mathrm{N}$ draws from a binomial distribution with a success $\mathrm{K}$ for each of the migrants. $\mathrm{K}$ is varied from 0 to 1 in intervals of 0.01 and the reduced form relationship is estimated for each of these values and plotted with the $95 \%$ confidence interval using robust standard errors. The red line in each panel shows the estimated reduced form estimate with the main specification: -0.126 . In each case the missing migrants are assumed to come from Allahabad District in Uttar Pradesh. All specifications include district fixed effects ( 99 dummies), fixed effects for family landholdings (0-80+ acres, 5 acre intervals, 15 dummies) and the number of siblings (14 dummies). The excluded group are heads who are only children, from West Godavari district in Andhra Pradesh with family landholdings between 0-5 acres. Data Source: ARIS-REDS Dataset. 


\begin{tabular}{|c|c|c|c|c|c|c|}
\hline Dependent Variable & $\begin{array}{c}\text { Mean/ S.D. } \\
\text { Full Sample } \\
(1)\end{array}$ & $\begin{array}{l}\text { Effect of I } \\
2 \text { siblings } \\
(2)\end{array}$ & $\begin{array}{c}\text { 2SLS } \\
\text { herited Lan } \\
3 \text { siblings } \\
(3)\end{array}$ & $\begin{array}{l}\text { Estimates E } \\
\text { on Outomc } \\
4 \text { siblings } \\
\text { (4) }\end{array}$ & $\begin{array}{l}\text { mates } \\
\text { by Sibling } \\
5 \text { siblings } \\
(5)\end{array}$ & $\begin{array}{l}\text { ohort Size } \dagger \\
\text { Full Sample } \\
(6)\end{array}$ \\
\hline \multicolumn{7}{|c|}{ Panel A. Dependent Variable: Non-Agricultural Occupation } \\
\hline $\begin{array}{l}\text { Inherited Land } \\
\text { (Acres) }\end{array}$ & $\begin{array}{c}0.298 \\
(0.458)\end{array}$ & $\begin{array}{l}-0.007 \\
(0.013)\end{array}$ & $\begin{array}{c}-0.043 * * * \\
(0.014)\end{array}$ & $\begin{array}{l}-0.010 \\
(0.012)\end{array}$ & $\begin{array}{l}-0.021 * \\
(0.011)\end{array}$ & $\begin{array}{c}-0.018 * * * \\
(0.005)\end{array}$ \\
\hline $\mathrm{N}$ & 4809 & 729 & 811 & 777 & 726 & 4809 \\
\hline \multicolumn{7}{|c|}{ Panel B. Dependent Variable: Log(Household Consumption) } \\
\hline $\begin{array}{l}\text { Inherited Land } \\
\text { (Acres) }\end{array}$ & $\begin{array}{l}10.442 \\
(0.614)\end{array}$ & $\begin{array}{c}0.032 * * \\
(0.016)\end{array}$ & $\begin{array}{c}0.005 \\
(0.017)\end{array}$ & $\begin{array}{c}0.006 \\
(0.014)\end{array}$ & $\begin{array}{c}0.053 * * * \\
(0.011)\end{array}$ & $\begin{array}{c}0.027 * * * \\
(0.006)\end{array}$ \\
\hline $\mathrm{N}$ & 4809 & 729 & 811 & 777 & 726 & 4809 \\
\hline No. of Siblings FE & - & $\mathrm{N}$ & $\mathrm{N}$ & $\mathrm{N}$ & $\mathrm{N}$ & $\mathrm{Y}$ \\
\hline Family Land FE & - & $\mathrm{Y}$ & $\mathrm{Y}$ & $\mathrm{Y}$ & $\mathrm{Y}$ & $\mathrm{Y}$ \\
\hline District FE & - & $\mathrm{Y}$ & $\mathrm{Y}$ & $\mathrm{Y}$ & $\mathrm{Y}$ & $\mathrm{Y}$ \\
\hline
\end{tabular}

Notes:

I his table presents 2 SLS estımates tor the ettect of inherited land on occupational choice and household consumption by sibling cohort size. The sample is restricted to Hindu male household heads whose parents owned land in the 1999 ARIS-REDS's survey. The data is at the household head level. †Columns 2-6 report the 2SLS coefficient on inherited landholdings. Columns 2-5 report the coefficient for household heads with varying numbers of siblings, while Column 6 includes all household heads. Non-Ag occupation is defined by the primary status reported by the respondent in the REDS survey. The variable is coded as 0 if this is self-cultivation or agricultural labor and 1 otherwise. $\log$ (Household Consumption) is the natural logarithm of yearly household consumption which includes food and non-food items, and values home production at village-specific market prices. All specifications include district fixed effects (99 dummies), fixed effects for family landholdings (0-80+ acres, 5 acre intervals, 15 dummies) and the number of siblings (14 dummies). The excluded group are heads who are only children, from West Godavari district in Andhra Pradesh with family landholdings between 0-5 acres. Brothers are defined as male siblings who grew up to at least the age of 10 . Results are robust to alternative definitions and using ever born siblings. Robust standard errors are given in parentheses, asterisks denote significance: ${ }^{*} \mathrm{p}<0.10, * *$ $\mathrm{p}<0.05, * * * \mathrm{p}<0.01$. Data Source: ARIS-REDS Dataset. 


\section{Appendix C4: Robustness to Differential Stopping Rules}

Nnother threat to the conditional independence of the instrument stems from son-preferring, differential stopping behavior (SP-DSB). On average, women in India are more likely to belong to families with a larger number of siblings and have less education on average (Jensen, 2003. While the inclusion of sibling fixed effects takes care of some of these concerns, it may still be the case that families with different fertility constraints or preferences end up with a similar number of children, resulting in an apples to oranges comparison in the regressions of interest.

The use of an alternative instrument, which only uses variation resulting from the sex composition of siblings older than the respondent, partially addresses this concern. This variation is by definition unaffected by differential stopping behavior as these siblings are born prior to the respondent. When used together with birth order fixed effects for the respondent, the estimates in column (4) of appendix C4 are very similar to those in the main specification. In the case of occupational choice the coefficient is not precisely estimated and this may once again be due to a much weaker first stage (two-thirds of F-statistic from main specification).

In order to further alleviate this concern, column (5) reports the estimates for the subset of respondents whose youngest sibling is female. By definition, such families could not have engaged in son-preferring differential stopping behavior. These families are, therefore, more likely to have exhausted a fertility constraint. When fertility constraints are binding it is more likely that sibling sex composition reflects the biological probability that children are born to a specific sex. Once again, the estimated coefficients are comparable to those obtained in the main specification in column (1) and in this case they are also precisely estimated. 
APPENDIX C4: ROBUSTNESS OF 2SLS ESTIMATES TO SEX SELECTIVE FERTILITY PREFERENCES

\begin{tabular}{|c|c|c|c|c|c|}
\hline \multirow[b]{2}{*}{ Specification } & \multirow[b]{2}{*}{$\begin{array}{l}\text { Main } \\
\text { (1) } \\
\end{array}$} & \multicolumn{2}{|c|}{ Sex Selection Tests } & \multicolumn{2}{|c|}{ Differential Stopping Tests } \\
\hline & & $\begin{array}{c}\text { Exact } \\
\text { Permuation } \\
\text { (2) }\end{array}$ & $\begin{array}{c}\text { Sibling Spacing } \\
\text { Controls } \\
(3) \\
\end{array}$ & (4) & $\begin{array}{c}\text { Youngest } \\
\text { Sibling is } \\
\text { Female } \\
\text { (5) }\end{array}$ \\
\hline \multicolumn{6}{|c|}{ Panel A. Dependent Variable: Non-Ag Occupation (Binary) } \\
\hline $\begin{array}{l}\text { Inherited Land } \\
\text { (Acres) }\end{array}$ & $\begin{array}{c}-0.018 * * * \\
(0.005)\end{array}$ & $\begin{array}{c}-0.029 * * * \\
(0.007)\end{array}$ & $\begin{array}{c}-0.018 * * * \\
(0.005)\end{array}$ & $\begin{array}{l}-0.008 \\
(0.008)\end{array}$ & $\begin{array}{c}-0.018 * * * \\
(0.006)\end{array}$ \\
\hline Mean of Dep. Var. & 0.298 & 0.298 & 0.298 & 0.298 & 0.292 \\
\hline $\mathrm{N}$ & 4809 & 4809 & 4809 & 4809 & 1947 \\
\hline \multicolumn{6}{|c|}{ Panel B. Dependent Variable: Log(Household Consumption) } \\
\hline $\begin{array}{l}\text { Inherited Land } \\
\text { (Acres) }\end{array}$ & $\begin{array}{c}0.027 * * * \\
(0.006)\end{array}$ & $\begin{array}{c}0.016 * * \\
(0.008)\end{array}$ & $\begin{array}{c}0.027 * * * \\
(0.006)\end{array}$ & $\begin{array}{c}0.049 * * * \\
(0.010)\end{array}$ & $\begin{array}{l}0.035 * * * \\
(0.008)\end{array}$ \\
\hline Mean of Dep. Var. & 10.442 & 10.442 & 10.442 & 10.442 & 10.455 \\
\hline F-stat (First Stage) & 125.952 & 89.579 & 132.955 & 83.447 & 59.106 \\
\hline $\mathrm{N}$ & 4809 & 4809 & 4809 & 4809 & 1947 \\
\hline No. of Siblings FE & $\mathrm{Y}$ & $\mathrm{Y}$ & $\mathrm{Y}$ & $\mathrm{Y}$ & $\mathrm{Y}$ \\
\hline Family Land FE & $\mathrm{Y}$ & $\mathrm{Y}$ & $\mathrm{Y}$ & $\mathrm{Y}$ & Y \\
\hline District FE & $\mathrm{Y}$ & $\mathrm{Y}$ & $\mathrm{Y}$ & Y & Y \\
\hline Sibling Sex Permuation FE & $\mathrm{N}$ & $\mathrm{Y}$ & $\mathrm{N}$ & $\mathrm{N}$ & $\mathrm{N}$ \\
\hline Sibling Spacing FE & $\mathrm{N}$ & $\mathrm{N}$ & $\mathrm{Y}$ & $\mathrm{N}$ & $\mathrm{N}$ \\
\hline Instruments & Pred Share & Pred Share & Pred Share & Prior Bros & Pred Share \\
\hline Sample & All & All & All & All & Last Born Sis \\
\hline
\end{tabular}

Notes:

This table tests the robustness of 2SLS estimates of the long-term effect of inherited land on occupational choice and household consumption to sex selection and son-preferring differential stopping behavior, both of which stand to violate the conditional independence assumption of the instrument. The sample is restricted to Hindu male household heads whose parents owned land in the 1999 ARIS-REDS's survey. The data is at the household head level. Column 1 reports 2SLS estimates for the main specification used in Table 3. Column 2 includes fixed effects for the exact permutation of the sex of siblings born prior to the head of the household (i.e. MMF, FFM etc.. ) and includes 223 dummy variables. Column 3 includes fixed effects for the average birth spacing (in years) between siblings (0-10+ years, 6 month intervals, 18 dummies. Column 4 uses the sex composition of siblings born prior to the head as an instrument for inherited landholdings (i.e. number of brothers). This specification also includes a set of 10 dummy variables for the birth order of the head of the household. Column 5 limits the sample to the subset of heads whose youngest sibling is female. This is under the assumption that those families who stop on a girl are more likely to have satisfied a resource constraint than stopped because of son-preferring differential stopping behavior. The dependent variable in Panel A is Non-Ag occupation and is Non-Ag occupation is defined by the primary status reported by the respondent in the REDS survey. The variable is coded as 0 if this is selfcultivation or agricultural labor and 1 otherwise. The dependent variable in Panel B is the natural logarithm of yearly household consumption. This includes food and non-food items, and values home production at villagespecific market prices. All specifications include district fixed effects ( 99 dummies), fixed effects for family landholdings ( $0-80+$ acres, 5 acre intervals, 15 dummies) and the number of siblings ( 14 dummies). The excluded group are heads who are only children from West Godavari district in Andhra Pradesh with family landholdings between 0-5 acres. The F-stat reported is the partial F-statistic for the instrument(s) ( Cragg-Donald Wald Fstatistic). Robust standard errors are given in parentheses, asterisks denote significance: ${ }^{*} \mathrm{p}<0.10,{ }^{* *} \mathrm{p}<0.05$, $* * *$ $\mathrm{p}<0.01$. Data Source: ARIS-REDS Dataset. 


\begin{tabular}{|c|c|c|c|c|c|c|c|c|}
\hline \multirow[b]{2}{*}{ Dependent Variable } & \multicolumn{2}{|c|}{ First Stage } & \multirow{2}{*}{$\begin{array}{c}\text { Main } \\
\text { Non-Ag } \\
\text { Occupation } \\
\text { (Binary) } \\
(3) \\
\end{array}$} & \multirow{2}{*}{$\begin{array}{l}\text { Education } \\
\text { Controls } \\
\text { Non-Ag } \\
\text { Occupation } \\
\text { (Binary) } \\
(4) \\
\end{array}$} & \multirow{2}{*}{$\begin{array}{c}\text { Dowry } \\
\text { Controls } \\
\text { Non-Ag } \\
\text { Occupation } \\
\text { (Binary) } \\
(5) \\
\end{array}$} & \multirow{2}{*}{$\begin{array}{c}\text { Main } \\
\text { HH } \\
\text { Consumption } \\
\text { Log(Rs.) } \\
\text { (6) }\end{array}$} & \multirow{2}{*}{$\begin{array}{c}\text { Education } \\
\text { Controls } \\
\text { HH } \\
\text { Consumption } \\
\text { Log(Rs.) } \\
(7) \\
\end{array}$} & \multirow{2}{*}{$\begin{array}{c}\text { Dowry } \\
\text { Controls } \\
\text { HH } \\
\text { Consumption } \\
\text { Log(Rs.) } \\
(8) \\
\end{array}$} \\
\hline & $\begin{array}{c}\text { Education } \\
\text { (Years) } \\
(1)\end{array}$ & $\begin{array}{c}\text { Net Dowry } \\
\text { (Binary) } \\
(2)\end{array}$ & & & & & & \\
\hline \multicolumn{9}{|c|}{ Panel A : First Stage Regressions } \\
\hline Predicted Share & $\begin{array}{c}1.397 * * * \\
(0.386)\end{array}$ & $\begin{array}{c}-0.087 * * * \\
(0.031)\end{array}$ & - & - & - & - & - & - \\
\hline $\begin{array}{l}\text { Mean of Dep. Var. } \\
\text { F-stat (First Stage) }\end{array}$ & $\begin{array}{c}5.847 \\
13.119\end{array}$ & $\begin{array}{l}0.698 \\
8.091\end{array}$ & - & - & - & - & - & - \\
\hline $\mathrm{N}$ & 4809 & 4809 & - & - & - & - & - & - \\
\hline \multicolumn{9}{|c|}{ Panel B. 2SLS Estimates } \\
\hline $\begin{array}{l}\text { Inherited Land } \\
\text { (Acres) }\end{array}$ & - & - & $\begin{array}{c}-0.018 * * * \\
(0.005)\end{array}$ & $\begin{array}{c}-0.015^{* * *} \\
(0.005)\end{array}$ & $\begin{array}{c}-0.021 * * * \\
(0.005)\end{array}$ & $\begin{array}{c}0.027 * * * \\
(0.006)\end{array}$ & $\begin{array}{c}0.028 * * * \\
(0.006)\end{array}$ & $\begin{array}{c}0.024 * * * \\
(0.006)\end{array}$ \\
\hline $\begin{array}{l}\text { Mean of Dep. Var. } \\
\text { F-stat (First Stage) }\end{array}$ & - & - & $\begin{array}{c}0.298 \\
125.952\end{array}$ & $\begin{array}{c}0.298 \\
124.544\end{array}$ & $\begin{array}{c}0.298 \\
118.234\end{array}$ & $\begin{array}{c}10.442 \\
125.952\end{array}$ & $\begin{array}{c}10.442 \\
118.234\end{array}$ & $\begin{array}{c}10.442 \\
124.544\end{array}$ \\
\hline $\mathrm{N}$ & - & - & 4809 & 4809 & 4809 & 4809 & 4809 & 4809 \\
\hline No. of Siblings FE & $\overline{\mathrm{Y}}$ & $\mathrm{Y}$ & $\mathrm{Y}$ & $\mathrm{Y}$ & $\mathrm{Y}$ & $\mathrm{Y}$ & $\mathrm{Y}$ & $\overline{\mathrm{Y}}$ \\
\hline Family Land FE & $\mathrm{Y}$ & $\mathrm{Y}$ & $\mathrm{Y}$ & $\mathrm{Y}$ & $\mathrm{Y}$ & $\mathrm{Y}$ & $\mathrm{Y}$ & $\mathrm{Y}$ \\
\hline District FE & Y & $\mathrm{Y}$ & $\mathrm{Y}$ & Y & Y & Y & $\mathrm{Y}$ & Y \\
\hline Education FE & $\mathrm{N}$ & $\mathrm{N}$ & $\mathrm{N}$ & Y & $\mathrm{N}$ & $\mathrm{N}$ & Y & $\mathrm{N}$ \\
\hline Net Dowry FE & $\mathrm{N}$ & $\mathrm{N}$ & $\mathrm{N}$ & $\mathrm{N}$ & $\mathrm{Y}$ & $\mathrm{N}$ & $\mathrm{N}$ & $\mathrm{Y}$ \\
\hline
\end{tabular}

Notes:

This table tests the robustness of 2SLS estimates of the long-term effect of inherited land on occupational choice and household consumption to controls for net dowry receipts and education controls. The sample is restricted to Hindu male household heads whose parents owned land in the 1999 ARISREDS's survey. The data is at the household head level. Column 1 in Panel A reports the first stage for years of education using the 'predicted share' instrument. Column 2 in Panel A reports the first stage for net dowry. This variable coded as 1 if the net dowry receipts of the household are above median. The latter is calculated as the net sum of all dowry payments and receipts for the parents which are reported for each sibling of the head of the household. 37\% of the sample do not report paying or receiving dowry. Columns 3-5 in Panel B report the 2SLS estimates of inherited land on nonagricultural occupation. Non-Ag occupation is defined by the primary status reported by the respondent in the REDS survey. The variable is coded as 0 if this is self-cultivation or agricultural labor and 1 otherwise. Columns 6-8 in Panel B report the 2SLS estimate of inherited land on the log of household consumption. This includes food and non-food items, and values home production at village-specific market prices. Columns 4 and 7 include fixed effects for years of education of the household head, 12 dummies, 1 year intervals. Columns 5 and 8 include fixed effects for the net dowry receipts. This calculates the net difference between dowry received and spent by the head's parents for all siblings, and then creates 19 dummies (Rs. $-50,000-$ Rs. $50,000+$, Rs. 5000 intervals). All specifications include district fixed effects (99 dummies), fixed effects for family landholdings (0-80+ acres, 5 acre intervals, 15 dummies) and the number of siblings (14 dummies). The excluded group are heads who are only children from West Godavari district in Andhra Pradesh with family landholdings between 0-5 acres. The F-stat reported is the partial F-statistic for the instrument(s) ( Cragg-Donald Wald Fstatistic) Robust standard errors are given in parentheses, asterisks denote significance: ${ }^{*} \mathrm{p}<0.10, * * \mathrm{p}<0.05$, $* * * \mathrm{p}<0.01$. Data Source: ARIS-REDS Dataset. 


\section{APPENDIX C6: ROBUSTNESS OF 2SLS ESTIMATES TO ALTERNATIVE DEFINITIONS OF OCCUPATIONAL CHOICE AND BIRTH ORDERS CONTROLS}

\begin{tabular}{|c|c|c|c|c|c|c|}
\hline Specification & Main & $\begin{array}{c}\text { Definition } \\
\text { Change } \\
\end{array}$ & Main & $\begin{array}{c}\text { Eldest Son } \\
\text { Control } \\
\end{array}$ & Main & $\begin{array}{c}\text { Eldest Son } \\
\text { Control } \\
\end{array}$ \\
\hline \multirow{4}{*}{ Dependent Variable } & Non-Ag & Non-Ag & Non-Ag & Non-Ag & Household & Household \\
\hline & Occupation & Occupation & Occupation & Occupation & Consumption & Consumption \\
\hline & Binary & Binary & Binary & Binary & $\log ($ Rs. $)$ & $\log ($ Rs. $)$ \\
\hline & $(1)$ & $(2)$ & (3) & (4) & $(5)$ & $(6)$ \\
\hline Land & $-0.018 * * *$ & $-0.016 * * *$ & -0.004 & -0.012 & $0.037 * * *$ & $0.055 * * *$ \\
\hline (Acres) & $(0.005)$ & $(0.004)$ & $(0.006)$ & $(0.007)$ & $(0.007)$ & $(0.014)$ \\
\hline \multirow[t]{2}{*}{ First Born } & - & - & $0.195^{* * *}$ & $0.173^{* * *}$ & $0.216^{* * *}$ & $0.296^{* * *}$ \\
\hline & & & $(0.058)$ & $(0.059)$ & $(0.065)$ & $(0.084)$ \\
\hline \multirow[t]{2}{*}{ Land*First Born } & - & - & $-0.045^{* * *}$ & $-0.036^{* *}$ & $-0.033 * *$ & $-0.052 * *$ \\
\hline & & & $(0.014)$ & $(0.015)$ & $(0.016)$ & $(0.022)$ \\
\hline Age FE & $\mathrm{N}$ & $\mathrm{N}$ & Y & $\mathrm{Y}$ & $\mathrm{Y}$ & $\mathrm{Y}$ \\
\hline No. of Siblings FE & Y & $\mathrm{Y}$ & $\mathrm{Y}$ & $\mathrm{Y}$ & $\mathrm{Y}$ & $\mathrm{Y}$ \\
\hline Family Land FE & $\mathrm{Y}$ & Y & Y & Y & Y & Y \\
\hline District FE & Y & $\mathrm{Y}$ & Y & Y & Y & Y \\
\hline Eldest Son Dummy & $\mathrm{N}$ & $\mathrm{N}$ & $\mathrm{N}$ & $\mathrm{Y}$ & $\mathrm{N}$ & $\mathrm{Y}$ \\
\hline Mean of Dep. Var. & 0.298 & 0.265 & 0.298 & 0.265 & 10.442 & 10.442 \\
\hline F-stat (First Stage) & 128.137 & 125.952 & 26.667 & 26.667 & 26.667 & 29.852 \\
\hline $\mathrm{N}$ & 4809 & 4809 & 4809 & 4809 & 4809 & 4809 \\
\hline Non-Ag Definition & Primary Status & Majority Income & Primary Status & Primary Status & - & - \\
\hline Eldest Son Dummy & No & No & No & Yes & No & Yes \\
\hline
\end{tabular}

Notes:

This table tests the robustness of 2SLS estimates of the effect of inherited land on occupational choice to an alternative definition of occupational choice (Columns 1 and 2). This table also tests the robustness of heterogeneous effects by birth order to additional controls. The sample is restricted to Hindu male household heads whose parents owned land in the 1999 ARIS-REDS's survey. The data is at the household head level. Column 1 reports the 2SLS estimates using the main specification with the instrument as predicted share. In column 1, Non-Ag occupation is defined as the 'primary status' reported by the respondent in the REDS survey. The variable is coded as 0 if this is self-cultivation or agricultural labor and 1 otherwise. Column 2 reports estimates using the definition of Non-Ag occupation as 'majority income'. This is defined as whether the majority of the respondent's income comes from activities not related to self-cultivation or agricultural labor using income data. Columns 3-6 report the 2SLS coefficients on inherited land, first-born - a dummy coded as 1 if the household head was the first-born child in his family - and their interaction. The two endogenous variables are instrumented with two instruments : Predicted Share $=(1 / 1+$ Brothers $)$ and the interaction between Predicted Share and First Born. These coefficients are from the main specification. Columns 4 and 6 include a dummy variable coded as 1 if the respondent is the eldest son but not the first born in the family. The dependent variable in columns 3 and 4 is Non-Ag occupation and is defined by the primary status reported by the respondent in the REDS survey. The variable is coded as 0 if this is self-cultivation or agricultural labor and 1 otherwise. The dependent variable columns 5 and 6 is the natural logarithm of yearly household consumption. This includes food and non-food items, and values home production at village-specific market prices. All specifications include district fixed effects (99 dummies), fixed effects for family landholdings (0-80+ acres, 5 acre intervals, 15 dummies) and the number of siblings ( 14 dummies). The excluded group are heads who are only children from West Godavari district in Andhra Pradesh with family landholdings between 0-5 acres. The F-statistic reported is the partial F-statistic for the instrument(s) ( Cragg-Donald Wald F-statistic). Robust standard errors are given in parentheses, asterisks denote significance: ${ }^{*} \mathrm{p}<0.10,{ }^{*} \mathrm{p}<0.05,{ }^{*} * \mathrm{p}<0.01$. Data Source: ARIS-REDS Dataset. 


\section{Appendix C7: Post Reform Areas and Urban Areas}

\section{Reforms to the Hindu Succession Act}

Reforms to inheritance laws giving women equal inheritance rights were passed in Kerala (1976), Andhra Pradesh (1986), Tamil Nadu (1989), Maharashtra (1994) and Karnataka

(1994). In the main sample, there are 1,506 respondents residing in these states, 473 of whom inherited land after the reforms. Column (1) in Appendix C7 shows that the reforms significantly reduce the influence of sibling sex composition on inherited landholdings, consistent with Deininger et al. (2013). However, sibling sex composition still has an appreciable effect on the inheritance of land, consistent with the primacy of customs over law. The point estimate for consumption in column (7) is qualitatively different for post-reform respondents, but imprecisely estimated. In contrast, the effects for non-agricultural occupation does not vary substantially, but the null cannot be rejected in the post-reform sample.

\section{Urban versus Rural Households}

The absence of urban agricultural land among urban households means that the effect of sibling sex composition cannot, by definition, operate through this channel in urban areas. In addition to the absence of agricultural land, urban households are more likely to have recourse to professional legal services, rather than have property disputes settled by male-biased village councils (Rao, 2007). Taken together, this suggests that sibling sex composition may have a smaller role in influencing the size of one's inheritance. The IHDS contains a sample of 16,205 households across rural and urban India for whom sibling sex composition data is available. Column (4) in Appendix C7 tests whether the reduced form effects for household consumption vary across urban and rural areas. The point estimate for consumption in urban areas is very different in magnitude to rural areas and the null hypothesis cannot be rejected in the urban sample. 


\section{APPENDIX C7: THE FIRST STAGE AND REDUCED FORM EFFECTS FOR REFORM AREAS}

AND URBAN AREAS

\begin{tabular}{|c|c|c|c|c|}
\hline \multirow[b]{2}{*}{ Dependent Variable } & \multicolumn{3}{|c|}{ Before vs. After Reform } & \multirow[b]{2}{*}{$\begin{array}{c}\text { Rural vs. Urban } \\
\text { HH } \\
\text { Consumption } \\
\text { Log (Rs.) } \\
(4) \\
\end{array}$} \\
\hline & $\begin{array}{c}\text { Inherited Land } \\
\text { (Acres) } \\
(1)\end{array}$ & $\begin{array}{l}\text { Non-Ag } \\
\text { Occupation } \\
\text { (Binary) } \\
(2) \\
\end{array}$ & $\begin{array}{c}\mathrm{HH} \\
\text { Consumption } \\
\text { Log (Rs.) } \\
(3) \\
\end{array}$ & \\
\hline Predicted Share & $\begin{array}{c}7.674 * * * \\
(1.327)\end{array}$ & $\begin{array}{l}-0.067 \\
(0.062)\end{array}$ & $\begin{array}{c}0.350 * * * \\
(0.082)\end{array}$ & $\begin{array}{c}0.082 * * * \\
(0.028)\end{array}$ \\
\hline $\begin{array}{l}\text { Dummy for Restricted Sample } \\
\text { (Post-Reform/Urban) }\end{array}$ & $\begin{array}{c}0.789 \\
(0.559)\end{array}$ & $\begin{array}{c}0.044 \\
(0.047)\end{array}$ & $\begin{array}{c}0.011 \\
(0.053)\end{array}$ & $\begin{array}{c}0.278 * * * \\
(0.024)\end{array}$ \\
\hline Predicted Share*Dummy & $\begin{array}{l}-2.054 * \\
(1.229)\end{array}$ & $\begin{array}{c}0.007 \\
(0.090)\end{array}$ & $\begin{array}{l}-0.124 \\
(0.095)\end{array}$ & $\begin{array}{l}-0.060 \\
(0.037)\end{array}$ \\
\hline Family Land FE & $\mathrm{Y}$ & $\mathrm{Y}$ & $\mathrm{Y}$ & $\mathrm{N}$ \\
\hline No. of Siblings FE & $\mathrm{Y}$ & Y & $\mathrm{Y}$ & $\mathrm{Y}$ \\
\hline District FE & $\mathrm{Y}$ & $\mathrm{Y}$ & $\mathrm{Y}$ & $\mathrm{Y}$ \\
\hline Father's Occupation FE & $\mathrm{N}$ & $\mathrm{N}$ & $\mathrm{N}$ & $\mathrm{Y}$ \\
\hline Age FE & $\mathrm{N}$ & $\mathrm{N}$ & $\mathrm{N}$ & $\mathrm{Y}$ \\
\hline Education FE & $\mathrm{N}$ & $\mathrm{N}$ & $\mathrm{N}$ & $\mathrm{Y}$ \\
\hline Can Reject Null Hypothesis in & Yes & No & Yes & No \\
\hline Depvar Mean & 3.746 & 0.253 & 10.399 & 10.575 \\
\hline F-statistic & 22.404 & - & - & - \\
\hline $\mathrm{N}$ & 1506 & 1506 & 1506 & 16205 \\
\hline Data Source & & IS-REDS, 19 & Wave & IHDS, 2004-05 \\
\hline
\end{tabular}

Notes:

This table tests whether the first stage and reduced form effects for non-agricultural occupation and consumption vary differentially within states, before and after progressive reforms to patrilineal laws were instituted. It also tests whether the reduced form effect on consumption varies among urban and rural areas. These tests are intended to provide support for the exclusion restriction assumption. The data in Columns 1-3 the sample is restricted to Hindu male household heads whose parents owned land in the 1999 ARIS-REDS's survey in states that experienced reforms for the Hindu Succession Act. In Column 4 the data used is from the Indian Human Development Survey and includes all Hindu household heads in rural and urban areas. In Columns 1-3 'Dummy for Restricted Sample' is a dummy variable coded as 1 if the respondent became the head of the household after reforms to inheritance laws and 0 if before. In column 4 , it is a dummy coded as 1 if the head resides in an urban area and 0 if the head resides in a rural area. Reforms to the Hindu Succession Act occurred in Kerala (1976), Andhra Pradesh (1986), Tamil Nadu (1989), Maharashtra (1994) and Karnataka (1994), where the parentheses indicate the date of the reform The dependent variable in Column 1 is inherited land. The dependent variable in Column 2 is whether the head held a non-agricultural occupation, defined by the primary status reported by the respondent in the REDS survey. The variable is coded as 0 if this is self-cultivation or agricultural labor and 1 otherwise. In Column 3 and 4 the dependent variable is the natural logarithm of yearly household consumption. This includes food and non-food items, and values home production at village-specific market prices. Specifications 1-3 include district fixed effects (99 dummies), fixed effects for family landholdings ( $0-80+$ acres, 5 acre intervals, 15 dummies and the number of siblings (14 dummies). Specification 4 includes district fixed effects ( 99 dummies), number of head's siblings (19 dummies), fixed effects for head's education (0-15 years, 1 year intervals, 14 dummies), age of the household head (20-100, 5 year intervals, 15 dummies), father's occupation ( 89 dummies), and father's education (0-15, years, 1 year intervals, 14 dummies). Parent's landholdings are not reported in the IHDS data. The F-stat reported is the partial F-statistic for the instrument(s) (Cragg-Donald Wald F-statistic). Data Source: ARISREDS Dataset. 


\section{APPENDIX C8: SENSITIVITY OF REDUCED FORM ESTIMATES TO VIOLATION OF EXCLUSION RESTRICTION}

\section{$\underline{\text { Panel A }}$}

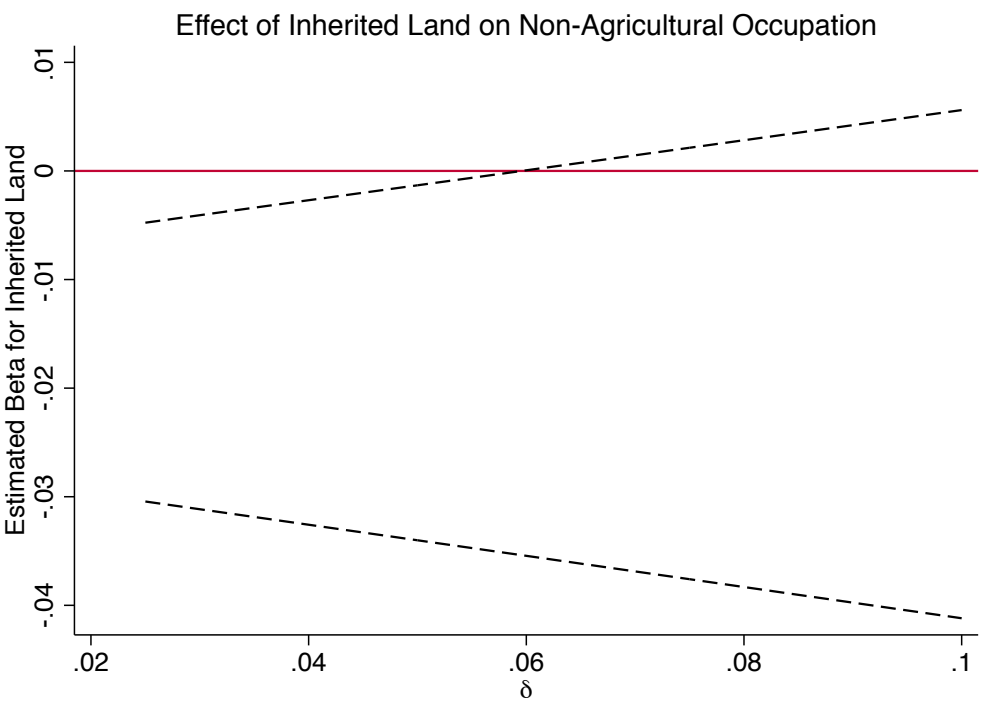

Panel B

Effect of Inherited Land on Log(Household Consumption)

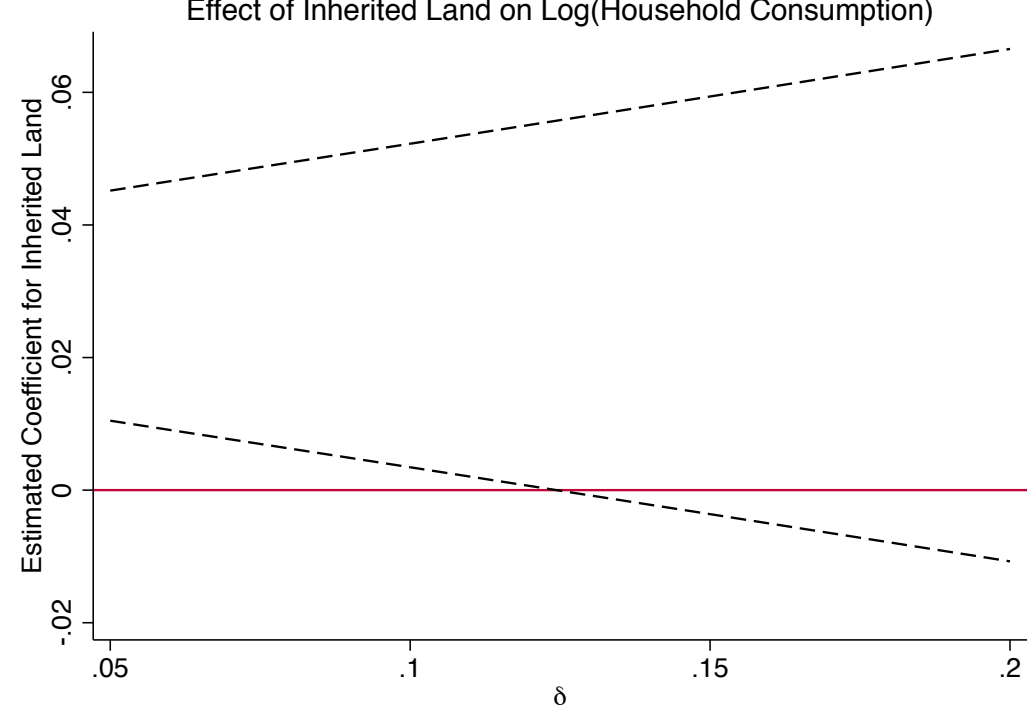

Notes:

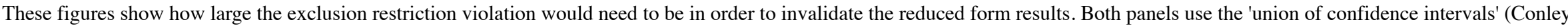
et al. 2012) approach to estimate the size of the exclusion restriction needed to violate the reduced form for non-agricultural occupation (Panel A) and household consumption (Panel B). The dashed lines plot the union of confidence intervals where the parameter $\delta$ varies the possible values of $\gamma$ the size of the exclusion restriction violation such that $\gamma \in[-2 \delta, 2 \delta]$. These figures were produced using the 'plausexog' code produced by Damian Clarke (2014). Data Source: ARIS-REDS Dataset. 